Argumentação e prova na matemática escolar

Aline dos Reis Matheus

São Paulo, junho de 2016 


\title{
Argumentação e prova na matemática escolar
}

\author{
Aline dos Reis Matheus \\ DISSERTAÇÃO APRESENTADA \\ AO \\ INSTITUTO DE MATEMÁTICA E ESTATÍSTICA \\ DA \\ UNIVERSIDADE DE SÃo PAUlo \\ PARA \\ OBTENÇÃO DO TÍTULO \\ $\mathrm{DE}$ \\ Mestre em Ensino de Matemática
}

Programa: Mestrado Profissional em Ensino de Matemática

Orientadora: $\operatorname{Prof}^{\mathrm{a}} \operatorname{Dr}^{\mathrm{a}}$ Cláudia Cueva Candido

Durante o desenvolvimento deste trabalho, a autora recebeu auxílio financeiro da CAPES, por meio do projeto 20698 OBEDUC - Ensino de Matemática na Escola Elementar 


\section{Argumentação e prova na matemática escolar}

Esta versão da dissertação contém correções e alterações sugeridas pela

Comissão Julgadora durante a defesa da versão original do trabalho, realizada em 19/04/2016. Uma cópia da versão original está disponível no Instituto de Matemática e Estatística da Universidade de São Paulo.

Comissão Julgadora:

- Prof $^{a}$ Dr $^{a}$ Cláudia Cueva Candido - IME-USP

- Prof. Dr. Nílson José Machado - FE-USP

- Prof. Dr. Saddo Ag Almouloud - PUC-SP 
Dedico os esforços empreendidos neste trabalho às jovens mulheres-irmãs-de-peito que não tiveram a mesma sorte que eu.

E dedico todo o amor que depositei aqui ao meu avô João, que se foi antes que essa minha sorte fosse validada pela vida. 


\section{Agradecimentos}

Quero expressar minha imensa gratidão a todas as pessoas e instituições que, direta ou indiretamente, contribuíram para a realização deste trabalho.

Em primeiro lugar, a minha orientadora, Cláudia Cueva Candido, pela parceria de muito tempo, pelo carinho e, especialmente, pela coragem intelectual de me permitir seguir por mares nunca antes navegados por nós.

A Coordenadoria de Aperfeiçoamento de Pessoal de Ensino Superior (CAPES), pelo apoio financeiro concedido por meio do projeto OBEDUC - Ensino de matemática na escola elementar.

Aos professores Nilson José Machado e Saddo Ag Almouloud, pelas valiosas sugestões na qualificação.

A todos os membros da equipe do CAEM, com quem há anos venho partilhando reflexões sobre o ensino de matemática. Em especial, aos membros da diretoria - Ana Paula Jahn, Cláudia Cueva, Cristina Cerri, Martha Salerno Monteiro e Raul Ferraz -, pelo estímulo e por viabilizarem minha dedicação a este programa de mestrado.

À coordenação e aos professores do MPEM, com quem tive o privilégio de estudar durante esta jornada - Bárbara Corominas, César Polcino, Cristina Cerri, Lisbeth Cordani, Marcos Magalhães, Maria Cristina Bonomi, Martha Salerno e Ricardo Bianconi.

À professora Iole de Freitas Druck, pela inspiração que o curso de Lógica proporcionou, pela condução do grupo de estudo sobre Balacheff e pela crítica ao texto submetido ao exame de qualificação. Principalmente, agradeço-lhe uma aula-visita (ou seria uma visita-aula?), que, para mim, demonstra seu desprendimento e sua generosidade.

Às professoras que participaram do projeto OBEDUC - Ensino de matemática na escola Elementar, por terem gentilmente aceitado responder ao questionário, ceder entrevistas e fornecer material para nossa investigação.

A Vânia Andrade Luz, pela ajuda com algumas traduções do francês e, claro, por tudo o que partilhou comigo quando trabalhamos juntas.

À Confraria de Textos, pela cuidadosa revisão do texto final.

Agradeço ainda às centenas (talvez milhares) de pessoas que passaram pela minha vida profissional ao longo dos últimos anos: colegas professores, gestores, professores em formação, colegas formadores e, claro, alunos. Todos deixaram um pouco de suas dúvidas, certezas, aceitações, rejeições, insights, conhecimentos, satisfações, dificuldades, potencialidades, interesses...

Aos amigos queridos sem os quais a vida ficaria muito sem graça - tão sem graça que não haveria motivação para escrever dissertações.

A meus pais, Ana Maria e Márcio, especialmente pelo amor e por todo o estímulo a meu crescimento, inclusive intelectual. A obviedade do fato não o torna menos importante e belo: é nas escolhas de vocês que começa toda a minha jornada.

A meus avós, Carmem e João, pelo colo amoroso, sempre disponível e seguro. A minhas irmãs, Roberta e Natalie, por serem, cada uma a seu modo, minhas amadas companheiras nesta vida. A toda a família - Kakau, Tata, Ricardo, Allan, Emmanuelle, Rebeca, Marcos, Nathan e Paulinha -, pela rede de apoio, carinho e proteção que me permitiu superar os períodos difíceis que coincidiram com a realização deste trabalho.

Um agradecimento mais que especial a meu marido, Caio, pelo amor, pela alegria e pela paciência - apoio fundamental para que eu me lance em qualquer desafio. 


\section{Resumo}

MATHEUS, A. R. Argumentação e prova na matemática escolar. 2016. 145 f. Dissertação (Mestrado) - Instituto de Matemática e Estatística, Universidade de São Paulo, São Paulo, 2016.

Este trabalho revisa e problematiza a usual associação entre a matemática escolar e o desenvolvimento do raciocínio lógico, introduzindo a argumentação e a prova em matemática como um elo de tal associação. Assim, desenvolve-se uma investigação tanto teórica quanto de campo, visando compreender por que, embora central na matemática acadêmica, a prova é tão pouco explorada na matemática escolar. A investigação teórica reviu diversas referências, em geral oriundas da Educação Matemática, mas também da História da Matemática, com vistas a: (1) compreender o papel de destaque da prova no contexto atual da Matemática, a partir do entrelaçamento entre a noção de demonstração e o próprio desenvolvimento dessa ciência; (2) discutir aspectos conceituais e epistemológicos da prova matemática que podem contribuir para um trabalho significativo com o tema na educação básica; e (3) compreender as razões da ausência de um trabalho significativo com a prova matemática na educação básica do Brasil nas últimas décadas. A investigação de campo complementa a investigação teórica apresentando um estudo de caso sobre conhecimentos, crenças e concepções de um pequeno grupo de professoras de matemática da educação básica a respeito do raciocínio lógico e da prova matemática. Essas investigações permitiram concluir que são diversas as causas do suposto abandono do trabalho com a prova matemática na educação básica, entre as quais destacamos a falta de uma discussão aprofundada sobre o tema na formação inicial de professores e a presença de práticas de ensino de matemática pautadas numa concepção tecnicista.

Palavras-chave: Prova matemática. Demonstração. Raciocínio lógico. Ensino de matemática. Concepções de professores. 


\begin{abstract}
MATHEUS, A. R. Argumentation and proof in school mathematics. 2016. $145 \mathrm{f}$. Dissertação (Mestrado) - Instituto de Matemática e Estatística, Universidade de São Paulo, São Paulo, 2016.

In this dissertation, we review and problematize the usual association between school mathematics and the development of logical reasoning, introducing the proof in mathematics as a link of this association. Therefore we conducted both theoretical research and field research, in order to understand why the mathematical proof, although central to academic mathematics, is so little emphasized in school mathematics. In theoretical research, we reviewed several references, usually arising from the Mathematics Education, but also from the History of Mathematics, in order to: (1) understand the important role of proof in the current context of mathematics, from the entanglement between the notion of demonstration and even the development of this science; (2) discuss conceptual and epistemological aspects of the mathematical proof that can contribute to meaningful work with this theme in basic education; and (3) understand the reasons for the absence of meaningful work with mathematical proof in basic education in Brazil in recent decades. The field research complements the theoretical research presenting a case study on knowledge, beliefs and conceptions of a small group of mathematics teachers of basic education about logical reasoning and mathematical proof. These investigations allowed us to conclude that there are various causes for the alleged abandonment of work in mathematical proof in basic education, among which we highlight: the absence of thorough discussion of this topic school teacher education and the presence of current practice of a technical approach to math teaching.
\end{abstract}

Keywords: Mathematics proof. Logical reasoning. Mathematics teaching. Teacher's conceptions. 


\section{Lista de quadros}

Quadro 1 PISA 2012: Escala de Proficiência de Matemática ................................................... 10

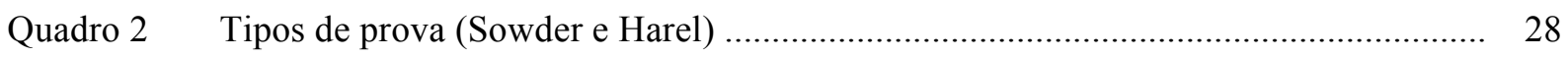

Quadro 3 Das provas pragmáticas às demonstrações .............................................................. 30

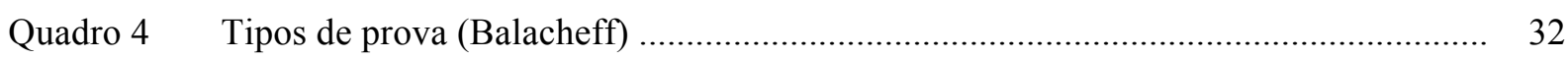

Quadro 5 Comparação entre a tipologia de provas de Balacheff e a de Sowder e Harel ........... 32

Quadro $6 \quad$ Soma de números pares (duas provas) .................................................................... 37

\section{Lista de figuras}

Figura 1 Argumentação em matemática ……................................................................... 26

Figura 2 Problema da não conservação de área ………......................................................... 34

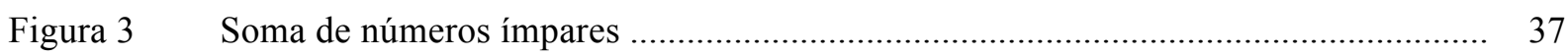

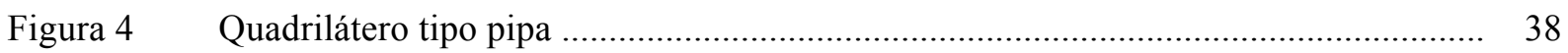

Figura 5 Comparação entre pipa côncava e convexa ………….............................................. 38

Figura 6 Funções da prova na matemática escolar ................................................................. 41

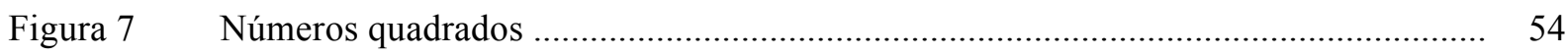

Figura 8a Construção do número quadrado seguinte ……….................................................. 55

Figura 8b Construção do número quadrado seguinte …………............................................... 55

Figura $8 \mathrm{c} \quad$ Construção do número quadrado seguinte ................................................................ 55

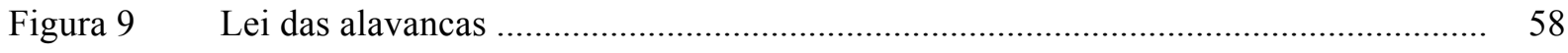

Figura 10a Método mecânico para determinação do volume da esfera ....................................... 59

Figura 10b Método mecânico para determinação do volume da esfera ....................................... 59

Figura 10c Método mecânico para determinação do volume da esfera .......................................... 60

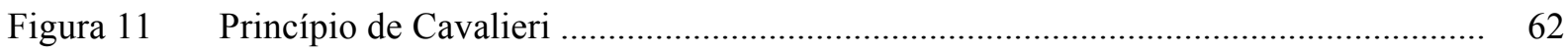




\section{Sumário}

Introdução 9

Parte 1 - INVESTIGAÇÃO TEÓRICA

1 Explicar, provar, demonstrar: argumentar em matemática 20

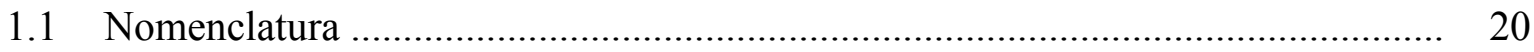

1.2 Tipos de prova na matemática escolar ............................................................... 27

1.3 Funções da prova em matemática ....................................................................... 33

2 O papel da demonstração na Matemática 42

2.1 Breve panorama histórico da noção de demonstração na Matemática ................. 43

2.2 O problema da validação em episódios da História da Matemática ...................... 53

2.2.1 O conhecimento empírico dos pitagóricos .............................................. 53

2.2.2 Descoberta e validação em Arquimedes ................................................. 56

2.2.3 Eficácia versus rigor em Cavalieri ..................................................... 61

3 O lugar reservado à prova na matemática escolar 64

3.1 A prova matemática na educação básica brasileira: do destaque ao "ostracismo" .... 67

3.2 A prova matemática na formação inicial dos professores de matemática ............. 75

3.3 O que dizem (e o que não dizem) os PCN acerca da prova ................................. 78

Parte 2 - INVESTIGAÇÃO DE CAMPO 82

4 A investigação de campo $\quad 83$

4.1 O projeto Ensino de Matemática na Escola Elementar ....................................... 83

4.2 Metodologia de pesquisa ........................................................................... 84

4.2.1 Os sujeitos da pesquisa ................................................................... 86

4.2.2 Instrumentos de coleta de evidências ...................................................... 89

4.2.3 O caso em estudo ......................................................................... 93

5 Análise das evidências coletadas 97

5.1 Conhecimentos, concepções e crenças associadas ao raciocínio lógico ............... 98

5.2 Relação entre raciocínio lógico e prova matemática ........................................... 106

5.3 Dificuldades para o trabalho com a prova matemática ...................................... 110

5.3.1 Dificuldades relativas ao conhecimento matemático ............................. 111

5.3.2 Dificuldades relativas a crenças e concepções sobre a prova matemática na educação básica ............................................................................... 117

5.3.3 Dificuldades relativas a crenças e concepções ligadas à autoridade docente ou à autonomia intelectual dos alunos 


\title{
Introdução
}

Nosso interesse pelo tema da argumentação e da prova na matemática escolar nasceu da percepção de uma aparente contradição. Nossa experiência como professora e formadora de professores de matemática ao longo dos últimos treze anos tem mostrado que boa parte dos colegas destacam o desenvolvimento do raciocínio lógico como um dos principais objetivos do ensino da matemática escolar. Entre muitos professores, parece haver certo nível de concordância tácita de que, ainda que alguns conteúdos da matemática escolar atual sejam dificilmente aplicáveis - o que, na maior parte dos casos, parece ser visto como negativo -, eles poderiam ser "redimidos" por concorrer para ensinar a raciocinar logicamente. No entanto, nossa concepção de raciocínio lógico está intimamente ligada à argumentação, que, em matemática, se expressa pela relação dinâmica entre conjecturas, provas e refutações. Assim, essa contradição aparente residiria no fato de que, apesar desse objetivo tão propalado, conjecturar, provar e refutar resultados matemáticos não parecem ser comumente propostas aos alunos nas aulas de matemática da educação básica. Nossa percepção a respeito coincide, por exemplo, com a de Nasser e Tinoco (2001, p. 1):

\begin{abstract}
Após o abandono da matemática moderna, com o movimento de retorno às bases da matemática, o que se viu foi o abandono total do raciocínio dedutivo e das demonstrações. Embora "desenvolver o raciocínio lógico" seja um dos objetivos incluídos nos planejamentos de quase todos os professores de matemática [...] a realidade hoje mostra que a maioria dos alunos não está aprendendo a pensar e raciocinar quando estuda os diversos conteúdos de matemática. Se pensarmos um pouco na natureza das aulas de matemática da maioria das escolas brasileiras, chegamos a uma constatação: os jovens não estão habituados a pensar e comunicar suas ideias. Isto é, na maioria das escolas, o aluno ainda é levado a resolver uma lista enorme de exercícios repetitivos, que para ele não têm significado algum. Não vendo uma ligação significativa do conteúdo com sua vida, o aluno apenas repete os modelos dados pelo professor ou aplica fórmulas, e em nenhum momento é questionado ou levado a pensar por que a resposta é aquela, ou mesmo se a resposta é coerente, plausível com a pergunta do problema.
\end{abstract}

Uma evidência indireta que também corrobora nossa percepção de que a argumentação em matemática não vem sendo trabalhada adequadamente nas escolas é o resultado brasileiro no Programme for International Student Assessment (PISA), uma avaliação em larga escala desenvolvida e coordenada pela Organização para Cooperação e Desenvolvimento Econômico (OCDE). O PISA, que avaliou o letramento matemático dos estudantes brasileiros de 15 anos de idade em 2003 e em 2012, inclui habilidades relativas ao raciocínio e à argumentação. Na edição de 2003, 75,2\% dos estudantes avaliados ficaram nos níveis 1 ou 2 
da escala de proficiência, que vai de 1 a 6 . Na edição de 2012, a situação melhorou, mas ainda ficou longe do desejável: 67,1\% ficaram nos mesmos níveis 1 ou 2 .

O Quadro 1, que está contido na Matriz de Avaliação do PISA 2012 e foi extraído da página virtual do Instituto Nacional de Estudos e Pesquisas Educacionais Anísio Teixeira (INEP, 2013), descreve os seis níveis de proficiência considerados na avaliação.

Quadro 1 - PISA 2012: Escala de Proficiência de Matemática

\begin{tabular}{cl}
\hline nível $\begin{array}{c}\text { limite inferior } \\
\text { de pontos }\end{array}$ & \multicolumn{1}{c}{ características das atividades } \\
\hline & $\begin{array}{l}\text { No Nível 6, os estudantes são capazes de conceituar, generalizar e utilizar } \\
\text { informações com base em suas investigações e em modelagem de }\end{array}$ \\
& situações-problema complexas. Conseguem estabelecer ligações entre \\
& diferentes fontes de informações e representações, e de transitar entre elas \\
& com flexibilidade. Os estudantes situados neste nível utilizam pensamento e \\
& raciocínio matemáticos avançados. São capazes de associar sua percepção e
\end{tabular}

No Nível 5, os estudantes são capazes de desenvolver modelos para situações complexas e trabalhar com eles, identificando restrições e especificando hipóteses. Conseguem selecionar, comparar e avaliar estratégias adequadas de resolução de problemas para lidar com problemas

$5 \quad 607,0$ complexos relacionados a esses modelos. Os estudantes situados neste nível são capazes de trabalhar estrategicamente, utilizando habilidades de pensamento e raciocínio abrangentes e bem desenvolvidas, representações conectadas de maneira adequada, caracterizações simbólicas e formais, e percepção relativa a essas situações. São capazes de refletir sobre suas ações e de formular e comunicar suas interpretações e seu raciocínio.

No Nível 4, os estudantes podem trabalhar de maneira eficaz com modelos explícitos para situações concretas complexas, que podem envolver restrições ou exigir formulação de hipóteses. São capazes de selecionar e integrar diferentes representações, inclusive representações simbólicas, relacionando-as diretamente a aspectos de situações da vida real. Nesses contextos, os estudantes situados neste nível são capazes de utilizar habilidades desenvolvidas e raciocínio, com flexibilidade e alguma percepção. São capazes de construir e comunicar explicações e argumentos com base em interpretações, argumentos e ações. 


\begin{tabular}{|c|c|c|}
\hline nível & $\begin{array}{l}\text { limite inferior } \\
\text { de pontos }\end{array}$ & características das atividades \\
\hline 3 & 482,4 & $\begin{array}{l}\text { No Nível 3, os estudantes são capazes de executar procedimentos descritos } \\
\text { com clareza, inclusive aqueles que exigem decisões sequenciais. } \\
\text { Conseguem selecionar e aplicar estratégias simples de resolução de } \\
\text { problemas. Os estudantes situados neste nível são capazes de interpretar e } \\
\text { utilizar representações baseadas em diferentes fontes de informação e de } \\
\text { raciocinar diretamente a partir delas. Conseguem desenvolver } \\
\text { comunicações curtas que relatam interpretações, resultados e raciocínio. }\end{array}$ \\
\hline 2 & 420,1 & $\begin{array}{l}\text { No Nível 2, os estudantes são capazes de interpretar e reconhecer situações } \\
\text { em contextos que não exigem mais do que inferência direta. São capazes de } \\
\text { extrair informações relevantes de uma única fonte e de utilizar um modo } \\
\text { simples de representação. Os estudantes situados neste nível conseguem } \\
\text { empregar algoritmos, fórmulas, procedimentos ou convenções de nível } \\
\text { básico. São capazes de raciocinar diretamente e de fazer interpretações } \\
\text { literais dos resultados. }\end{array}$ \\
\hline 1 & 357,8 & $\begin{array}{l}\text { No Nível 1, os estudantes são capazes de responder a questões definidas } \\
\text { com clareza, que envolvem contextos conhecidos, nas quais todas as } \\
\text { informações relevantes estão presentes. Conseguem identificar informações } \\
\text { e executar procedimentos rotineiros de acordo com instruções diretas em } \\
\text { situações explícitas. São capazes de executar ações óbvias e dar } \\
\text { continuidade imediata ao estímulo dado. }\end{array}$ \\
\hline \multicolumn{2}{|c|}{ Abaixo de $1 b$} & A OCDE não especifica as habilidades envolvidas. \\
\hline
\end{tabular}

Nossa percepção da contradição entre discurso e prática - intenção e ação -, no que tange à relação entre matemática escolar e desenvolvimento do raciocínio lógico, moldou nosso quadro de pesquisa. Mas, desde o início, dissemos que a contradição é apenas aparente, porque pode residir no significado atribuído à expressão "raciocínio lógico", de uso corrente e muitas vezes pouco preciso.

Neste trabalho, usaremos o termo raciocínio como propõe Balacheff (1987): atividade intelectual (implícita, na maior parte do tempo) de manipulação de dados para a produção de novas informações. Nesses termos, observamos que, em sua complexidade, a atividade matemática demanda diversas formas de raciocínio: por exemplo, o lógico dedutivo, o lógico indutivo, o não determinístico, o analógico e o geométrico-espacial. Entre os citados, usualmente dois incluem o adjetivo lógico, ambos relativos a argumentação e inferência. $\mathrm{O}$ raciocínio lógico dedutivo, que é descrito pela Lógica Aristotélica, permite manipular informações gerais de modo a obter uma conclusão particular, como acontece nos silogismos clássicos: 
Para que um raciocínio dedutivo seja válido (ou correto), a veracidade das premissas deve garantir a veracidade da conclusão. Embora seja mais importante que o conteúdo para a validade, a forma não é suficiente para a veracidade das premissas. Ou seja, o conceito de validade, que se aplica ao raciocínio como um todo, é diferente do conceito de veracidade. Isso significa que, ainda que o raciocínio seja válido, se partirmos de premissas falsas, podemos obter conclusões falsas. Por outro lado, uma vez que se admita que as premissas são verdadeiras, esse tipo de raciocínio - quando válido - conduz à certeza da veracidade da conclusão.

Já num raciocínio lógico indutivo, não tem sentido falar em validade, mas apenas em plausibilidade, uma vez que esse tipo de raciocínio opera por generalizações como:

O Sol tem nascido todos os dias.

Portanto, o Sol nascerá amanhã.

Assim, num um raciocínio lógico indutivo, a veracidade das premissas não garante a veracidade da conclusão, mas a observação de padrões generalizáveis deve conduzir a conclusões plausíveis.

Tanto o raciocínio lógico dedutivo quanto o indutivo (assim como outros) podem servir a processos de inferência, validação, explicação e mesmo de descoberta de resultados matemáticos, ainda que com diferentes níveis de confiabilidade. Portanto, eles estão na base da argumentação e da prova em matemática.

Supomos que nem todos os professores de matemática compartilhem nossa concepção a respeito do que é raciocínio lógico e do que é raciocinar em matemática, e uma das questões que pretendemos investigar nesta pesquisa é:

- Como os professores de matemática entendem a relação entre matemática e raciocínio lógico? Essa relação envolve, em alguma medida, as noções de argumentação e prova?

Tendo a relação entre o raciocínio lógico e a matemática como pano de fundo, passamos a nos interessar especificamente pelo problema da prova em matemática em geral e, particularmente, na educação básica. Mais uma vez, nossas concepções prévias moldam nosso quadro de investigação, fazendo com que nos debrucemos sobre uma segunda aparente contradição. Entendemos que a prova (e mais especificamente a demonstração, como veremos 
mais adiante) está no cerne da atividade em Matemática ${ }^{1}$ desde há muito tempo. Muito oportunamente, Garnica (1996, p. 9-10) ilustra esse entendimento:

A importância da prova rigorosa para o fazer em Matemática pode ser atestada, a princípio, por alguns matemáticos da envergadura do grupo Bourbaki ("Depuis les Grecs, qui dit mathématique dit démonstration; certains doutent même qu'il se trouve, en dehors des mathématiques, des démonstration au sens précis et rigoureux que ce mot a reçu des Grecs"). ${ }^{2}$ Não bastando isso, o discurso e a atividade cotidianos da prática científica da Matemática afirmam reconhecer a prova como elemento central no desenvolvimento do que se conhece por Matemática.

Assim, a importância tão marcada da prova na matemática acadêmica (ou científica) parece em contradição com a pouca importância que, segundo nossa experiência, vem tendo na matemática escolar brasileira.

Diversas pesquisas corroboram nossa observação de que a prova matemática não tem sido abordada na educação básica brasileira. Num projeto realizado na Pontifícia Universidade Católica de São Paulo (PUC SP), por exemplo, fez-se uma investigação com professoras de matemática da educação básica na qual elas deveriam procurar demonstrações matemáticas em livros didáticos. A pesquisa revelou a dificuldade das professoras com o conceito de demonstração, como explicam Almouloud e outros (2008, p. 231-232):

A partir dos comentários feitos pelas professoras e pela escolha do "exemplo" de demonstração, tornou-se evidente que, para elas, a demonstração em matemática está associada a algo que evidencie o que se está pretendendo ensinar, como, por exemplo, o caso da adição e subtração de números relativos por meio das balas colocadas em potes de vidro. Para elas, demonstração é uma contextualização, no sentido de que, ao se criar uma situação-problema com o objetivo de tornar compreensível para os alunos um teorema ou propriedade, esse teorema ou propriedade já estará demonstrado. Tais afirmações nos mostram, também, a grande preocupação atual de se dar um sentido prático a tudo o que se faz em matemática, transparecendo que só tem valor o que se pode aplicar de imediato numa situação cotidiana. O compreensível passa a ser apenas aquilo que pode ser usado no dia a dia, isto é, um conhecimento de uso imediato.

Ou seja, para as professoras citadas nesse estudo, uma demonstração é uma espécie de "mostração", o que indica que o significado específico da palavra tal como é usada no

\footnotetext{
${ }^{1}$ Nesta dissertação, designamos a ciência com inicial maiúscula e matemática, com minúscula, tem um sentido mais amplo, podendo se referir a práticas nem sempre idênticas às de uma comunidade matemática acadêmica ou científica.

2 "Desde os gregos, quem diz matemática diz demonstração; alguns duvidam até mesmo que seja possível encontrar demonstrações, fora da matemática, no sentido preciso e rigoroso que foi dado pelos gregos a essa palavra" (GARNICA, 1996, p. 9-10, tradução nossa).
} 
contexto da Matemática não está incorporado em seu repertório. A noção de demonstração empregada pelas professoras está ligada à preocupação de tornar inteligível o funcionamento de um teorema ou propriedade, mas não chega a problematizar sua validade ou as razões de sua validade. A análise dos pesquisadores a respeito da forma como as professoras usam essa palavra também revela que parece predominar a preocupação de mostrar a aplicabilidade da matemática, em detrimento de desenvolver a compreensão das formas de produção do conhecimento matemático (que incluem a prova).

Por um lado, entendemos que a matemática escolar é tributária da Matemática, especialmente no sentido de que um dos papéis da escola é inserir os jovens em alguns aspectos da cultura e da tradição (no caso, da cultura e da tradição matemática). Sendo assim, ao excluir da matemática escolar um elemento tão essencial para a Matemática, parece-nos que a escola não cumpre adequadamente seu papel. Por outro lado, não vemos razão para uma identificação completa entre os objetivos e as práticas da matemática acadêmica com os objetivos e as práticas da matemática escolar. Segundo Moreira e David (2005, p. 10), a distinção entre matemática escolar e matemática acadêmica:

[...] permite contrastar os interesses, os saberes e os significados atribuídos tanto pela comunidade científica em relação à Matemática quanto pelos professores e alunos no processo de ensinar e aprender matemática na escola básica. Tal análise não busca, de forma alguma, aprofundar o fosso ainda presente entre essas duas formas de conhecimento matemático. Ao contrário, pretende estabelecer uma interlocução cultural mais criativa, dinâmica e contributiva para ambas; assim, pode superar tanto a tendência endógena das disciplinas escolares de se constituírem pela/na/para a escola, mantendo certa independência das disciplinas acadêmicas, como observa André Chervel, quanto à perspectiva colonizadora do mundo acadêmico sobre $\mathrm{o}$ mundo da escola, a qual consiste em propor e controlar "o que" e "como" os professores devem ensinar.

Neste trabalho, optamos por investigar a matemática acadêmica e a matemática escolar, a fim de perscrutar interlocuções possíveis no que tange à argumentação e à prova, e, a partir da verificação de que existe uma fissura entre esses dois tipos de prática matemática, buscamos nossas principais referências teóricas na Educação Matemática - campo eminentemente interdisciplinar, que se situa na interface dessas duas práticas matemáticas e que, por isso, nos parece fecundo para tratar do problema.

Antes de descrever os rumos que demos à investigação para enfrentá-lo, convém ressaltar que a importância do assunto vai além de introduzir os alunos da educação básica na cultura e na tradição matemática. (Essa redução poderia soar como um "saudosismo 
formalista", para aqueles que não se aprofundarem na leitura integral do trabalho, e esse não é absolutamente o caso.) Entendemos que o desenvolvimento do raciocínio lógico nas aulas de matemática - tal como o concebemos, por meio de atividades envolvendo argumentação e prova - é importante para que a escola exerça importantes funções formativas. Os Parâmetros Curriculares Nacionais (PCN, 1998, p. 27, grifo nosso), por exemplo, explicitam a contribuição da matemática na formação do cidadão, para que possa lidar com as exigências da vida moderna:

Parece haver um razoável consenso de que, para responder a essas exigências, é preciso elevar o nível da educação de toda a população. Desse modo, não cabe ao ensino fundamental preparar mão de obra especializada, nem se render, a todo instante, às oscilações do mercado de trabalho. Mas é papel da escola desenvolver uma educação que não dissocie escola e sociedade, conhecimento e trabalho e que coloque o aluno ante desafios que lhe permitam desenvolver atitudes de responsabilidade, compromisso, crítica, satisfação e reconhecimento de seus direitos e deveres. Nesse aspecto, a Matemática pode dar sua contribuição à formação do cidadão ao desenvolver metodologias que enfatizem a construção de estratégias, a comprovação e justificativa de resultados, a criatividade, a iniciativa pessoal, o trabalho coletivo e a autonomia advinda da confiança na própria capacidade para enfrentar desafios.

Além de endossar as ideias contidas nos PCN, nossa posição pessoal é que, ao prover um contexto favorável à elaboração de provas significativas, respeitando a racionalidade dos alunos, a matemática escolar concorreria não só para formar um cidadão mais crítico e capaz de participar ativamente da vida social, mas também ofereceria aos alunos um interessante recurso pessoal para fruir a experiência intelectual.

Finalmente, para enfrentar o problema exposto, estabelecemos novas questões para a pesquisa:

- Como as demonstrações se relacionam com a constituição da ciência Matemática? A atividade matemática pode prescindir de processos de prova?

- Que papéis a prova matemática pode desempenhar na matemática escolar?

- O que distingue a prova matemática cabível na educação básica daquela praticada no ambiente acadêmico?

- Como se explica o aparente abandono do trabalho com argumentação e prova na matemática escolar brasileira das últimas décadas?

- O que poderia dificultar que os professores de matemática da educação básica implementem um trabalho significativo com argumentação e prova na sala de aula? 
A investigação sobre essas questões nos levou a organizar esta dissertação em duas partes. Na Parte 1, de natureza teórica, exploramos diversas referências bibliográficas da Educação Matemática, entre as quais, Balacheff, Sowder e Harel, De Villiers, Arsac, Machado, Pietropaolo, Fiorentini e Garnica. Além dessas, foram de extrema importância as obras de História da Matemática tais como Roque, Boyer e Aaboe.

$\mathrm{Na}$ investigação de natureza teórica, procuramos tecer relações intertextuais e nos organizamos a partir do seguinte programa:

- Discutir a nomenclatura relativa ao tema de pesquisa.

- Estudar possíveis tipologias de prova, para alargar as possibilidades de trabalho em sala de aula.

- Estudar as funções da prova em matemática, para compreender sua fecundidade na realidade escolar.

- Investigar o papel da demonstração na constituição da Matemática como ciência.

- Discutir papel da prova na matemática escolar tanto por sua potencialidade como pela realidade atual.

- Analisar algumas tendências em ensino de matemática que podem favorecer ou dificultar o trabalho com argumentação e prova em sala de aula.

- Examinar brevemente aspectos curriculares e da formação inicial de professores que podem estar dificultando o desenvolvimento do trabalho com a prova matemática na educação básica.

Consideramos que a investigação teórica ilumina a maior parte das questões que nos propusemos a investigar, com exceção talvez de duas ("Como os professores de matemática entendem a relação entre matemática e raciocínio lógico? Essa relação envolve, em alguma medida, as noções de argumentação e prova?" e "O que poderia dificultar que os professores de matemática da educação básica implementem um trabalho significativo com argumentação e prova em sua prática de sala de aula?"). Entendemos que, de fato, essas questões exigem a interlocução com professores de matemática da educação básica. Assim, a Parte 2 desta dissertação, que consiste na descrição e na análise das evidências derivadas de uma pesquisa de campo, procura não apenas dar concretude à investigação teórica, mas trazer à discussão aspectos até então não explorados em nosso quadro de investigação teórico.

A pesquisa de campo foi qualitativa, com a metodologia do estudo de caso. Com isso, vê-se que não pretendemos corroborar conjecturas eventualmente tecidas no resto do trabalho, 
mas, sobretudo, de retratar a forma como os sujeitos de pesquisa veem o tema, procurando analisar, inclusive, as contradições e dificuldades que emergiram no processo, à luz de nossa investigação teórica.

Embora, na organização do trabalho, a investigação teórica preceda a investigação de campo, isso não corresponde à sequência temporal das etapas da pesquisa. De fato, em boa parte do tempo, ambas as investigações ocorreram paralelamente, mas a investigação de campo acabou precedendo a fase de maior aprofundamento teórico e mesmo de maior apropriação de referenciais metodológicos para sua condução. Essa é uma informação importante, porque explica, em certa medida, algumas limitações e dificuldades enfrentadas em nossa pesquisa de campo.

Ainda que cientes das limitações deste trabalho, esperamos que ele seja útil a professores e pesquisadores que se interessam pelo tema, fornecendo, em língua portuguesa, um panorama e algumas chaves de leitura profícuas a respeito da prova em matemática, sobretudo no contexto da educação básica e da formação de professores.

Acreditamos que o Capítulo 1 pode ser particularmente útil a professores da educação básica, pois discutimos possíveis tipos de prova e também suas diferentes funções. Avaliamos que esses dois tópicos podem ampliar a concepção de prova do professor de forma fecunda para o trabalho pedagógico.

O Capítulo 2 aprofunda-se na investigação da forma como a noção de demonstração moldou a Matemática como uma ciência eminentemente dedutiva, tal como a reconhecemos hoje. Além disso, examinamos alguns episódios particulares da História da Matemática, procurando compreender como comparece o problema da validação do conhecimento.

Aos colegas que trabalham na formação inicial ou continuada de professores, acreditamos que o Capítulo 3 pode ser interessante, pois discute a prova em algumas tendências no ensino de matemática, na formação inicial de professores e em algumas diretrizes curriculares que pautaram a educação básica nas últimas décadas.

O Capítulo 4 apresenta nossa investigação de campo, descrevendo detalhadamente o ambiente, os sujeitos e a metodologia de pesquisa adotada. A análise e a interpretação das evidências são apresentadas no Capítulo 5.

Por fim, na Conclusão, respondemos às questões que nos colocamos nesta Introdução. 
Certamente, o esforço empreendido foi de grande valia para nossa formação pessoal, acadêmica e profissional. Em particular, nos enriqueceu como formadora de professores no Centro de Aperfeiçoamento do Ensino de Matemática (CAEM), do IME-USP, em que já temos ministrado versões preliminares de um curso de atualização para professores sobre o tema da argumentação e da prova em matemática - e que agora pode ser aprimorado. 
Parte 1

INVESTIGAÇÃO TEÓRICA 


\section{Explicar, provar, demonstrar: argumentar em matemática}

Segundo Balacheff $(2004,2008)$, a epistemologia da prova de cada pesquisador, ou seja, seu conhecimento, familiaridade e visão a respeito da verdade e da validade, molda seu quadro de investigação antes mesmo da escolha de um mote de pesquisa. $\mathrm{O}$ autor ressalta a importância de eliminar as confusões no campo de pesquisa sobre argumentação e prova em matemática, que se verificam em diferenças profundas e não explicitadas nas formas de entender o que é uma prova num contexto de ensino-aprendizagem. Sem esse esforço de convergência e explicitação de divergências, será quase impossível compartilhar resultados e, portanto, fazer qualquer progresso real nesse campo de pesquisa.

Concordando com a necessidade de tal esforço, este capítulo esclarece nossa visão da prova em matemática, delimitando o sentido que damos aos termos explicação, prova, demonstração e argumentação. Partimos da explicitação da nomenclatura adotada, mas não nos restringimos a ela, contextualizando essa compreensão à luz das referências teóricas consultadas, quase todas do campo da Educação Matemática.

\subsection{Nomenclatura}

Neste trabalho, tomamos os termos explicação, prova e demonstração seguindo a nomenclatura proposta por Balacheff (1987, p. 147-148):

- Explicação é um discurso que visa tornar compreensível a veracidade de uma proposição em que crê o sujeito que explica.

- Prova é uma explicação aceita por determinada comunidade em determinada época. Sua aceitação pode suscitar um debate sobre um sistema comum de validação entre os interlocutores.

- Demonstração é uma prova que obedece a uma forma particular, podendo ser aceita numa comunidade matemática. Ela deve ser uma sequência de enunciados organizados de acordo com determinadas regras: um enunciado é aceito como verdadeiro se pode ser deduzido de outro que o precede, com a ajuda de regras de dedução bem definidas. 
Observamos que esses significados não são partilhados por todos os trabalhos em Educação Matemática. Muitos deles, em língua inglesa, usam a palavra proof indistintamente para designar prova ou demonstração, o que pode levar a ambiguidades.

De acordo com Reid e Knipping (2010, p. 29), de fato, o sentido com que os educadores matemáticos usam a palavra proof nem sempre permite identificar claramente suas perspectivas sobre o conceito. Os mesmos autores esclarecem que, antigamente, em textos de Educação Matemática em língua inglesa sobre prova, era comum que demonstration designasse provas matemáticas. Agora, porém, essa palavra ocorre raramente nesse sentido, referindo-se mais frequentemente a um protesto político ou a uma apresentação destinada a mostrar como as coisas funcionam. Nas línguas românicas (o que inclui o português, o italiano, o espanhol e o francês), no entanto, as palavras cognatas demonstração, dimostrazione, demostración e démonstration seguem tendo o sentido proposto por Balacheff ou, em determinados contextos, são sinônimos de prova.

Particularmente em língua portuguesa, no campo acadêmico da Matemática, as palavras prova e demonstração frequentemente são tomadas como equivalentes; já termos como justificativa, explicação, argumento etc. costumam ser empregados de modo não sistemático para designar aquilo que aqui denominamos prova. No contexto da Educação Matemática, entretanto, alguns pesquisadores distinguem prova e demonstração ou então usam adjetivos para fazer as distinções desejadas:

Convém assinalar que em artigos sobre história da Matemática e, em particular, sobre Educação Matemática, são usados variados termos para se referir às demonstrações, tais como: demonstrações formais, demonstrações rigorosas, provas rigorosas ou simplesmente provas. E nem sempre essas expressões são utilizadas como sinônimas. É possível identificar, inclusive, significados não exatamente idênticos para uma determinada expressão em um mesmo artigo (PIETROPAOLO, 2005, p. 48).

O autor também esclarece que, em dicionários de filosofia, prova tem um significado mais amplo que demonstração: as provas seriam procedimentos para estabelecer um conhecimento válido, acomodando uma diversidade de meios, e as demonstrações matemáticas são consideradas tipos de prova, de modo que toda demonstração é uma prova, 
mas nem toda prova é uma demonstração (ABBAGNANO, $1982^{3}$ apud PIETROPAOLO, 2005, p. 48-49).

Nossa escolha deliberada pela nomenclatura proposta por Balacheff parece-nos em consonância com os dicionários de filosofia, mas não foi essa a razão que nos moveu. Adotamo-la por entender que ela enriquece a discussão dos processos de prova na matemática escolar focalizando o rigor. Essa escolha permite valorizar as provas que os alunos da educação básica podem elaborar no decorrer de seu desenvolvimento, num aperfeiçoamento constante de sua própria racionalidade, dialogando com, mas não se submetendo a parâmetros de rigor fixados pela Matemática. Com a nomenclatura proposta, esses parâmetros de rigor ganham fluidez e passam a ser considerados de acordo com o contexto social em que se elabora a prova.

Seja como for, neste estudo, entendemos provas e demonstrações como discursos argumentativos particulares da prática matemática, mas logo constatamos que era necessário justificar a inclusão da noção de demonstração no campo da argumentação, em função das diversas referências que antagonizam os dois termos.

D’Amore (2007, p. 348) esclarece que a retórica antiga distinguia argumentação e demonstração do seguinte modo:

- Argumentação é um discurso para convencer os outros.

- Demonstração é um discurso para convencer a si mesmo. Pode ser:

- demonstração para convencer (propriamente), em que a questão em jogo é "É verdade?";

- demonstração para entender, em que a questão em jogo é "Por que é verdade?"

Essa distinção ressalta o caráter social da argumentação e parece conceber a demonstração como uma reflexão de foro íntimo. Interpretando essa distinção de modo um pouco mais amplo, a argumentação estaria mais ligada à persuasão de um auditório, e a demonstração, à validação de uma afirmação. Entretanto, no contexto matemático (e científico, em geral), os objetivos da persuasão e da validação se confundem, uma vez que a falta da boa fé na busca da verdade descaracterizaria o conhecimento científico como tal. Um matemático faz demonstrações para convencer seus pares a respeito da verdade de uma afirmação exatamente porque elas permitem validá-la.

\footnotetext{
${ }^{3}$ ABBAGNANO, N. Dicionário de filosofia. Trad. A. Bosi. 2. ed. São Paulo: Mestre Jou, 1982.
} 
Segundo Plantin (2008, p. 91), a contraposição entre argumentação e demonstração, cujas origens são profundas, foi consideravelmente reforçada pelo Tratado da argumentação, de Chaim Perelman e Lucie Obrechts-Tyteca. Segundo Serra (1995), a nova retórica proposta por Perelman revaloriza a retórica antiga ao inseri-la numa teoria da argumentação mais abrangente, que visa estudar todo discurso cujo objetivo seja convencer ou persuadir, em qualquer campo. Explica ainda que, nessa teoria da argumentação, fica clara a distinção entre argumentar e demonstrar:

A argumentação assenta na equivocidade da linguagem natural; a demonstração assenta na univocidade da linguagem simbólica. A argumentação pode convencer ou não; a demonstração é um cálculo em que, dadas certas premissas, somos obrigados a aceitar uma certa conclusão (SERRA, 1995, p. 7).

Assim, concluímos que seria possível entender explicação e prova como argumentações com êxito local, capazes de convencer o próprio elaborador ou um grupo, mas apenas em determinado contexto; em outro, podem não convencer. Também nos parece que esse conceito de argumentação pode acomodar coerentemente as explicações e as provas, por consideramos que elas podem ser formuladas em língua natural ou mesmo por meio de linguagem visual ou esquemática.

Mas o que dizer da demonstração? Evocando a teoria da argumentação, Serra (1995) parece imputar à demonstração um poder de convencimento absoluto: é um cálculo que nos obriga a aceitar uma conclusão. Entretanto, a nomenclatura que adotamos a partir da proposta de Balacheff reserva-lhe um lugar mais modesto: considerando-a uma prova aceita por uma comunidade matemática, ele flexibiliza seu rigor, já que as comunidades matemáticas não são estáticas ou uniformes, e seus critérios variaram bastante ao longo da história.

De fato, Druck (2013) esclarece que as demonstrações atuais de um matemático geralmente são semiformais e envolvem um misto de língua natural e linguagem simbólica. $\mathrm{O}$ ápice do rigor numa demonstração seria alcançado por deduções sintáticas, presentes nas teorias axiomáticas estudadas pela Lógica Matemática, que são formuladas numa linguagem puramente simbólica e se baseiam em regras estritas de dedução. Para Bicudo $\left(2002^{4}\right.$ apud BATISTA; NAGAFUCHI, 2010, p. 1085):

\footnotetext{
${ }^{4}$ BICUDO, I. Demonstração em Matemática. Bolema, Rio Claro, v. 15, n. 18, p. 79-90, 2002.
} 
[...] as definições da Lógica deveriam modelar as demonstrações matemáticas, porém a demonstração que se encontra nos livros e periódicos é aquela que satisfaz a comunidade de especialistas, não interessando o quão distante ela possa estar do ideal lógico.

Assim, parece-nos que a demonstração como um cálculo dedutivo absoluto, que obriga a aceitar determinada conclusão, é um ideal raramente alcançado mesmo na atividade matemática acadêmica atual. Apesar disso, há que considerar o fato de que é tomada como um ideal no campo das chamadas "artes da prova". Segundo Plantin (2008, p. 103), uma demonstração "é uma sequência de proposições, na qual cada uma delas é ou um axioma, uma premissa tomada como verdadeira, ou deduzida dessas proposições por uma regra de inferência”, expressa numa linguagem impessoal, sem sinônimos ou termos de significação múltipla, sem traços de enunciação e interlocução do discurso e com referência exclusiva a objetos. Todas essas características conferem às demonstrações o desejado nível de rigor e confiabilidade.

Ao discutir se existe antagonismo ou continuidade entre argumentação e demonstração, Plantin (2008, p. 106-107) propõe que se diferencie "a demonstração como produto, ou seja, a demonstração monológica, impecavelmente exposta nos manuais, da demonstração como processo, tal qual empiricamente construída nas situações que podem dar lugar ao diálogo". No que tange aos objetivos da matemática escolar, essa distinção parece interessante, pois leva a considerar que, com a mediação do professor, os processos argumentativos em matemática podem evoluir gradativamente das provas informais para as demonstrações, por uma série de pequenas rupturas relativas à linguagem, à delimitação dos objetos, à explicitação das regras de inferência etc.

Entretanto, no campo da Educação Matemática, há um intenso debate acerca da continuidade ou ruptura entre argumentação e demonstração:

Existem essencialmente duas posições contrárias. Para alguns educadores, a separação entre as características funcionais e as características estruturais na análise da argumentação e da demonstração poderia acontecer também no nível cognitivo, ou seja, haveria uma ruptura cognitiva entre argumentação e prova [no sentido de demonstração]. Duval (1991), partidário dessa posição, sustenta que a argumentação não poderia sugerir um caminho para a construção da demonstração, pois a "heterogeneidade entre argumentação e demonstração ocorre não apenas do ponto de vista lógico, mas também do cognitivo". [...] No entanto, Boero, Garutti e Mariotti (1996) contestam fortemente a posição de Duval e defendem que haveria uma unidade cognitiva entre essas estruturas tomando como base os aspectos conceituais de Vergnaud (1990), as mudanças de quadros de Douady (1986), as 
expressões verbais e as heurísticas da argumentação e da demonstração. Segundo Boero (1999), a relação entre argumentação e prova, apesar de complexa, é produtiva e inevitável, tanto em Matemática como em Educação Matemática (PIETROPAOLO, 2005, p. 74).

Talvez, em parte, essa polêmica sobre ruptura ou continuidade cognitiva entre argumentação e demonstração no campo da Educação Matemática se assente em diferentes compreensões acerca da argumentação. Balacheff (1999) oferece três perspectivas teóricas sobre argumentação, para analisar sua relação com a demonstração: as de Chaim Perelman, Stephen Toulmin e Oswald Ducrot. Muito brevemente, ele esclarece que, para Perelman, o foco da argumentação é persuadir o auditório (o leitor, o ouvinte etc). Nessa perspectiva, a validade do argumento seria relativizada em função do auditório; sua validade equivale praticamente a sua aceitação. Já na perspectiva de Toulmin, a validade de uma afirmação está relacionada à estrutura do discurso e à suposta veracidade das premissas aceitas por determinada comunidade a partir de certos critérios. Por fim, Ducrot situa a força de um argumento no encadeamento do discurso que, sobretudo por meio das conjunções, assinala uma intenção argumentativa global.

Para Balacheff, na perspectiva de Perelman, é mais coerente considerar uma ruptura entre argumentação e demonstração. Entretanto, na de Toulmin, parece-lhe coerente que se admita um continuum entre argumentação e demonstração, embora ele deixe claro que não sabe como o próprio Toulmin se posiciona nessa questão.

D’Amore (2007) dedica toda uma seção de seu livro à distinção entre argumentação e demonstração, trazendo as contribuições de Raymond Duval, que apoia a ideia da ruptura, embora destaque que, "como o raciocínio dedutivo se expressa, se faz, se desenvolve, se explica no interior do próprio discurso natural, aos alunos essa diferença [...] termina escondida e não é revelada" (D’AMORE, 2007, p. 359).

Ainda que provisoriamente, posicionamo-nos pela continuidade entre argumentação e demonstração, por todo o exposto, inclusive o último excerto: o raciocínio dedutivo (tomado aí como o processo cognitivo básico sob a demonstração) se expressa e se desenvolve no interior do discurso natural.

Assim, em vez de nos deter no que diferencia argumentação e demonstração, concentramo-nos no que as une: um encadeamento de proposições para convencer a si ou a outros da verdade ou das razões da verdade. Em vez de contrapor a equivocidade da 
linguagem natural à univocidade da linguagem simbólica, focalizaremos os parâmetros de rigor em função do consenso estabelecido por diferentes comunidades. Em vez de contrapor discurso e cálculo, incluiremos o cálculo no discurso matemático. Nesses termos, prova e demonstração são consideradas aqui diferentes instâncias da argumentação em matemática, cujo refinamento varia conforme o tipo de interação social em que se inserem (Figura 1). Uma explicação situa-se no nível do sujeito, permitindo-lhe limitar-se aos próprios saberes e competências. Já a prova em matemática é vista como uma forma de argumentação compartilhada socialmente; devendo ser aceita por uma comunidade (uma turma escolar e seu professor, por exemplo), exige que o sujeito se aproprie minimamente de competências e saberes alheios, por meio de reformulações a partir de questionamentos ou contraexemplos, ou ainda pela antecipação de possíveis refutações. Por fim, uma demonstração matemática será uma forma específica de prova que deve ser mais rigorosa para ser aceita por uma comunidade matemática.

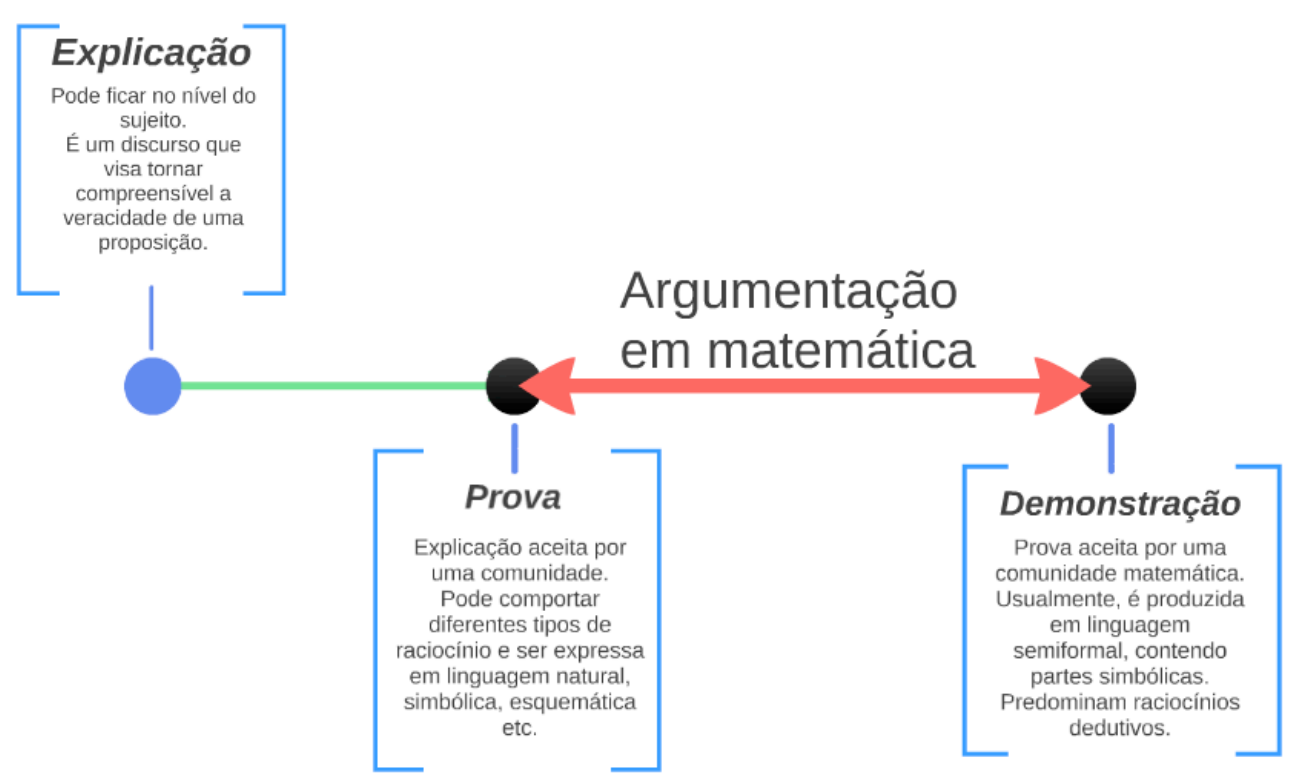

Figura 1

Por fim, em função da compreensão aqui exposta, cumpre dizer que, ao citar indiretamente outros autores, dizemos prova ou demonstração de acordo com o sentido que depreendemos do texto original, o que nem sempre coincide com a expressão usada pelo autor ou com sua tradução literal. 


\subsection{Tipos de prova na matemática escolar}

Embora exista uma clara gradação no trabalho cognitivo de explicar, provar e demonstrar, não vamos considerar que ela obedeça apenas e necessariamente a um aumento da capacidade cognitiva do sujeito, mas também a um aumento de "engajamento cognitivo". Ao considerar prova e demonstração diferentes instâncias da argumentação em matemática, reforçamos o papel da interação social e da comunicação em sua elaboração. Mesmo um matemático profissional, dependendo do contexto, pode elaborar uma prova em vez de uma demonstração. Um aluno da educação básica, num contexto específico e com estímulos apropriados, pode elaborar uma demonstração relativa a um tema matemático que lhe seja familiar ou significativo.

Balacheff (1987) assinala que o engajamento do sujeito em uma ou outra depende das exigências da situação e da análise de risco envolvida. Para ilustrá-lo, usa uma pertinente metáfora de Popper, que parafraseamos assim: se eu compro um livro e recebo como troco vinte centavos em moedas, provavelmente não vou questionar sua veracidade. Se alguém me perguntar se tenho certeza de que as moedas são verdadeiras, dou-lhes uma rápida olhada e, não encontrando nada que chame a atenção, responderei "sim". Porém, se algo realmente importante como a vida de um homem depender da veracidade dessas moedas, pedirei ao presidente do Banco Central que as certifique. Ou seja, respondendo a uma certa economia de esforço, o sujeito não vai mobilizar senão aquilo que é realmente necessário na situação em tela.

Com isso, Balacheff distingue situações que demandam provas daquelas que as dispensam. As situações em que os alunos apenas operam algoritmos, seguem comandos estritos ou fazem atividades rotineiras permitem economizar o exame das condições de validade da ação. Por outro lado, há situações que exigem decisões, previsões, defesa ou refutação de afirmações - estas demandam provas. Entre essas situações, Balacheff distingue dois tipos: as de decisão e as de validação. No primeiro caso, a situação não demanda provas explícitas, mas a decisão exige que esse processo seja simulado internamente. Pode-se pensar que, nesse caso, a prova não é o objetivo final da ação, mas a ferramenta que permite decidir.

É interessante notar que a ênfase de Balacheff na situação como motor da elaboração de provas responde, em alguma medida, à observação de De Villiers (2001) de que a principal dificuldade para se ensinar prova em matemática é que os alunos costumam não ver sua 
necessidade. Ora, se nas aulas de matemática os alunos apenas operarem algoritmos ou procedimentos rotineiros que já estão validados de partida - pela autoridade do professor ou do livro didático, por exemplo -, a prova é realmente desnecessária. E se, nessas condições, o professor elaborar e apresentar provas à classe, será tedioso acompanhá-lo - especialmente se essas provas forem demasiado rigorosas -, pois os alunos não estarão engajados numa real situação de validação. Por essa razão, Balacheff (1999) fala na necessidade de devolver aos alunos a responsabilidade por sua produção matemática por meio de situações planejadas com esse fim.

Combinado com diferentes graus de desenvolvimento de uma racionalidade matemática e de uma linguagem apropriada, esse engajamento cognitivo despertado pela situação pode dar origem a diferentes tipos de prova matemática, que vêm sendo descritas de modos diversos por diferentes pesquisadores.

Sowder e Harel (1998), por exemplo, propõem três grandes tipos de esquema de prova em que, em princípio, se podem enquadrar as provas de alunos da educação básica: externos, empíricos e analíticos. Cada uma dessas categorias apresenta subtipos (Quadro 2).

Quadro 2 - Tipos de prova (Sowder e Harel)

\begin{tabular}{clc}
\hline esquemas de prova & \multicolumn{1}{c}{ características } & subtipos \\
\hline & Tanto o que convence o estudante quanto o que ele & \\
& usa para convencer os outros se origina de uma fonte & autoritários \\
externa: a autoridade do professor ou de um colega & rituais \\
externos & tido como mais capaz, o livro didático, a forma do & simbólicos \\
& texto em que a prova é exposta ou uma interpretação & \\
& equivocada do uso dos símbolos matemáticos. & \\
\hline empíricos & O estudante se convence e busca convencer os & perceptivos \\
& demais por meio de um desenho ou a partir da & baseados em \\
& observação de vários exemplos, que apresentam, exemplos (indutivos) \\
& eventualmente, "padrões parciais". & \\
\hline & O estudante percebe e usa a estrutura subjacente a um & \\
& padrão para convencer aos demais e a si mesmo. Esse & \\
& tipo de esquema tem três características: & \\
& generalidade, pensamento operacional e inferência & transformacionais \\
& lógica. No subtipo axiomático, o estudante enxerga a & axiomáticos \\
organização do conhecimento matemático por meio & \\
& das conexões lógicas entre definições, axiomas e & \\
teoremas. &
\end{tabular}


Além de estabelecer uma tipologia de provas bastante útil para a leitura da realidade escolar, Sowder e Harel (1998) propõem estratégias que um professor poderia usar para que os alunos avancem em direção a um refinamento argumentativo. Por exemplo, um estudante que confia demais na autoridade do professor poderia se beneficiar ao trabalhar em pequenos grupos, em atividades que demandem conjecturas e provas. Estudantes que ingenuamente dão exemplos como esquemas de prova podem se beneficiar de atividades que envolvam exemplos traiçoeiros. (Por exemplo: será verdade que, para qualquer número natural $n$, a expressão $n^{2}+n+41$ resulta num número primo? Isso é verdade para $n=0,1,2,3,4,5,6 \ldots$, 39 , mas é falso para $n=40$. Para alguns alunos, os testes com os valores de 0 a 39 podem ser muito traiçoeiros e, por isso, a situação é excelente para fazê-los redimensionar sua confiança nas provas baseadas em exemplos.)

Balacheff $(1987,1988)$ também propõe uma tipologia de provas que consideramos valiosa, especialmente pela profundidade de sua análise de cada tipo e da passagem de um a outro tipo. Tal proposta não vai de encontro à de Harel e Sowder, mas entendemos que elas se complementam.

Balacheff distingue provas pragmáticas e provas intelectuais. A adoção de um ou outro tipo de prova depende das possibilidades da situação. Considerando o contexto didático, o autor afirma que, se a situação permite acesso direto à experiência, a tendência é que os alunos não passem às provas intelectuais (ao menos na educação básica), uma vez que isso exigirá o árduo esforço de desenvolvimento de linguagens capazes de expressar as ideias por trás da ação. Por outro lado, a passagem às provas intelectuais é desejável, já que as pragmáticas estão comprometidas com as singularidades dos eventos que as constituem e, portanto, têm alcance limitado.

Assim, na passagem das provas pragmáticas às intelectuais, intervêm não apenas as características da situação, mas também o desenvolvimento de linguagens apropriadas, tanto no âmbito da língua materna quanto no da própria matemática, que comporta linguagens próprias. Enquanto a comunicação das provas pragmáticas se dá pela exibição da ação que funciona, as provas intelectuais exigem uma linguagem funcional, capaz de captar e expressar o caráter genérico dos objetos e relações focalizados. 
Essa passagem delicada não se dá de uma só vez, mas é um processo. Num primeiro momento, os alunos podem evocar a ação no discurso e sentir dificuldade para se descolar da prática. A transformação de linguagem necessária exigirá, segundo o autor:

- descontextualização: abandonar o objeto real, o lugar efetivo das ações, para chegar a uma classe de objetos independentes das circunstâncias anexas ou anedóticas de sua ocorrência,

- despersonalização: tornar a ação independente daquele que a praticou, e

- destemporalização: liberar as operações de sua data e duração.

Entendemos que essa passagem não ocorre necessariamente em determinada idade ou ano escolar, como se fossem níveis dentro de um modelo de desenvolvimento. Tampouco fica garantida a adesão às provas intelectuais, uma vez que ela se faça numa situação específica. Pelo contrário, essa passagem depende do sistema de saberes mobilizados na situação, do grau de desenvolvimento de uma linguagem funcional referente aos objetos e relações em questão, de certa racionalidade que leva a uma postura mais teórica ou mais prática, da possibilidade de acesso direto à experiência etc. As provas pragmáticas podem mesmo constituir o estágio inicial da gênese de um novo saber, ainda que o sujeito seja estudante experiente ou matemático profissional, desde que o problema em questão envolva novos objetos e relações.

Assim, o autor observa que a passagem das provas pragmáticas às intelectuais envolve o desenvolvimento não só de uma linguagem, mas também do próprio saber, que tem de evoluir de conhecimentos práticos para conhecimentos teóricos que possam ser tomados como objeto de reflexão (Quadro 3).

Quadro 3 - Das provas pragmáticas às demonstrações

\begin{tabular}{|c|c|c|}
\hline natureza das concepções & formulação & validação \\
\hline práticas (saber-fazer) & exibição & \\
\hline saber como objeto & $\begin{array}{l}\text { linguagem da familiaridade } \\
\text { (narrativa/descritiva) }\end{array}$ & $\begin{array}{l}\text { provas pragmáticas } \\
\text { (teorema-em-ação) }\end{array}$ \\
\hline $\begin{array}{l}\text { (connecimento) } \\
\text { saber teórico e reconhecido } \\
\text { (conhecimento científico) }\end{array}$ & $\begin{array}{l}\text { linguagem funcional } \\
\text { formalismo ingênuo }\end{array}$ & $\begin{array}{c}\text { provas intelectuais } \\
\text { demonstrações (teoremas) }\end{array}$ \\
\hline
\end{tabular}


No contínuo que vai das provas pragmáticas às intelectuais, Balacheff categoriza alguns tipos de prova: o empirismo ingênuo, o experimento crucial, o exemplo genérico e o experimento mental. O que marca essa gradação são a percepção e o tratamento da questão da generalização.

No empirismo ingênuo, o sujeito não percebe claramente o problema da generalização e obtém certeza da validade de uma proposição a partir da observação de um pequeno número de casos. Já no experimento crucial ele percebe o problema da generalização, que tenta contornar fazendo um experimento tão livre quanto possível de particularidades perceptíveis. Ainda é um procedimento de prova fundamentalmente empírico.

No exemplo genérico, explicitam-se as razões da validade de uma proposição. O objeto que se opera ou transforma ainda é particular, mas já é visto como um representante característico de uma classe de objetos. A prova emerge não das propriedades particulares do objeto, mas das propriedades características dessa classe de objetos; no entanto, o sujeito ainda não consegue se descolar completamente da exibição de um dos seus representantes e, por isso, trata-se ainda de um processo parcialmente empírico.

Entre o exemplo genérico e o experimento mental é que se encontra a passagem das provas pragmáticas às intelectuais. No experimento mental, o sujeito invoca a ação já interiorizada e se torna capaz de formular as razões da validade de uma proposição sem a necessidade de exibir um representante particular da classe de objetos à qual se aplica. No entanto, Balacheff diz que, ainda assim, nesse tipo de prova, existe certa marca da temporalidade e do contexto. Então, um experimento mental ainda não é uma demonstração, e Balacheff apenas menciona que se poderiam descrever outros tipos de prova entre eles, que se distinguiriam pelos níveis de descontextualização, despersonificação e destemporalização, conforme já exposto.

Para ilustrar os tipos de prova descritos, Balacheff usa exemplos retirados do contexto escolar, especificamente sobre o número de diagonais de um polígono convexo. No Quadro 4, transcrevemos livremente esses exemplos. 
Quadro 4 - Tipos de prova (Balacheff)

\begin{tabular}{|c|c|}
\hline tipo de prova & exemplo \\
\hline $\begin{array}{l}\text { empirismo } \\
\text { ingênuo }\end{array}$ & $\begin{array}{l}\text { Lionel e Laurent contam cinco diagonais num pentágono. Releem o enunciado, } \\
\text { que pedia para determinar o número de diagonais, fazem uma nova } \\
\text { representação do pentágono, contam novamente e concluem: "está provado, } \\
\text { tem cinco vértices e cinco diagonais". } \\
\text { Em seguida, quando questionados, afirmam que o hexágono terá seis diagonais. } \\
\text { O exemplo do pentágono bastou para que tenham como certa a conjectura sobre } \\
\text { a igualdade entre o número de vértices e de diagonais. }\end{array}$ \\
\hline $\begin{array}{l}\text { experimento } \\
\text { crucial }\end{array}$ & $\begin{array}{l}\text { Após elaborar sua conjectura, Laura diz que agora é preciso testá-la "para uma } \\
\text { figura imensa". Nadine sugere que seja testada para um polígono de } 15 \text { lados e } \\
\text { diz que, se funcionar, deve funcionar para todos os outros também. }\end{array}$ \\
\hline $\begin{array}{l}\text { exemplo } \\
\text { genérico }\end{array}$ & $\begin{array}{l}\text { Lionel e Laurent agora aperfeiçoam sua conjectura e sua prova. Escrevem que } \\
\text { "Num polígono de seis vértices, de cada um saem três diagonais, totalizando } \\
\text { 18. Mas, como cada diagonal junta dois pontos, temos só } 9 \text { diagonais: } 18: 2= \\
\text { 9. O mesmo vale para } 7 \text { vértices, } 8,9,10,11 \ldots \text { etc." }\end{array}$ \\
\hline $\begin{array}{l}\text { experimento } \\
\text { mental }\end{array}$ & $\begin{array}{l}\text { Cristophe e Bertrand elaboram a seguinte prova: "Conhecendo o número de } \\
\text { vértices do polígono, de cada ponto partirão (número de vértices) - (dois } \\
\text { vizinhos + ele mesmo) [diagonais]. Então, é preciso multiplicar o que foi } \\
\text { encontrado pelo número de vértices, pois de cada um parte o mesmo número de } \\
\text { diagonais. Mas contamos duas vezes cada diagonal. O número encontrado tem } \\
\text { de ser dividido por dois, para contar uma vez só cada diagonal." }\end{array}$ \\
\hline
\end{tabular}

Comparando as tipologias propostas por Sowder e Harel e por Balacheff, notamos que os primeiros dão esquemas de prova mais amplos, incluindo, por exemplo, argumentos de autoridade. Isso nos parece importante, já que, de fato, observamos seu uso entre os alunos na prática escolar, e esse é um desafio que precisa ser enfrentado. Por outro lado, Balacheff discute mais pormenorizadamente as provas pragmáticas e intelectuais (que corresponderiam, na tipologia de Sowder e Harel, aos esquemas de prova empíricos e analíticos, em parte). O Quadro 5 mostra como entendemos uma possível correlação entre as duas referências.

Quadro 5 - Comparação entre a tipologia de provas de Balacheff e a de Sowder e Harel

\begin{tabular}{|c|c|}
\hline Sowder e Harel & Balacheff \\
\hline $\begin{array}{l}\text { esquemas de prova externos } \\
\text { (autoritários, rituais, simbólicos) }\end{array}$ & - \\
\hline $\begin{array}{c}\text { esquemas de prova empíricos } \\
\text { (perceptual ou por meio de exemplos) }\end{array}$ & $\begin{array}{c}\text { provas pragmáticas } \\
\text { (empirismo ingênuo, experimento crucial e exemplo genérico) }\end{array}$ \\
\hline $\begin{array}{c}\text { analíticos } \\
\text { (transformacionais ou axiomáticos) }\end{array}$ & $\begin{array}{l}\text { provas intelectuais } \\
\text { (experimento mental) } \\
\text { demonstrações }\end{array}$ \\
\hline
\end{tabular}


Ambas as propostas salientam que é excessivo esperar que alunos da educação básica elaborem demonstrações, especialmente se não houver um trabalho contínuo e de longo prazo nesse sentido. Exatamente por isso, é importante ter em conta essas tipologias de prova. Segundo Hanna $\left(1990^{5}\right.$ apud AGUILAR JÚNIOR; NASSER, 2012, p. 135), “as provas passam a ter diferentes graus de validade formal, mantendo o mesmo grau de aceitação, permitindo com isso a reconsideração do que poderia ser prova ideal e do que se deveria ensinar nas escolas".

\subsection{Funções da prova em matemática}

Até o momento, entendemos que uma prova em matemática é um discurso que visa convencer, a si ou a outros, da verdade ou das razões da verdade de uma afirmação matemática, devendo ser aceita por uma comunidade. Nessa acepção, já estão explicitadas duas das possíveis funções de uma prova: convencimento e explicação.

A função de convencimento (ou verificação, ou validação) é, segundo De Villiers (2001), a mais frequentemente reconhecida por professores e pesquisadores em Educação Matemática. Segundo Nasser e Tinoco (2001, p. 3), essa função, que as autoras referem como função de validação:

[...] é, sem dúvida alguma, fundamental na Matemática, mas nem sempre é motivadora para os alunos da escola básica. Muitas vezes, o resultado é óbvio para eles, que não veem necessidade alguma de verificar sua veracidade. Essa função se torna altamente motivadora quando há alguma dúvida, ou seja, quando é preciso validar ou refutar uma conjectura.

Balacheff (1987) aborda o problema da prova principalmente a partir dessa função, destacando a importância da interação social no contexto da validação do conhecimento matemático. Com isso, é forçoso observar o caráter dialético das provas e refutações, que implicam o problema da contradição. Balacheff examina a contradição colocando-a em relação ao sujeito: não existe contradição sem um sistema cognitivo que a perceba. Assim, o que parece contraditório a uma pessoa, pode não parecê-lo a outra. O que determina a percepção da contradição são os conhecimentos mobilizados por determinada situação. Para

\footnotetext{
5 HANNA, G. Some Pedagogical Aspects of Proof. Interchange. The Ontario Institute for Studies in Education, Ontario, v. 21, n. 1, p. 6-13, 1990.
} 
que o sujeito seja capaz de perceber uma contradição, é preciso que uma situação mobilize uma expectativa, que terá de ser simultaneamente criada e frustrada.

Arriscamo-nos a formular um exemplo do caráter subjetivo da contradição, retirado de nossa própria experiência em sala de aula. São muito conhecidos certos problemas geométricos em que se produz uma contradição entre a expectativa da conservação da área $\mathrm{e}$ o cálculo divergente da área de figuras que diferem apenas por seu rearranjo. É o caso do problema proposto a duas turmas do $9^{\circ}$ ano do ensino fundamental de uma escola particular paulistana (Figura 2).

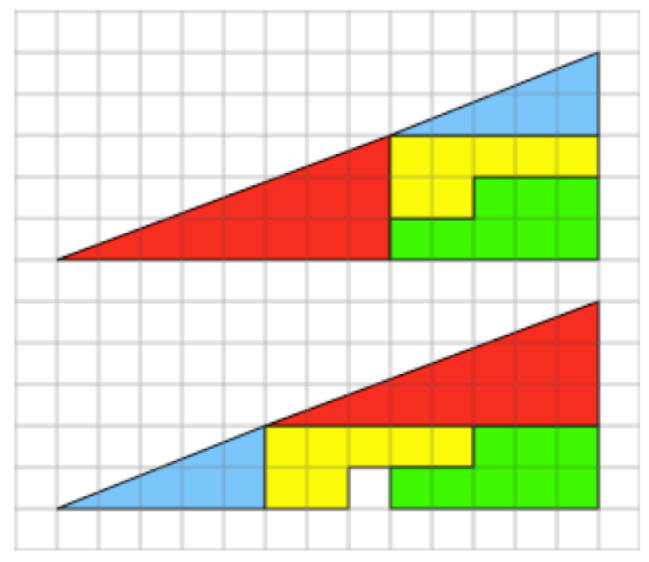

Figura 2

Aparentemente, o rearranjo das mesmas peças dentro de um mesmo triângulo produz uma unidade de área a mais na segunda figura. Resolver esse problema é justamente ultrapassar a contradição aparente. Ao propor esse problema, nossa expectativa era de que a superação da contradição mobilizasse o conhecimento acerca das razões trigonométricas, que vinham sendo estudadas por essas turmas. Mas aconteceu que uma parcela significativa dos alunos não reconheceu aí nenhuma contradição, mesmo instados a calcular a área das duas figuras. $\mathrm{Na}$ ocasião, foi possível investigar e concluir que esses alunos não tinham uma expectativa clara a respeito da conservação da área - o que alterou completamente os objetivos da atividade, como se pode imaginar.

Esse exemplo ilustra como, no contexto da validação, a necessidade da prova exige a mediação do professor, que deve identificar os saberes que poderiam sustentar uma dúvida racional que encerrasse a possibilidade de contradição. 
A outra função que fica clara em nossa ideia de prova é a de explicação, ou seja, é aquela que permite não só verificar que um resultado é verdadeiro, mas que permite compreender por que ele é verdadeiro.

De Villiers (2001, p. 32) afirma que, muitas vezes, na prática da investigação matemática, a convicção a respeito de determinado resultado é obtida por meios empíricos ou por intuições, que nada têm a ver com uma demonstração rigorosa. Por outro lado, segundo o autor, em alguns casos, só a demonstração pode elucidar a estrutura subjacente ao problema e, com isso, explicitar as razões da validade de um resultado.

Tomemos outro exemplo. Um website de desafios matemáticos para estudantes e leigos curiosos publicou o seguinte desafio (ASSIS JR.):

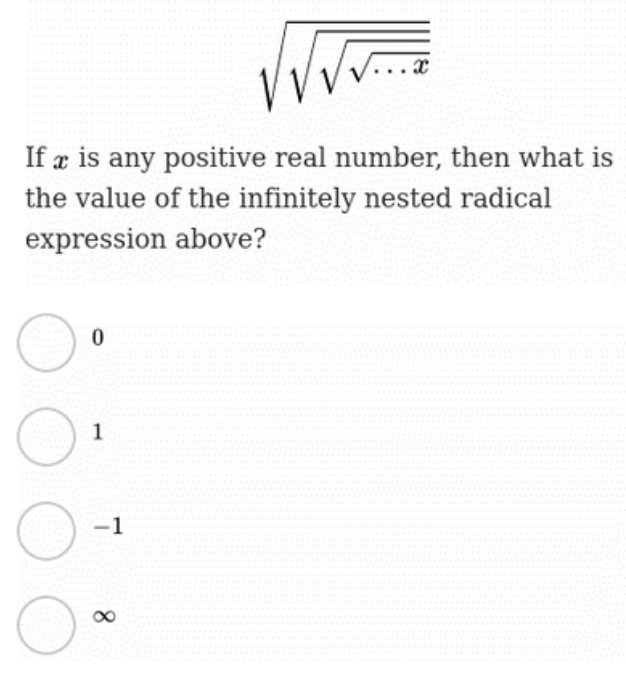

(Se x é um número real positivo, qual é o valor da expressão dada por infinitos radicais sucessivos?)

Uma possível abordagem empírica é verificar numa calculadora comum que, tomando um número racional positivo qualquer ${ }^{6}$ e apertando muitas vezes a tecla sqrt (ou $\left.\sqrt{ }\right)$, o resultado vai se aproximando de 1 . Isso pode ser simultaneamente um procedimento de descoberta e uma prova pragmática no contexto da educação básica, e caberá ao professor discutir com os alunos suas limitações. Por exemplo, ele pode chamar atenção para o fato de que o teste da calculadora só aceita valores racionais de $x$. De acordo com a avaliação do professor dos saberes demandados e disponíveis, talvez fosse possível tentar uma prova intelectual. No entanto, é inequívoco que essa abordagem empírica fornece algum grau de convicção de que a resposta do problema é 1, mas sem dar as razões desse resultado.

\footnotetext{
${ }^{6} \mathrm{Na}$ calculadora, é impossível tomar um número irracional.
} 
Poderíamos argumentar, de modo algo impreciso, que, partindo de um número maior que 1, o resultado da raiz quadrada deve diminuir sucessivamente. Porém, partindo de um número entre 0 e 1 , ele deve aumentar sucessivamente, de modo que o número 1 seria uma espécie de fronteira entre os dois casos $(\sqrt{1}=1)$. Se convencer a comunidade em questão, esse argumento pode constituir uma prova informal que explica um pouco melhor por que o resultado é 1. Em todo caso, é importante reconhecer que, em última instância, também essa argumentação tem uma base empírica e não chega a tocar claramente num conceito que não subjaz só à resposta, mas já à pergunta do problema, que é o conceito de limite.

Um esboço de demonstração poderia ser:

$$
\left.\sqrt{\sqrt{\sqrt{\sqrt{\sqrt{\sqrt{{ }_{1} x}}}}}}=\left(\left(\left(x^{\frac{1}{2}}\right)^{\frac{1}{2}}\right)^{\frac{1}{2}}\right)^{\frac{1}{2}}\right)^{\frac{1}{2}}=\lim _{n \rightarrow \infty} x^{\frac{1}{2^{n}}}=x^{0}=1
$$

Embora esse argumento não seja suficientemente detalhado para ser aceito como demonstração (não explicitamos as hipóteses e a tese, por exemplo), já é possível perceber que esse esboço envolve uma mudança de linguagem. O significado algo vago das reticências foi explicitado precisamente, permitindo uma abordagem teórica. Com isso, esclareceu-se a estrutura subjacente ao problema, e o efeito é que - desde que tenhamos familiaridade com a teoria envolvida - podemos compreender por que o resultado do problema é 1.

Com o exemplo anterior, não estamos sugerindo que seja sempre necessário chegar a uma demonstração para compreender as razões da veracidade de um resultado. Inclusive, o exemplo deixa claro que a passagem a uma demonstração exige o domínio de linguagens e saberes sem os quais ela não só perderia sua capacidade de explicação como seria ininteligível. O exemplo pretende apenas mostrar como a função de convencimento e a função explicativa podem ser atributos diferentes de diferentes tipos de prova.

$\mathrm{Na}$ realidade, dependendo da situação, pode ocorrer o contrário: uma prova informal pode explicitar melhor as razões da validade de um resultado do que uma demonstração. Por exemplo, se queremos provar que a soma de dois números naturais pares é sempre um 
número par. Um aluno do ensino fundamental talvez compreenda melhor as razões pelas quais isso é verdade por um exemplo genérico do que por uma demonstração algébrica, uma vez que pode ainda não ter aprendido efetivamente essa linguagem.

Quadro 6 - Soma de números pares (duas provas)

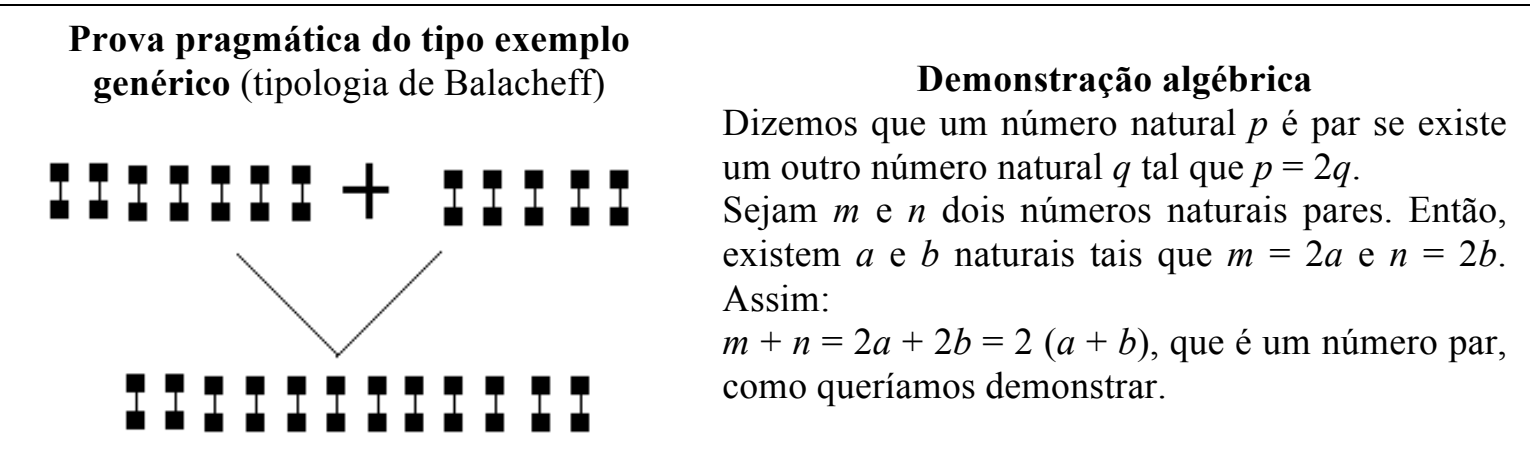

Outra função possível da prova em matemática é a de descoberta. Por exemplo, analisando e manipulando o exemplo genérico acima, formulado visualmente, pode-se descobrir que a soma de dois números naturais ímpares também resulta sempre num número par (Figura 3).

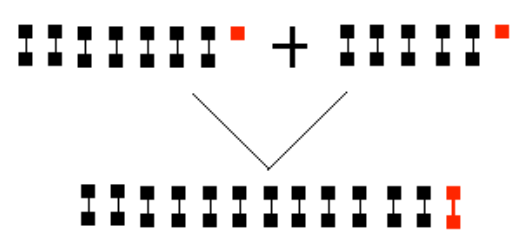

Figura 3

Referindo-se particularmente às demonstrações, De Villiers (2001, p. 33) afirma:

Diz-se frequentemente que os teoremas são a maior parte das vezes descobertos por meio da intuição e de métodos quase-empíricos, antes de ser verificados por meio de demonstrações. Contudo, existem numerosos exemplos, na história da matemática, de novos resultados que foram descobertos ou inventados por processos puramente dedutivos; de fato, é completamente improvável que alguns resultados (como, por exemplo, as geometrias não euclidianas) pudessem alguma vez ter sido encontrados por mera intuição e/ou pela utilização de métodos quase-empíricos. [...] Para o matemático profissional, a demonstração não é apenas um meio de verificação de um resultado já descoberto, mas também muitas vezes um processo de explorar, analisar, descobrir e inventar novos resultados. ${ }^{7}$

\footnotetext{
${ }^{7}$ Nota-se no excerto que, para De Villiers, uma demonstração (ou prova formal) se caracteriza por raciocínios puramente dedutivos - o que, em teoria, não coincide exatamente com a forma como vimos usando o termo demonstração. Porém, na prática, considerando os critérios de rigor vigentes entre os matemáticos profissionais, as duas noções se sobrepõem.
} 
No mesmo artigo, o autor dá um exemplo interessante de descoberta a partir da demonstração, que transcrevemos livremente aqui.

Vamos considerar que uma pipa seja um quadrilátero convexo que apresenta um par de lados consecutivos congruentes, onde $\mathrm{AB}=\mathrm{AD}$ e $\mathrm{BC}=\mathrm{CD}$. Então, tomando os pontos $\mathrm{M}$, $\mathrm{N}, \mathrm{P}$ e Q, pontos médios dos lados da pipa, podemos nos perguntar acerca da natureza do quadrilátero MNPQ (Figura 4).

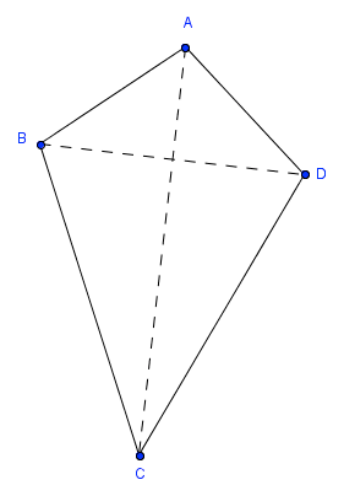

Figura 4

Fazendo a construção no software de geometria dinâmica Geogebra, verificamos empiricamente que MNPQ é um retângulo. Aliás, mesmo alterando uma das condições iniciais e tornando ABCD um quadrilátero côncavo, MNPQ ainda é um retângulo (Figura 5).
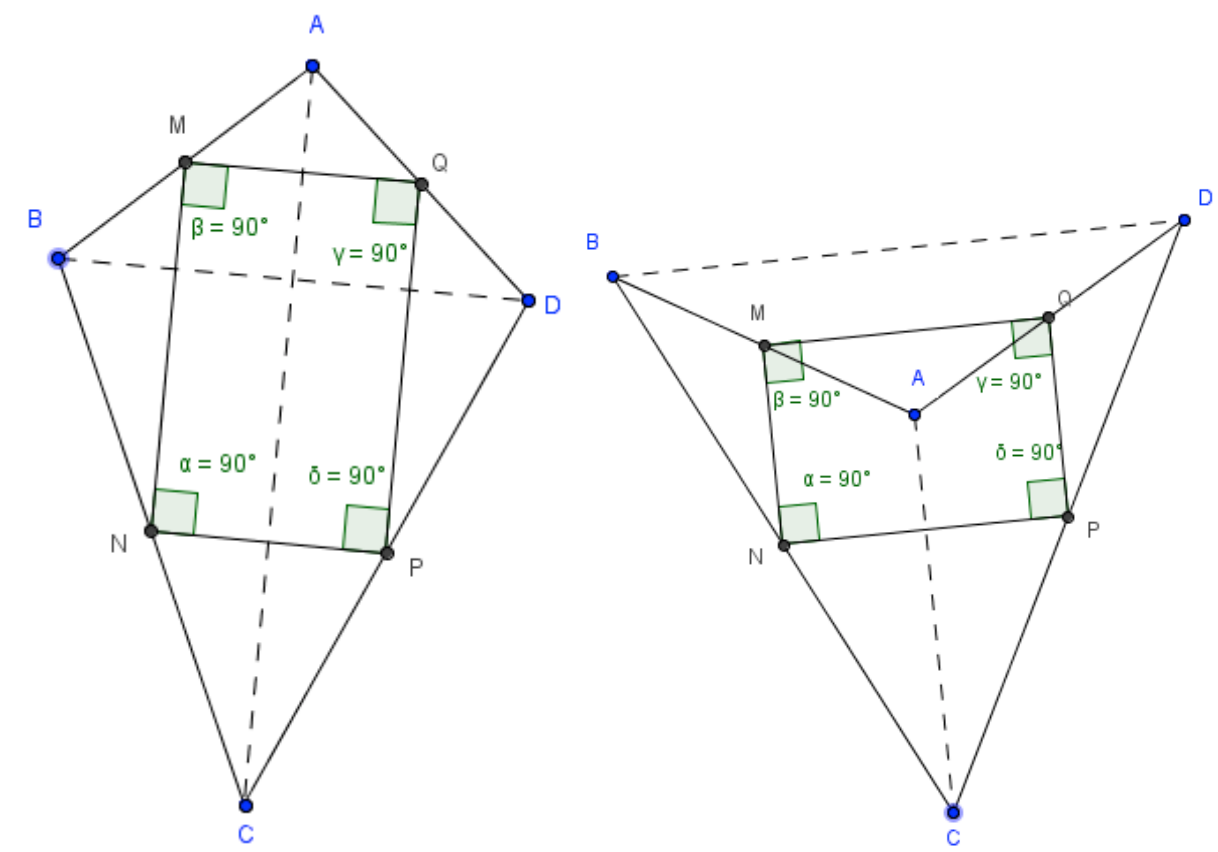

Figura 5 
A comprovação empírica, feita por meio da geometria dinâmica, não é suficiente para esclarecer por que MNPQ é um retângulo. Mas, ao elaborar uma demonstração, não só compreendemos a razão para isso, como acabamos por descobrir que as condições iniciais do problema poderiam ser mais frouxas: para que MNPQ seja um retângulo, é suficiente que o quadrilátero $\mathrm{ABCD}$ tenha diagonais perpendiculares.

Vejamos o argumento principal contido na demonstração do resultado inicial. Pela definição de quadrilátero do tipo pipa, é possível concluir que a reta $\mathrm{AC}$ é um eixo de simetria, de modo que os segmentos $\mathrm{AC}$ e BD são perpendiculares. Então, como M é o ponto médio do segmento $\mathrm{AB}$, podemos usar a recíproca do teorema de Tales para concluir que as retas $\mathrm{MQ}$ e $\mathrm{BD}$ são paralelas. Isso implica que $\angle \mathrm{AMQ}$ e $\angle \mathrm{ABD}$ são congruentes. Analogamente, concluímos que os ângulos $\angle \mathrm{BAC}$ e $\angle \mathrm{BMN}$ são congruentes. Então, como $\angle \mathrm{BMN}, \angle \mathrm{AMQ}$ e $\angle \mathrm{NMQ}$ formam um ângulo raso, temos que $\angle \mathrm{NMQ}$ é reto. Analogamente, podemos mostrar que os demais ângulos de MNPQ são retos.

Fica claro, portanto, que, no cerne da demonstração, está o fato de que as diagonais de uma pipa são perpendiculares, mas a congruência entre os pares de lados não é usada. Daí sai a descoberta de que o resultado é mais geral do que permitia supor o problema inicial.

A quarta função da prova é a comunicação de resultados matemáticos. Estendendo à provas o que De Villiers (2001) refere sobre a demonstração, podemos dizer que ela acaba por criar um fórum para o debate crítico, quer entre matemáticos profissionais (demonstrações), quer entre estudantes e professores ou mesmo apenas entre estudantes.

A comunicação pressupõe a organização das ideias, que, dada a natureza científica da matemática, acabam por adquirir uma forma argumentativa. Por isso mesmo, a comunicação de resultados matemáticos, oralmente ou por escrito, reveste-se de uma importância particular no contexto pedagógico, afinal, por meio dela, os alunos acabam exercitando a metacognição, tomando consciência do que sabem, de por que o sabem e de como os resultados se conectam.

A última das funções da prova que trazemos aqui a de sistematização. Porém, como destaca De Villiers (2001, p. 34), essa função não é comum a todo tipo de prova, mas apenas às demonstrações.

A demonstração revela as subjacentes relações lógicas entre afirmações, de modo que nenhum número de testes quase-empíricos ou a intuição pura seriam capazes de realizar. A demonstração é, assim, uma ferramenta para transformar um conjunto de resultados conhecidos em um sistema dedutivo de axiomas, definições e teoremas. 
Ao longo de sua história, a Matemática convergiu para uma sistematização dedutiva cada vez mais rigorosa, na medida em que seus resultados foram se tornando cada vez mais abstratos e menos relacionados ao mundo da experiência concreta. Se Os Elementos, de Euclides, no século III a.C., iniciaram a tradição da sistematização dedutiva, foi no século XIX de nossa era que a Matemática começou a experimentar um processo de sistematização dedutiva muito mais radical, a que costumamos chamar de axiomatização. De Villiers (1986 ${ }^{8}$ apud De Villiers, 2001) aponta algumas vantagens da sistematização do conhecimento matemático (que entendemos que se aprofundam ainda mais numa axiomatização):

- possibilidade de identificar inconsistências, argumentos circulares e hipóteses ocultas;

- unificação e simplificação de teorias matemáticas;

- possibilidade de transferir uma estrutura teórica completa para outros objetos, independentemente de seu significado sensível;

- emergência de sistemas dedutivos alternativos, eventualmente mais econômicos ou mais amplos que os já existentes.

$\mathrm{Na}$ educação básica, avaliamos que não se pode esperar que as demonstrações sejam utilizadas como instrumentos de axiomatização da matemática, uma vez que, via de regra, o conhecimento matemático dos alunos ainda não está suficientemente desenvolvido para tal. A correlação entre diferentes teorias e sistemas dedutivos exige um grau bastante alto de metacognição com relação ao conhecimento matemático.

Por outro lado, no âmbito pedagógico dos cursos de graduação e pós-graduação, vemos que os materiais didáticos (e muitas vezes, as aulas), mais que comunicar os resultados, sistematizam o conhecimento matemático de modo dedutivo. O contato com esses materiais, somado à ausência de uma discussão mais abrangente acerca da demonstração nos cursos de licenciatura, poderá nos ajudar a explicar, mais adiante, a visão apresentada por alguns professores de que provas e demonstrações não são temas pertinentes à matemática escolar.

Embora não tenhamos esgotado as possíveis funções da prova em matemática, acreditamos que as cinco funções elencadas - convencimento/validação, explicação, descoberta, comunicação e sistematização - permitem vislumbrar diferentes contextos em que

\footnotetext{
${ }^{8}$ DE VILLIERS, M. D. The role of axiomatization in mathematics and mathematics teaching. RUMEUS Studies in mathematics education $\mathbf{n}^{0}$ 2. Stellenbosch University, 1986.
} 
as provas são significativas e nos quais, portanto, elas poderiam ser exploradas na matemática escolar. Para finalizar esta seção, vamos expor um quadro, adaptado de Houdebine (1990, p. 16), que, acreditamos, ajuda a organizar algumas dessas ideias, com vistas ao trabalho em sala de aula (Figura 6).

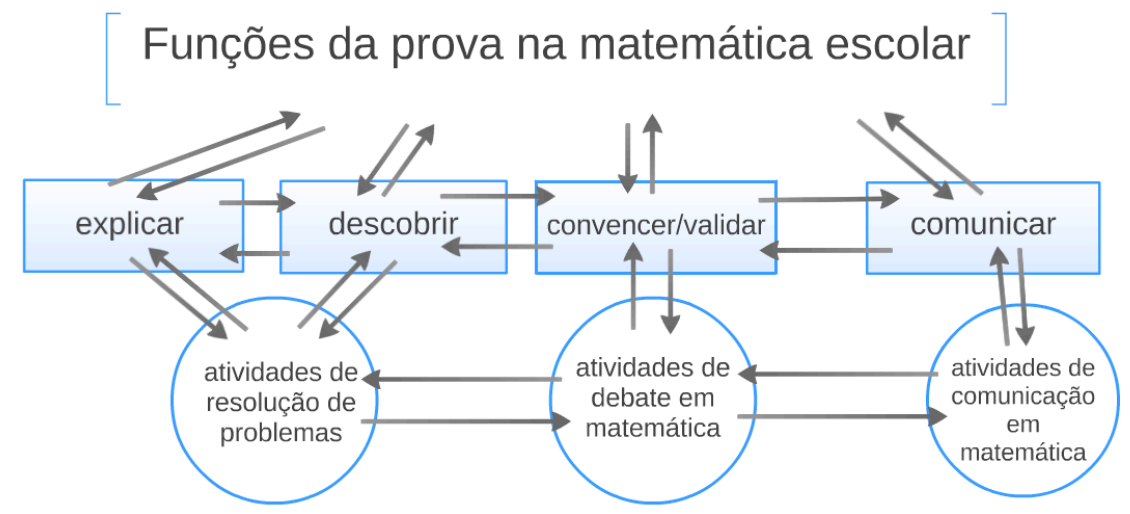

Figura 6 


\section{O papel da demonstração na Matemática}

Nossa experiência como aluna de graduação, pós-graduação e mestrado no Instituto de Matemática e Estatística da Universidade de São Paulo (IME-USP) nos dá uma comprovação pessoal e empírica de que a ideia de demonstração é basilar na matemática acadêmica. Não é exagero dizer que os livros-texto, as aulas e as avaliações se organizam em torno dessa noção e de uma sistematização dedutiva do conhecimento matemático. Uma vez que nem sempre a metodologia de ensino aplicada se pauta na resolução de problemas e no debate (que, naturalmente, engendrariam conjecturas e a necessidade de validação) e que, de modo geral, a autoridade de professores e autores basta para convencer os alunos da validade dos resultados, a função da demonstração tende a ser de comunicação e sistematização do conhecimento.

Ainda que o mesmo se repita em outros meios acadêmicos, essa verificação seria insuficiente para compreender o papel da demonstração na Matemática, pois não se pode reduzi-la ao que se ensina e aprende em cursos de graduação e pós-graduação. Na academia, se produz matemática, num contexto de verdadeira investigação científica. Mas, como vimos na seção 1.3, também nesse contexto a demonstração é muito importante, podendo assumir, além das já citadas, as funções de validação, explicação ou descoberta.

Muitas citações e depoimentos de grandes matemáticos apontam essas funções e, principalmente, corroboram a importância central da demonstração, sem a qual a Matemática se descaracterizaria. Citamos, como exemplo, o livro A formação da matemática contemporânea, em que, examinando os objetos e métodos da Matemática, Jean Dieudonné faz suceder a uma seção chamada "O nascimento das noções pré-matemáticas" uma que se chama "A ideia de demonstração". Isso sugere que é a partir da demonstração que nasce a Matemática tal como a conhecemos hoje, e o conteúdo do livro reitera essa ideia.

Nesses termos, parece interessante analisar o panorama histórico que moldou a Matemática dessa forma, mas convém fazer uma ressalva a respeito da nomenclatura. Dissemos, no Capítulo 1, que uma prova constitui uma demonstração quando é aceita por uma comunidade matemática. Essa é uma definição bastante subjetiva, uma vez que os critérios de aceitação numa comunidade matemática podem variar. Na matemática acadêmica atual, uma demonstração contém processos prioritariamente dedutivos, e é essa visão que adotamos na próxima seção. 


\subsection{Breve panorama histórico da noção de demonstração na Matemática}

Como todas as ciências, a Matemática busca a verdade e formas de validá-la. Tão aceita e aparentemente tão banal, essa afirmação implica uma importante dificuldade filosófica, que é a própria noção de verdade. Optar ou mesmo problematizar a opção por uma dada concepção geral de verdade ultrapassa enormemente o escopo deste trabalho. Por outro lado, para lograr algum êxito, qualquer ciência precisa estabelecer critérios que permitam distinguir o que é verdadeiro do que é falso. No caso da matemática, faz-se essa distinção por meio de demonstração. Assim, no que se segue, a concepção de verdade subjacente a diversos momentos históricos da matemática tem um papel central, ainda que não seja discutida diretamente.

Apesar do lugar destacado que a demonstração ocupa hoje na Matemática, seu percurso histórico é pouco documentado (PIETROPAOLO, 2005, p. 51). Segundo Garnica (1996), uma das razões para isso é que, sendo tomada pelos matemáticos como natural, ela não era problematizada a priori.

Mesmo com pouca documentação específica, a historiografia tradicional refere-se à Grécia Antiga como um divisor de águas no que tange à forma da Matemática como uma ciência dedutiva. Entre outros povos, como os antigos egípcios (aproximadamente 3000 a.C.), por exemplo, os processos dedutivos em matemática são esporádicos, e ela não parece apoiar-se em nenhuma base teórica sólida. Para eles, a matemática parece ter sido antes uma ferramenta pragmática para resolver problemas cotidianos como cálculos comerciais, medição de terras, confecção de calendários etc. Desse modo, pode-se inferir que a eficácia dos resultados para os fins a que se destinavam era o principal critério de validação do conhecimento (PIETROPAOLO, 2005, p. 51). Já na matemática praticada na Índia no século XII de nossa era, a exatidão do desenho era considerada uma prova em geometria (ARSAC, 1987), o que está longe de constituir uma demonstração que atenda ao rigor da atual Matemática.

Segundo Arsac (1987), a distinção entre prova e demonstração é particularmente útil para uma investigação histórica sobre o tema, pois permite atribuir aos gregos a invenção da demonstração, sem negar a seus predecessores as demais formas de prova. De certa forma, isso equivale a reconhecer na Grécia Antiga a formação de uma comunidade matemática que pela primeira vez teria tomado a validação do conhecimento como objeto de reflexão. De fato, 
é consenso que os gregos, especialmente no que tange à geometria, não só validavam dedutivamente seus resultados, como usaram demonstrações para organizar seu conhecimento matemático acumulado (função de validação, comunicação e sistematização). Assim, cabe investigar primeiramente como a demonstração surgiu na matemática grega.

A despeito de serem figuras históricas imprecisas, a tradição atribui papel de relevo a Tales de Mileto [ca. 624-548 a.C.] e a Pitágoras de Samos (ca. 580-500 a.C.] no surgimento da ideia de demonstração:

A proposição agora conhecida como teorema de Tales ${ }^{9}$ - que um ângulo
inscrito num semicírculo é um ângulo reto - pode ter sido aprendida por
Tales durante suas viagens à Babilônia. No entanto, a tradição vai mais
longe e lhe atribui uma espécie de demonstração do teorema. Por isso Tales
foi frequentemente saudado como o primeiro matemático verdadeiro -
originador da organização dedutiva da geometria. [...] Não há documento
antigo que possa ser apontado como prova desse feito, no entanto, a tradição
é persistente. O mais perto que se pode chegar de evidência digna de
confiança é uma menção datando de 1000 anos depois do tempo de Tales.
Um discípulo de Aristóteles chamado Eudemo de Rodes (viveu por volta de
320 a.C.) escreveu uma história da matemática. Essa perdeu-se, mas, antes
de desaparecer, alguém resumiu ao menos uma parte dela. O original desse
resumo também se perdeu, mas durante o quinto século de nossa era,
informação extraída do sumário foi incorporada pelo filósofo neo-platônico
Proclus (410-485) nas páginas iniciais de seu Comentário sobre o primeiro
livro de Os elementos, de Euclides. Após observações introdutórias sobre a
origem da geometria no Egito, o Comentário de Proclus diz que Tales
"primeiro foi ao Egito e de lá introduziu esse estudo na Grécia. Descobriu
muitas proposições ele próprio e instruiu seus sucessores nos princípios que
regem muitas outras, seu método de ataque sendo em certos casos mais
geral, em outros, mais empírico" (BOYER, 1974, p. 34-35).

Nesse excerto, há muitas informações dignas de nota, dentre as quais destacamos duas. Primeiramente, a de que as provas dedutivas são vistas pela tradição como características determinantes para que a atividade matemática se constitua como ciência - por isso Tales teria sido saudado como "o primeiro matemático verdadeiro". Com os gregos, a matemática teria começado a se transformar numa ciência hipotético-dedutiva. Em segundo lugar, pode-se inferir que a inserção de provas dedutivas (portanto, intelectuais) na matemática grega não foi absoluta ou abrupta, mas parcial e gradativa - o método de ataque de Tales teria sido "em certos casos mais geral, em outros mais empírico".

\footnotetext{
${ }^{9}$ Evidentemente, o referido teorema não é aquele usualmente dado nos livros didáticos de matemática brasileiros de ensino fundamental II sob o mesmo título.
} 
Quanto a Pitágoras, a história é ainda mais nebulosa, eivada de lendas. Sabe-se que ele fundou uma ordem secreta que ficou conhecida como escola pitagórica. Essa escola assemelhava-se mais a uma seita mística que a uma academia de ciências, mas uma de suas principais características era que seus membros atribuíam ao estudo da matemática e da filosofia o desenvolvimento da base moral para a conduta. Para eles, a matemática estava mais relacionada ao amor à verdade que às exigências da vida prática (BOYER, 1974, p. 36). A descrição dessas características sugere que a busca da verdade poderia ter levado os pitagóricos a sofisticar os procedimentos de demonstração iniciados por Tales, mas a documentação histórica deixa muitas lacunas a esse respeito:

Dizia-se que o lema da escola pitagórica era "Tudo é número". Lembrando que os babilônios tinham associado várias medidas numéricas às coisas que os cercavam, desde os movimentos nos céus até o valor de seus escravos, podemos perceber nesse lema uma forte afinidade com a Mesopotâmia. Mesmo o teorema a que o nome de Pitágoras ainda está ligado muito provavelmente veio dos babilônios. Sugeriu-se, como justificativa para chamá-lo teorema de Pitágoras, que foram os pitagóricos os primeiros a dar uma demonstração dele; mas não há meios de verificar essa conjectura. As lendas de que Pitágoras teria sacrificado um boi [...] ao descobrir o teorema são implausíveis, tendo em vista as regras vegetarianas da escola. Além disso, são repetidas, com idêntica incredibilidade, em conexão com vários outros teoremas (BOYER, 1974, p. 37).

Mesmo considerando as imprecisões e incertezas documentais, parece razoável admitir que a introdução da demonstração na atividade matemática deve-se aos gregos e tenha ocorrido pelos tempos de Tales e Pitágoras. Mas que motivos levaram a isso? As citadas características da escola pitagórica dão algumas indicações, mas não se pode dizer que expliquem a contribuição de Tales ou de outros tantos que, embora com menos destaque, certamente participaram desse processo. Arsac (1987) expõe uma tese internalista e outra externalista para o desenvolvimento da noção de demonstração na Grécia Antiga. Segundo a tese externalista, muito usual, a ascensão da matemática a ciência hipotético-dedutiva deve-se à transposição das regras de debate da vida política da Grécia Antiga para a atividade matemática. Sobre esse ponto, encontram-se muitas referências como, por exemplo:

Sabe-se que, desde o século $\mathrm{V}$ [a.C.], os pensadores gregos se haviam tornado mestres na articulação do discurso numa série de deduções lógicas, como testemunham os fragmentos das obras dos sofistas, assim como os diálogos de Platão. Haviam descoberto que esses raciocínios podiam tomar como objeto a atividade humana, qualquer que ela fosse, e, em particular, as regras da aritmética e da geometria, das quais a maior parte provinha sem dúvida das civilizações egípcia e babilônica. Serão as demonstrações que ligarão os teoremas em si (DIEUDONNÉ, 1990, p. 47-49). 
A partir do momento em que, na vida comum, o debate e argumentação se tornaram fundamentais, as técnicas de persuasão e a reflexão sobre a argumentação começaram a despertar interesse. Dentre as técnicas de persuasão, as regras de demonstração e o apelo a uma lógica que busca o verdadeiro, própria do saber teórico, passaram a ter especial destaque, e quem soubesse persuadir sempre poderia convencer os outros de que sua tese era verdadeira. Em sentido oposto, no entanto, essa tentação ao ceticismo deu origem a um esforço para mostrar que verdade e verossimilhança são coisas diversas (ROQUE, 2012, p. 95-96).

Porém, segundo Arsac, a tese puramente externalista seria contraditória com o princípio da economia ecológica de Bourdieu, segundo o qual nunca se mobiliza mais do que o necessário para resolver os problemas impostos pela prática. Demanda-se, assim, uma tese internalista, que buscará na própria matemática as causas do surgimento da demonstração. Que problema torna necessária a introdução da demonstração na prática matemática da Grécia Antiga? Segundo o autor, a resposta pode estar num problema que é contemporâneo ao surgimento da demonstração: o problema da incomensurabilidade. Primeiramente, façamos uma breve revisão desse que é talvez o problema mais conhecido da história da matemática. Depois, com o auxílio de Arsac, esboçaremos uma síntese entre as teses externalista e internalista.

Segundo Boyer (1974, p. 53, grifo do original), “era um artigo de fé fundamental do pitagorismo que a essência de tudo, na geometria como nas questões práticas e teóricas da vida do homem, pode ser explicado em termos de arithmos, ou das propriedades intrínsecas dos inteiros e suas razões". Entretanto, uma descoberta seria contraditória com esse pressuposto: os inteiros e suas razões não pareciam suficientes para descrever propriedades muito simples da geometria. Tomando um quadrado de lado unitário e sua diagonal, não se pode encontrar um segmento que coubesse um número inteiro de vezes em ambos. De forma mais geral, isso equivale a dizer que o lado e a diagonal de um quadrado são segmentos incomensuráveis ou, em termos modernos, que as medidas do lado e da diagonal de um quadrado não podem ser ambas expressas por números racionais.

Recuperando as ideias de Balacheff e de Lakatos, Arsac afirma que a mera percepção de uma contradição não implica o germe de sua superação. Assim, as teses internalista e externalista teriam de se articular para explicar a forma como os gregos encaminharam esse problema, o que terá concorrido para o surgimento da demonstração tal como a entendemos.

Boyer afirma que as circunstâncias em que o problema da incomensurabilidade foi percebido pela primeira vez são tão incertas quanto a época em que ocorreu. 
Tradicionalmente, supõe-se que tenha surgido a partir do já citado exemplo do lado e da diagonal do quadrado, em conexão com o resultado que hoje conhecemos como teorema de Pitágoras. Mas há outras teses, como a de que essa percepção se deu a partir do estudo das diagonais de um pentágono regular, que formam outro pentágono regular, cujas diagonais formam um terceiro pentágono regular e assim indefinidamente. O que se sabe é que Aristóteles (séc. IV a.C.) se refere a uma demonstração da incomensurabilidade da diagonal de um quadrado com seu lado que se baseia na distinção entre pares e ímpares. Assim, a dúvida suscitada pelo problema da incomensurabilidade parece ter sido superada por meio de uma demonstração. Em linguagem atual, essa demonstração, bastante conhecida, seria algo como o que segue.

Sejam $d$ e $l$ os comprimentos da diagonal e do lado de um quadrado, respectivamente. Suponhamos que sejam comensuráveis, isto é, que a razão $d / l$ seja um número racional e igual a $p / q$, com $p$ e $q$ inteiros primos entre si. Como a diagonal forma com dois lados do quadrado um triângulo retângulo isósceles, então $l^{2}+l^{2}=d^{2}$ (e já estaria demonstrado o teorema "de Pitágoras"?). Logo, $2 q^{2}=p^{2}$, de onde sai que $p^{2}$ é par e que, portanto, $p$ é par. Não tendo fator comum com $p, q$ deve ser ímpar. Porém, fazendo $p=2 k$, acabamos concluindo, por raciocínio análogo, que $q$ é par. Assim, ou admitimos que um inteiro pode ser simultaneamente par e ímpar, ou $d$ e $l$ não são comensuráveis. Rejeitada a primeira possibilidade, restou aos gregos aceitar que os números inteiros e suas razões não bastavam para descrever nenhuma propriedade geométrica.

Além do problema da incomensurabilidade, esses matemáticos se propuseram outros, sobretudo em geometria. Alguns deles, surgidos por volta do século V a.C. e formulados para ser resolvidos com régua e compasso, mostraram-se refratários às abordagens da época e ficaram conhecidos como problemas clássicos: a duplicação do cubo, a quadratura do círculo e a trissecção do ângulo. Não entraremos em pormenores, mas certamente a investigação acerca desses problemas concorreu para o avanço dos métodos matemáticos gregos, incluindo a organização dedutiva.

Dieudonné (1990, p. 49) cita uma célebre passagem da República, de Platão, que testemunha esse modo de organização:

Aqueles que se ocupam da geometria, da aritmética e das ciências desse gênero admitem o par e o ímpar, as figuras, três espécies de ângulos [...]. Essas coisas, dão-nas por sabidas, e, quando as usam como hipóteses, não acham que ainda seja necessário prestar contas disso a si mesmos nem aos 
outros, uma vez que são evidentes para todos. E, partindo daí e analisando todas as fases, e tirando as consequências, atingem o ponto a cuja investigação se tinham abalançado.

Muito se pode extrair dessa passagem, e voltaremos a ela oportunamente. Por ora, cumpre apenas constatar que a demonstração - e mais, o levantamento das hipóteses de partida - já era um procedimento comum entre os matemáticos gregos à época de Platão.

Com o desenvolvimento da Lógica por Aristóteles (384-322 a.C.), essa forma de proceder é reforçada, e fica estabelecida a primazia da lógica dedutiva:

[...] [Aristóteles] vislumbra a necessidade da organização das proposições nas hipóteses iniciais, logicamente necessárias, e nas proposições dedutíveis a partir delas, tratando especificamente de estruturar as possíveis deduções, as inferências legítimas. Está atento às condições que considera necessárias para tais inferências (MACHADO, 2001, p. 21).

$\mathrm{Na}$ matemática, essa organização do conhecimento em proposições necessárias e preposições dedutíveis é fixada, de uma vez por todas por volta de 300 a.C., na famosa obra Os elementos, de Euclides.

Acerca da figura histórica de Euclides, pairam muitas dúvidas, inclusive sobre seu local de nascimento, que, às vezes, é referido como sendo Alexandria. Segundo Boyer (1974, p. 74), "é conhecido como Euclides de Alexandria, porque foi chamado para lá ensinar matemática. Da natureza de seu trabalho, pode-se presumir que tivesse estudado com os discípulos de Platão, senão na própria Academia".

Os elementos são constituídos por treze volumes, que condensam e organizam a maior parte da matemática grega precedente. Mais que seu conteúdo, interessa-nos agora a forma como se organizaram esses livros. Segundo Arsac (1987), o programa empreendido por Euclides envolve:

- a definição dos entes matemáticos como objetos ideais, independentes da experiência sensível, com a ajuda de axiomas e outras definições, anteriores;

- enunciados gerais (teoremas, proposições...) que estabelecem as afirmações verdadeiras para os entes matemáticos;

- demonstrações que provam as afirmações precedentes baseando-se unicamente em axiomas, definições e regras da lógica, especialmente a do terceiro excluído. 
A crítica de Os elementos é pródiga em apontar as falhas de Euclides nesse programa. Porém, a importância do que foi alcançado é inegável e inestimável: essa obra imprimiu à matemática, simultaneamente, um padrão de rigor para a validação do conhecimento e um meio de comunicá-lo e sistematizá-lo. Ainda que isso não se tenha expressado de forma homogênea na atividade matemática desde então, dava-se ali um ponto de referência inequívoco.

Segundo Arsac (1987), a partir do momento em que renuncia à experiência física e aos sentidos para definir os objetos da matemática e validar suas afirmações, inaugura-se um processo de axiomatização que exige a explicitação das regras de manipulação a que se podem submeter esses objetos e essas afirmações. O método disponível baseia-se em deduções, de modo que essa passa a ser uma característica das demonstrações. Mas enunciar isso não dispensa do debate de uma série de questões como, por exemplo: de onde vêm as regras de dedução que permitem a manipulação desses objetos e dessas afirmações? Segundo o autor, os gregos estavam cientes das dificuldades desse debate. Também se podem levantar as dificuldades de explicitar completamente as hipóteses que servem de base aos teoremas, uma vez que os matemáticos não podem usar senão a linguagem da familiaridade (BOURDIEU, 1980, p. $153^{10}$ apud ARSAC, 1987), que se constrói sobre visões implícitas compartilhadas numa comunidade, o que dificulta perceber uma série de falhas: os axiomas implícitos ou a referência a figuras, por exemplo:

Todavia, é apenas o nosso treino nas exigências da axiomática moderna que
nos faz notar essas imperfeições. Sem contar com a espinhosa questão do
postulado das paralelas [...] não parece que tenham sido feitas muitas críticas
dessa natureza ao texto de Euclides ou aos trabalhos de seus sucessores antes
do século XVI. Uma longa habituação parece ter enfraquecido nos
geômetras a consciência da coragem que representa a passagem do mundo
dos objetos sensíveis ao dos objetos inteligíveis. Enquanto essa consciência é
muito visível em Platão e Aristóteles, ficamos surpreendidos por ver
pensadores tão profundos como Descartes ou Pascal [...] proclamarem
vigorosamente a "verdade evidente" dos axiomas da geometria
(DIEUDONNÉ, 1990, p. 53).

É interessante notar a contraposição entre as visões de Descartes ou Pascal, para os quais, segundo Dieudonné, os axiomas da geometria eram "verdades evidentes", e a visão de Platão, resgatando uma citação da República que extraímos antes de Dieudonné: "Essas coisas, dão-nas por sabidas, e, quando as usam como hipóteses, não acham que ainda seja necessário prestar contas disso a si mesmos nem aos outros, uma vez que são evidentes para

\footnotetext{
${ }^{10}$ BOURDIEU P. Le sens pratique. Collection: Le sens commun, Paris: Ed. de Minuit, 1980.
} 
todos". Platão toma certas coisas como hipóteses, não como verdades. Para Dieudonné, justamente a reflexão sobre a natureza dessas hipóteses e sobre os entes a que se aplicam constitui o que se convencionou chamar de problema dos fundamentos da matemática.

As críticas a Os elementos, que foram feitas especialmente no século XIX, fazem parte de um movimento que busca mais rigor na matemática pelo exame de seus fundamentos, de modo que não são dirigidas às inferências de Euclides, mas aos fundamentos em que se assentam. Em outras palavras, as críticas se dirigem principalmente aos axiomas, às definições e às noções comuns arroladas em Os elementos.

Essas críticas estão ligadas ao surgimento das chamadas geometrias não euclidianas, a partir do século XVIII, quando, por exemplo, o matemático italiano Giovanni Girolamo Saccheri estuda as consequências da negação do quinto postulado de Euclides, conhecido como postulado das paralelas. No século XIX, de forma independente, outros matemáticos (Lobachevsky e Bolyai, por exemplo) chegaram a outras geometrias consistentes a partir da negação do quinto postulado (EVES, 1995, p. 541-542). Assim, passou-se de uma geometria que, embora já fosse abstrata, se apoiava fortemente em nossa experiência sensível, a uma multiplicidade de geometrias estranhas a essa mesma experiência, porém logicamente consistentes:

O desenvolvimento dessas geometrias não euclidianas que não tinha como suporte o mundo empírico ou, pelo menos, "um" mundo ainda que o platônico, conduziu os matemáticos à supervalorização da concepção abstrata, não interpretada, dos sistemas formais. Isso influenciou poderosamente a própria concepção de verdade em Matemática, bem como a questão de sua relação com uma realidade empírica externa ou com seu mundo autônomo, de necessidades próprias. E a legitimação das teorias formais passou a ocorrer muito menos com centro num suposto ou esperado isomorfismo entre o mundo matemático e o mundo empírico, muito mais com base nas teorias formais que se produziam, independentemente de elas admitirem, de imediato, interpretações empíricas. A consistência exigida refere-se a que na mesma teoria formal não seja possível demonstrar uma proposição e, simultaneamente, a sua negação (MACHADO, 2001, p. 34).

Dessa afirmação, depreende-se que, a partir daí, mais que validar esta ou aquela proposição individualmente, as demonstrações passaram a concorrer para validar teorias matemáticas inteiras. Isso fica evidente não só na busca da consistência de uma teoria, mas também na de sua completude. Simplificadamente, diz-se que uma teoria formal é completa se é possível demonstrar qualquer enunciado (expresso de acordo com as normas estabelecidas 
na teoria) ou sua negação. Ou seja, uma teoria formal é completa se é possível decidir sobre a verdade ou falsidade de todo enunciado formulado dentro dela.

No final do século XIX, os matemáticos alemães Moritz Pasch e David Hilbert dedicaram-se a melhorar o programa de Euclides relativo à geometria. Hilbert propõe objetos (pontos, retas e planos) e relações primitivas (incidência, estar entre, congruência), que não define, e um conjunto de axiomas (mais amplo que o de postulados e axiomas de Euclides). ${ }^{11}$ Para evitar que a experiência sensível se imponha sub-repticiamente às inferências em geometria, Hilbert propôs algo que soa como uma brincadeira: que se substituam as palavras ponto, reta e plano, respectivamente, por mesa, cadeira e caneca. Desse modo, o primeiro dos axiomas por ele proposto seria "duas mesas distintas pertencem a uma mesma cadeira e a uma só". Essa espécie de brincadeira revela uma desvinculação da matemática do conteúdo semântico de suas afirmações, restando a estrutura lógica entre entes sem significado sensível. (Impossível não fazer um paralelo com as exigências do processo que, segundo Balacheff (1987), permite passar das provas pragmáticas às intelectuais: descontextualização, despersonalização e destemporalização.)

O movimento encabeçado por Hilbert passou a ser identificado como Formalismo e pretendia obter um sistema formal que englobasse não apenas a geometria, mas a própria Matemática, unificando todos os seus ramos. As demonstrações seriam, metaforicamente, os elos dessa unificação. Porém, em 1931, o programa formalista é gravemente desestabilizado, a partir de um artigo do matemático alemão Kurt Gödel, intitulado "Sobre as proposições indecidíveis dos principia mathematica e Sistemas Correlatos", em que demonstra que uma teoria formal suficientemente abrangente não pode ser ao mesmo tempo consistente e completa. Isso significa que, se a teoria for consistente (como sempre se busca, em primeiro lugar), haverá necessariamente proposições cuja verdade ou falsidade não se pode demonstrar.

O teorema da incompletude, como ficou conhecido o resultado de Gödel, é realmente espantoso, e suas consequências filosóficas são tão profundas que muitos afirmam que ainda não foram totalmente absorvidas, dentro ou fora da Matemática. Para o programa formalista, foi um duro golpe. Machado (2001, p. 38) explica as consequências desse golpe:

Para tentar resistir ao fato inconteste da existência de proposições bemformadas que não se pode decidir se são verdadeiras ou falsas, o formalismo

\footnotetext{
11 Euclides distingue axiomas e postulados, sendo os primeiros referentes a fatos mais gerais. Atualmente, embora ainda se adote essa distinção, esses termos são muitas vezes tomados como sinônimos.
} 
fincou pé em um último reduto: o questionamento do próprio conceito de verdade. E foi com entusiasmo incontido que desembocou, por volta de 1934, na concepção de verdade de Tarski.

O polonês Alfred Tarski localiza o problema da verdade na linguagem. A verdade seria uma propriedade das sentenças. Uma teoria que trata de objetos $\mathrm{O}_{i}$ é vista como linguagem (linguagem objeto), dentro da qual é possível estabelecer sentenças $\mathrm{S}_{\mathrm{i}}$, que dizem respeito a alguns dos objetos $\mathrm{O}_{\mathrm{i}}$. Mas a verdade de uma sentença $\mathrm{S}_{\mathrm{k}}$ específica só pode ser decidida numa linguagem de ordem superior (metalinguagem), cujos objetos sejam as sentenças $\mathrm{S}_{\mathrm{i}}$. Embora Tarski tenha formulado esses princípios para linguagens formais, damos um exemplo em línguas naturais, para ilustrar a ideia central. Vejamos as sentenças abaixo:

- "Esta caneta é vermelha" é uma sentença verdadeira se e somente se esta caneta é vermelha.

- "This pen is red" é uma sentença verdadeira se e somente se esta caneta é vermelha.

Em ambos os casos, a sentença maior envolve uma menor. No primeiro, a sentença menor e a maior estão enunciadas na mesma língua e, por isso, temos a impressão de obviedade. Porém, no segundo caso, o inglês faz o papel de linguagem objeto, enquanto o português faz o de metalinguagem, dentro da qual se pode atribuir algum sentido à veracidade de "This pen is red".

No entanto, a passagem de uma linguagem a uma metalinguagem não tem fim, de modo que não se poderia formalizar toda a Matemática por métodos finitos. Assim, a solução de Tarski representa uma flexibilização do programa formalista, mas não exatamente seu êxito. Nas palavras de Machado (2001, p. 39), “o infinito, no entanto, permanece-lhes atravessado na garganta".

De toda forma, a noção de verdade na Matemática atual tem grande influência do movimento Formalista, portanto, sem nenhuma pretensão de andar emparelhada com a noção de verdade do mundo sensível (embora isso se verifique num número surpreendente de casos). A verdade matemática de uma proposição é sempre relativa a sua coerência com um conjunto de hipóteses (axiomas, postulados, definições, noções primitivas...), que não são verdadeiras ou falsas em si mesmas, mas são admitidas de acordo com necessidades e conveniências dos problemas de que trata determinada teoria.

O panorama histórico geral que traçamos aqui certamente deixou uma série de lacunas importantes e tocou apenas superficialmente assuntos de extrema dificuldade. Entretanto, 
lançou alguma luz a parte das questões que nos propomos a investigar. As provas não só caracterizam a atividade matemática como transformaram-na em ciência na exata medida em que se foram transformando em demonstrações, tal como são concebidas pelos padrões atuais de rigor acadêmico.

Isso, entretanto, não significa que se possa depreciar a matemática praticada por grupos humanos sob outros padrões de rigor. Ao contrário, como vimos, a noção de verdade e rigor vigentes na Matemática são fruto de contingências históricas e a transformação da Matemática numa ciência hipotético-dedutiva não foi nem breve, nem simples, nem linear, mesmo considerando apenas a tradição ocidental.

No próximo tópico, exploramos alguns episódios particulares, descritos pela historiografia da Matemática, para aprofundar as percepções trazidas pelo panorama traçado e, principalmente, experimentar nossa compreensão e o alcance teórico das referências expostas no Capítulo 1, a despeito de serem, em sua maioria, oriundas da Educação Matemática. Ou, melhor dizendo, exatamente por serem oriundas da Educação Matemática, parece interessante experimentar seu alcance num estudo histórico-epistemológico.

\subsection{O problema da validação em episódios da História da Matemática}

\subsubsection{O conhecimento empírico dos pitagóricos}

Impulsionados pela valorização da lógica, os pensadores gregos criaram muitas teorias para explicar a formação do universo não por meio de mitos, mas de elementos que pudessem ser abordados racionalmente como a água, o ar, o fogo, o número - este último, eleito pelos pitagóricos como o fundamento de todas as coisas. Tudo no mundo se poderia explicar por um arranjo numérico, porque todas as coisas gozariam de duas propriedades: seriam delimitadas (finitas) e poderiam ser separadas umas das outras. Portanto, tudo seria contável, e as propriedades aritméticas dos números associados às coisas constituiriam o próprio ser das coisas.

Certamente, essa não é uma concepção pragmática de número, que não tem aí nenhuma função prática, mas metafísica. Mas tampouco há aí uma noção abstrata de número, pelo menos não matematicamente abstrata, como explica Roque (2012, p. 104): 
Os pitagóricos, contudo, embora sejam vistos como primeiros a considerar o número do ponto de vista teórico, e não apenas prático, não possuíam, de fato, uma noção de número puro. Diferentemente de Platão, os pitagóricos não admitiam nenhuma separação entre número e corporeidade, entre seres corpóreos e incorpóreos. Logo, não é lícito dizer que o conceito pitagórico de número fosse abstrato. De certo ponto de vista, dado seu caráter espacial e concreto, poderíamos afirmar que os números pitagóricos não eram os objetos matemáticos que conhecemos hoje, isto é, entes abstratos. Os números figurados dos pitagóricos eram constituídos de uma multiplicidade de pontos que não eram matemáticos e que remetiam a elementos discretos: pedrinhas organizadas segundo uma determinada configuração.

Daí os conhecidos números figurados - triangulares, quadrados, pentagonais etc. -, sobre os quais é possível formular uma diversidade de proposições. Tomemos uma delas como exemplo: a soma dos $n$ primeiros inteiros ímpares é $n^{2}$. Que fariam os pitagóricos para validar essa proposição?

Sobre os pitagóricos, Roque (2012, p. 137) afirma que "sua aritmética era indutiva e não continha provas". Analisemos essa falta de provas à luz da categorização proposta por Balacheff.

Já sabemos que o conceito de número não era abstrato, mas ligava-se à configuração concreta de uma coleção de pontinhos. Então, o conceito de número era indissociável de uma linguagem visual que permitiria expressar essa proposição como na Figura 7, que vemos usualmente em livros de História da Matemática.

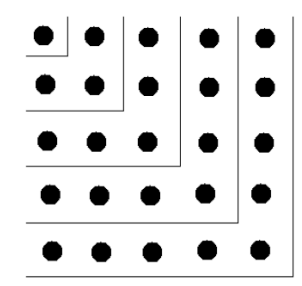

Figura 7

Podemos imaginar diversos procedimentos para construir o quadrado seguinte a partir do que está dado na figura. Aqui, destacamos um procedimento capaz de indicar a razão pela qual, a partir de um número quadrado de lado $n$ - 1 , a soma do ímpar seguinte (o $n$-ésimo) leva ao número quadrado seguinte, que é especificamente $n^{2}$. 


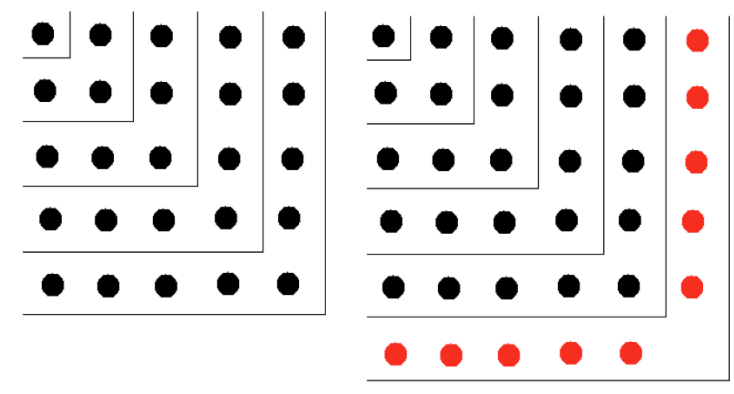

Figura 8a

Figura $8 b$

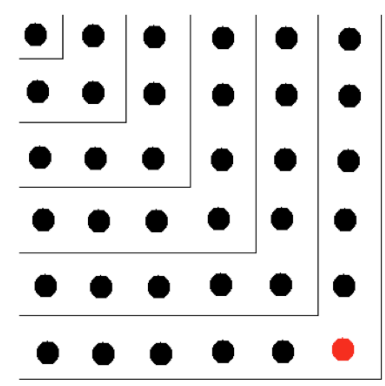

Figura 8c

As Figuras $8 \mathrm{a}, 8 \mathrm{~b}$ e $8 \mathrm{c}$ representam as etapas de um processo que pode ser repetido indefinidamente: ao quadrado dado (Figura 8a), acrescenta-se um número que é o dobro de seu lado, portanto, um número par (Figura 8b). Mas é preciso acrescentar mais um pontinho para completar o quadrado seguinte (Figura 8c), de modo que, de um número quadrado ao seguinte, acrescenta-se sempre um número ímpar (o dobro do lado do quadrado anterior mais um). Chamando de $(n-1)$ o lado do quadrado inicial, nossa argumentação visual conduz ao seguinte resultado: $(n-1)^{2}+[2(n-1)+1]=(n-1)^{2}+(2 n-1)=n^{2}$. Fazendo o caminho inverso, podemos ir desconstruindo os números quadrados da mesma forma, de modo que $n^{2}$ $=(n-1)^{2}+(2 n-1)=(n-2)^{2}+(2 n-3)+(2 n-1)=\ldots=1+3+\ldots+(2 n-3)+(2 n-1)$.

Mesmo que os pitagóricos não tenham elaborado essa prova em linguagem verbal ou algébrica, tal como fizemos aqui, o processo construtivo de um número quadrado a partir do anterior torna evidente a proposição e pode ser encarado como uma prova pragmática. Indo um pouco mais longe, esse processo construtivo aproxima-se bastante do exemplo genérico, na categorização proposta por Balacheff. Embora seja um processo fundamentalmente empírico - como não poderia deixar de ser, dado o status concreto da noção de número dos pitagóricos -, a questão da generalidade não é negligenciada, pois, ainda que por meio da linguagem visual, esse processo construtivo explicita as razões da validade da proposição, considerando o objeto ao qual se aplica (um número quadrado particular) apenas um representante da classe dos números quadrados. Ainda assim, a própria natureza da linguagem visual adotada não permite se descolar completamente da exibição desse representante particular.

Finalizando a análise da categorização dessa prova visual, encontramos na tese de doutorado de Balacheff (1988) uma discussão exatamente sobre ela, mas sem esse contexto histórico. A discussão trata da linguagem adotada na prova e de sua relação com a natureza do conhecimento em jogo. Segundo ele, o que acabamos de analisar é uma prova por exposição (ostension), no sentido de que ela é a exposição das operações, ações e seus resultados, que 
não são diferenciados nem articulados em palavras. Nesse caso, isso indica, para Balacheff, que também a proposição que ela prova está num nível de conhecimento pragmático, que ele relaciona à noção de teorema-em-ação, expressão com que Gerard Vergnaud designa os saberes que um sujeito mobiliza na resolução de problemas (daí a validade, daí o teorema), sem, no entanto, ser capaz de enunciá-los.

Balacheff afirma que a eficiência dessa forma de prova reside na capacidade do interlocutor de reconstruir as razões implícitas na evidência exposta, o que coincide exatamente com aquilo que procuramos fazer.

Assim, esse breve exemplo mostra que, ainda na Grécia Antiga - considerada tradicionalmente o berço da organização dedutiva da matemática -, podemos ter provas mais rudimentares. Sobre o status da prova e seu nível de rigor, forçosamente incidem a racionalidade vigente (o caráter metafísico associado aos números figurados), a linguagem (visual, no caso), os saberes (a noção de número) e as particularidades da situação (que, no caso, permite o acesso direto à experiência).

\subsubsection{Descoberta e validação em Arquimedes}

O episódio que examinaremos nesse tópico ilustra como os processos de descoberta e validação do conhecimento matemático podem obedecer a métodos e a critérios de rigor bastante diversos. Trata-se da exposição do processo de descoberta e da demonstração dada por Arquimedes, no século III a.C., para certos problemas de obtenção de áreas e volumes.

Arquimedes é o mais conhecido dos matemáticos gregos do período pós-euclidiano. Assim, a matemática de sua época já havia sofrido a influência da organização dedutiva de $O s$ elementos, e vários procedimentos específicos de demonstração já estavam bem estabelecidos. Entretanto, a obra de Arquimedes não se limita a eles:

Não se percebe em seus trabalhos uma preocupação em usar nem em defender um método de tipo axiomático, e a forma como expõe seus resultados não parece ter sofrido influência dos Elementos. Sem se restringir a nenhuma determinação a priori, Arquimedes usa métodos não euclidianos, como a neusis, mesmo quando uma construção com régua e compasso é viável. Conforme sugere Knorr, ao invés de estender ou generalizar a estrutura axiomática da matemática, Arquimedes parecia estar mais preocupado em comunicar novas descobertas relativas à resolução de problemas geométricos. Em alguns prefácios, toma o cuidado de distinguir os procedimentos heurísticos de descoberta dos procedimentos de demonstração (ROQUE, 2012, p. 197-198). 
O excerto reforça a ideia de que, em Os elementos, a validação tem uma função sistematizadora, dado que tudo leva a crer que tal obra não é produto de uma pesquisa "viva", mas um compêndio do conhecimento matemático acumulado na época. Mas, na matemática original e cheia de vitalidade de Arquimedes, não se poderia esperar que a descoberta fosse ofuscada pelas imposições de rigor para a sistematização do conhecimento. Ainda assim, Arquimedes pertencia a uma comunidade matemática bem estabelecida e trabalhava em acordo com a conduta de seus contemporâneos.

A chamada demonstração por dupla redução ao absurdo é praxe nas demonstrações arquimedianas. Trata-se de um procedimento de prova que consiste em assumir as duas formas possíveis da desigualdade entre duas grandezas e, a partir daí, por absurdo, concluir que tais grandezas devem ser iguais. Por exemplo, em seu livro A esfera e o cilindro, Arquimedes demonstra, por meio desse procedimento, que o volume da esfera $\left(V_{e}\right)$ está para o volume do cilindro $\left(V_{c}\right)$ que a circunscreve assim como 2 está para 3. Na linguagem atual, o que Arquimedes faz nessa demonstração é supor que $V_{e}<2 V_{\mathrm{c}} / 3$ e, a partir de uma série de deduções, apoiando-se em resultados já conhecidos na época, mostrar que essa suposição conduz a um absurdo. Depois, faz o mesmo partindo da suposição de que $V_{e}>2 V_{c} / 3$. Então, de acordo com os princípios da lógica aristotélica, só lhe resta admitir que $V_{e}=2 V_{c} / 3$.

Fica claro que estamos frente a uma demonstração plenamente ajustada aos padrões de rigor da matemática grega da época, como atesta a correspondência entre Arquimedes e seus contemporâneos (AABOE, 1984). Mas ficam ocultos os processos heurísticos que levam à conjectura de partida, sem a qual não se pode construir a demonstração:

\footnotetext{
Essa falta de elemento analítico e heurístico na geometria grega codificada, isto é, uma exibição aberta da maneira como os teoremas foram inicialmente suspeitados, antes de ser demonstrados, foi lamentada no século XVII, quando os matemáticos estavam lutando por criar uma nova análise matemática (o cálculo e suas ramificações). O matemático inglês Wallis (1616-1703) chegou mesmo a acreditar que os gregos escondiam deliberadamente seus caminhos de descoberta (AABOE, 1984, p. 118).
}

No entanto, a suspeita de Wallis mostrou-se equivocada, pelo menos com relação a Arquimedes. Em 1906, foi encontrado um códice contendo uma obra de Arquimedes intitulada $O$ método. Escrito em forma epistolar a Eratóstenes de Alexandria, o livro começa assim: 
Saudações.

Enviei-lhe em outra ocasião alguns teoremas descobertos por mim, meramente os enunciados, deixando-lhe a tarefa de descobrir as demonstrações então omitidas. [...] Vendo em você um dedicado estudioso, de considerável eminência em Filosofia e um admirador da pesquisa matemática, julguei conveniente escrever-lhe para explicar as peculiaridades de um certo método pelo qual é possível investigar alguns problemas de Matemática por meios mecânicos. [...] Certas coisas primeiro se tornaram claras para mim pelo método mecânico, embora depois tivessem de ser demonstradas pela Geometria, já que sua investigação pelo referido método não conduzia a provas aceitáveis. Certamente é mais fácil fazer as demonstrações quando temos previamente adquirido, pelo método, algum conhecimento do que sem esse conhecimento. [...] Estou convencido de que ele será valioso para a Matemática, pois pressinto que outros investigadores da atualidade ou do futuro descobrirão, pelo método aqui descrito, outras proposições que não me ocorreram (ARQUIMEDES apud ÁVILA, 1986, p. 31).

O que seria o tal método mecânico? E por que Arquimedes considera que ele não conduz a provas aceitáveis, embora claramente o valorize do ponto de vista heurístico?

O método mecânico citado por Arquimedes consiste essencialmente num procedimento de investigação geométrica que dá aos objetos matemáticos um tratamento físico, baseado nos resultados que ele mesmo desenvolveu em suas obras Sobre o equilibrio das figuras planas I e Sobre o equilibrio das figuras planas II, em que define a lei das alavancas: uma alavanca estará em equilíbrio se o produto do peso A pela distância a entre o fulcro e o ponto de suspensão de A for igual ao produto do peso $\mathrm{B}$ por sua distância $\mathrm{b}$ ao fulcro, isto é, se $A . a=B . b$ (Figura 9).

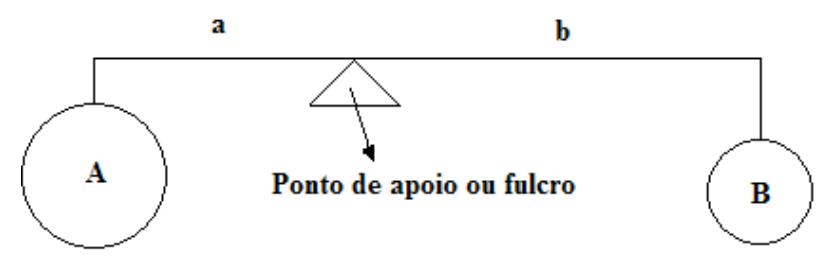

Figura 9

Uma vez enunciado esse princípio, é possível avançar na compreensão do método mecânico a partir do exemplo da investigação a respeito do volume de uma esfera.

Sejam um círculo, um triângulo e um retângulo dispostos conforme a Figura 10a, em que a reta $t$ é perpendicular à reta $s$ e cruza as três figuras. $O$ raio $r$ do círculo é fixo, mas $x$ e $y$ podem variar, conforme se translada a reta $t$ ao longo de $s$. 


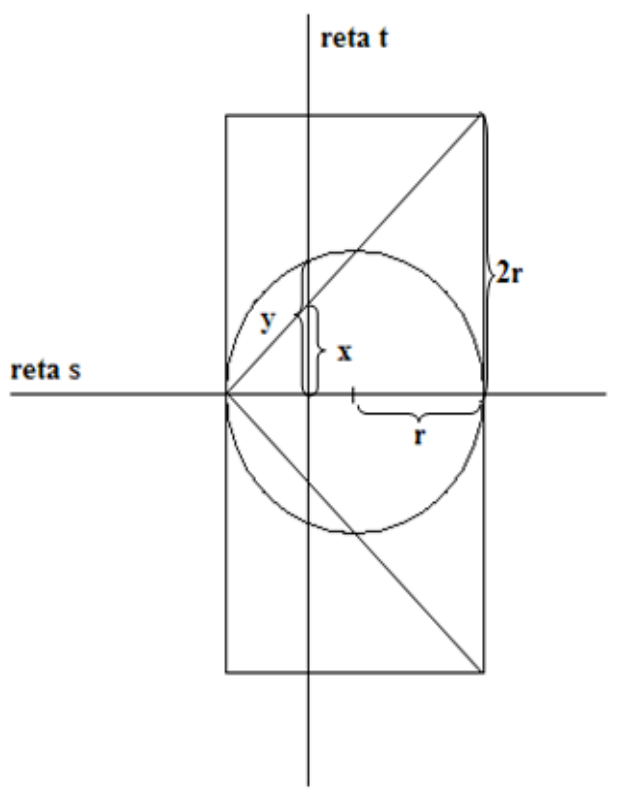

Figura 10a

Ao rotacionar as três figuras e a reta $t$ em torno da reta $s$, obtemos uma esfera, um cone, um cilindro e um plano que intercepta os três sólidos. Isso será importante mais adiante.

Nota-se que $(r-x)^{2}+y^{2}=r^{2}$, de onde segue que $x^{2}+y^{2}=2 r x$. Então, $\frac{\pi x^{2}+\pi y^{2}}{\pi(2 r)^{2}}=\frac{x}{2 r}$.

Segundo o método mecânico, esta última expressão é interpretada como se $x$ e $2 r$ fossem distâncias, e $\pi x^{2}, \pi y^{2}$ e $\pi(2 r)^{2}$ fossem áreas (proporcionais aos pesos) de três discos circulares (Figura 10b).

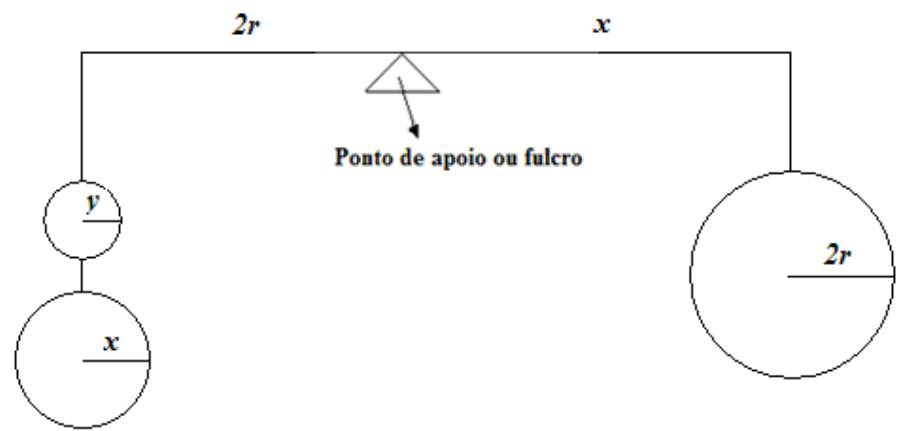

Figura $10 \mathrm{~b}$

É evidente que $x$ pode variar entre 0 e $2 r$. Isso permite imaginar o plano determinado pela rotação da reta $t$ varrendo os três sólidos de rotação sem que isso afete o equilíbrio entre os discos. 
O passo determinante, entretanto, vem a seguir: Arquimedes considera que cada sólido é composto pelo somatório de suas secções planas. Nesse caso, o cilindro se equilibra com a esfera e o cone, desde que estes estejam a uma distância $2 r$ do fulcro de uma alavanca, enquanto o centro de gravidade do cilindro deve estar a uma distância $r$ desse fulcro (Figura $10 \mathrm{c})$.

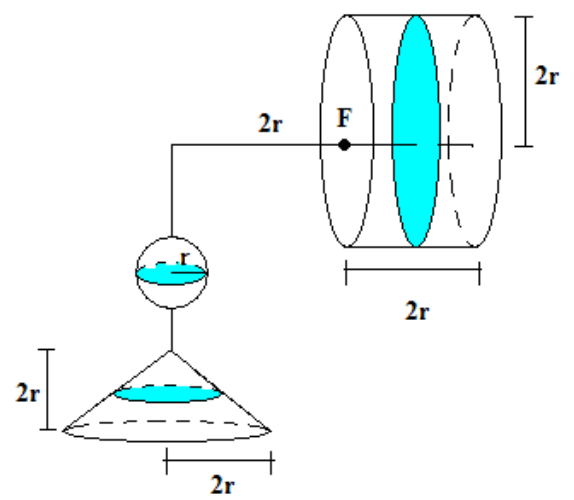

Figura 10c

A partir do exposto, é fácil concluir que $V_{e}=\frac{4}{3} \pi r^{3}$. É claro que, para Arquimedes, como para todos os gregos da Antiguidade, medir não era fornecer um número, mas comparar, de modo que esse fato foi enunciado como já expusemos: o volume da esfera está para o volume do cilindro que a circunscreve assim como 2 está para 3.

Mas, membro de uma comunidade matemática com suas próprias exigências de rigor, Arquimedes não pode aceitar esses procedimentos de descoberta como demonstração. Primeiramente, está a questão da extrapolação do caráter abstrato dos objetos matemáticos, considerando que possam incidir sobre eles propriedades mecânicas relativas a centros de gravidade, alavancas e condições de equilíbrio. Depois, há hipóteses "composicionais", que envolvem considerar áreas compostas por retas paralelas a uma reta dada e volumes, por planos paralelos a um plano dado.

Apesar de as hipóteses do primeiro tipo estarem bem fundamentadas pela teoria estática desenvolvida pelo próprio Arquimedes, sua aplicação aos objetos geométricos é obviamente incorreta, em sentido estrito. Pode-se dizer que Arquimedes se permitiu uma licença mecânica (por analogia a licença poética) para investigar os resultados que lhe interessavam. 
Quanto às hipóteses do segundo tipo, elas tocam num ponto nevrálgico da matemática grega, que, desde os paradoxos de Zenão, se viu diante de problemas que só seriam resolvidos muitos séculos mais tarde. De acordo com o status dos saberes matemáticos à época, era logicamente insustentável considerar os objetos geométricos compostos por "indivisíveis".

O método de descoberta de Arquimedes pode ser considerado uma prova para ele mesmo, pois claramente serviu a seu próprio convencimento. Por outro lado, certamente não era uma demonstração, de acordo com os critérios de rigor da comunidade matemática a que ele pertencia. Que tipo de prova seria o método mecânico de Arquimedes? Como poderíamos enquadrá-lo na tipologia de provas proposta por Balacheff, por exemplo?

A complexidade desse método torna bastante difícil enquadrá-lo em alguma das categorias. Com relação ao problema da generalidade, Arquimedes refere apenas características geométricas e físicas gerais dos objetos em tela, mas não parece lícito dizer que se trata de um experimento puramente mental. Os objetos matemáticos são tratados como objetos físicos, ainda que isso seja feito de um modo teórico, não efetivamente empírico. Arquimedes aplica a esses hipotéticos objetos físicos conhecimentos oriundos de uma teoria bem definida, mas que, por referir-se a objetos físicos, está, de alguma forma, apoiada em evidências empíricas.

A função dessa prova "mecânica" parece ser de explicação e de descoberta, enquanto a função da demonstração por dupla redução ao absurdo é de validação e de comunicação do conhecimento junto à comunidade matemática.

Mais que categorizar o tipo de prova constituída pelo método mecânico de Arquimedes ou analisar suas funções, o exame desse episódio concorre para lembrar que, apesar do papel central da demonstração, a Matemática não se reduz às demonstrações ou à organização dedutiva. Os problemas do mundo físico (e suas soluções) são fontes inesgotáveis de ideias e intuições sobre as quais ela também se constrói.

\subsubsection{Eficácia versus rigor em Cavalieri}

Segundo Balacheff (1987), a eficácia é uma exigência prática, enquanto o rigor é uma exigência teórica. $\mathrm{Na}$ realidade, num contexto prático, a prova é a própria eficácia - o que, do 
ponto de vista didático, obriga-nos a extrapolar esses contextos, em algum momento, se quisermos levar os alunos a erigirem sua linguagem e seus saberes a outros patamares.

Segundo Roque (2012), foram sobretudo questões mistas, de natureza não puramente matemática, mas de significação técnica ou física, que impulsionaram a investigação de problemas geométricos no século XVII. Nesses casos, a validação do conhecimento matemático também apresenta formulações híbridas e é muito discutida entre os matemáticos.

É esse o contexto do resultado mais conhecido de Bonaventura Cavalieri, o método dos indivisiveis, que consta do tratado Geometria indivisibilibus continuorum, publicado em 1635. Desse método, podemos extrair duas proposições, uma relativa à determinação de áreas e outra relativa à determinação de volumes. Ambas circulam até hoje em textos de Matemática com a denominação Princípio de Cavalieri. Em linguagem atual e numa forma levemente generalizada, essas proposições corresponderiam aproximadamente ao que segue:

a) Se duas regiões planas são tais que toda reta secante a elas e paralela a uma reta dada determina nessas regiões segmentos de reta cuja razão é constante, então a razão entre as áreas dessas regiões é essa mesma constante.

b) Se dois sólidos são tais que todo plano secante a eles e paralelo a um plano dado determina nesses sólidos seções cuja razão é constante, então a razão entre seus volumes é essa mesma constante.

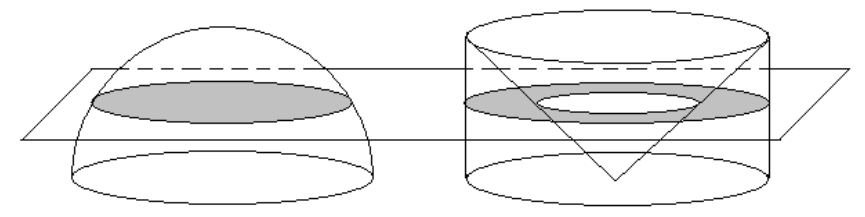

Figura 11

Como se vê, o Princípio de Cavalieri permite obter a área de determinada região plana por sua comparação com outra, de área conhecida (o mesmo com relação ao volume de um sólido, o que corresponde à proposição b), configurando um grande trunfo para resolver problemas de áreas e volumes. Por exemplo, o volume de um hemisfério pode facilmente ser obtido pela comparação com outro sólido (obtido retirando um cone de um cilindro) (Figura 11).

Mas como Cavalieri obteve seu método? E como o validou?

O que sabemos é que sua base conceitual se apoia na noção de indivisíveis. Segundo Cavalieri, uma figura plana é constituída de infinitos segmentos de reta paralelos, e, 
analogamente, um sólido é formado por infinitas "fatias" planas paralelas. Esses segmentos de reta e essas fatias planas são os tais indivisíveis. Apesar do forte apelo intuitivo dessa explicação, ela é facilmente refutável e foi alvo de críticas em sua época: se segmentos de reta não têm espessura, como podem produzir a segunda dimensão de uma figura plana? Analogamente, como a terceira dimensão de um sólido - digamos, sua altura - pode ser produzida pelo acúmulo das espessuras nulas de figuras planas? A dificuldade parece insuperável.

Dito de outro modo, Cavalieri foi capaz de dar uma explicação, mas não uma prova da validade de seu método dos indivisíveis, menos ainda uma demonstração. Seu argumento foi refutado. Mas ele tem um trunfo valioso: a eficácia do método. Sua aplicação permite obter resultados sabidamente corretos (ou plausíveis) em problemas de áreas e volumes. Essa eficácia fez com que, apesar de quaisquer críticas, diversos matemáticos continuassem não só aplicando o método dos indivisíveis, mas buscando aperfeiçoá-lo:

\begin{abstract}
Além de Roberval, Fermat e Pascal utilizaram o método dos indivisíveis para encontrar áreas delimitadas por diferentes curvas. No entanto, foram propostas modificações importantes, constituindo-se um novo método dos indivisíveis no qual a área não era decomposta em um número infinito de linhas, mas concebida como a soma de um número indefinido de retângulos. Essa soma difere da área original por uma quantidade que pode ser tornada menor que qualquer quantidade dada. Surgiu, assim, uma nova maneira de calcular áreas por meio da aproximação de uma área por retângulos infinitamente finos, e essa ferramenta podia ser aplicada a qualquer figura curvilínea (ROQUE, 2012, p. 348).
\end{abstract}

Vê-se, portanto, que a refutação da prova associada ao método dos indivisíveis não o invalida. Balacheff (1987), influenciado por Lakatos (segundo ele mesmo), se propõe a analisar as possíveis consequências das refutações, ajudando-nos a interpretar esse fato. Ele explica que um contraexemplo pode impactar não necessariamente a conjectura, mas a prova, os saberes envolvidos, a racionalidade que subjaz a todo o processo ou o próprio contraexemplo.

É mais ou menos o que vemos aqui. No caso, não se trata de um contraexemplo que refuta a conjectura, mas da refutação lógica da prova associada a um método. Essa refutação preservou o método, ao mesmo tempo em que acabou por modificar significativamente os saberes matemáticos a ele relacionados. A versão atual para o método dos indivisíveis é o cálculo integral, por meio do qual, aliás, é possível formular uma demonstração rigorosa (para os padrões atuais) do Princípio de Cavalieri. 


\section{0 lugar reservado à prova na matemática escolar}

Neste capítulo, analisamos o lugar reservado à prova matemática no contexto escolar (em termos potenciais e também atuais), comparando-o com o que ela tem na própria Matemática, analisado no capítulo anterior. Consideramos as especificidades de cada contexto, mas sem ignorar o processo dialógico que pode e deve ser estabelecido entre eles.

Nossa experiência docente na educação básica nos convenceu de que a prova (não necessariamente rigorosa) é um elemento central no ensino e na aprendizagem da matemática, tanto no ensino fundamental quanto no médio. Ela está no cerne de diferentes tipos de prática, de acordo com suas várias funções, e:

- pode ser o modo como o professor expõe resultados matemáticos aos alunos;

- interfere na forma como o professor organiza uma sequência didática para que certas escolhas de definições, resultados, contextos e materiais apoiem conjecturas e inferências desejáveis;

- permite ao professor explicar as razões da validade dos resultados e, por vezes, sua origem histórica;

- está no centro das discussões coletivas acerca de conjecturas formuladas pelos próprios alunos, que devem ser validadas ou refutadas;

- é uma etapa importante na resolução de um problema pelos alunos, que precisam validar ou refutar sua solução;

- às vezes, é indissociável do processo heurístico que leva à solução de um problema;

- pode orientar o modo como os alunos comunicam a resolução de um problema;

- ajuda os alunos a compreenderem o processo de construção do conhecimento matemático;

- eventualmente, leva os alunos a fazerem descobertas imprevistas.

Essas percepções, bastante favoráveis ao trabalho com a prova matemática na educação básica, são tributárias de nossa formação e de nossa experiência docente. Os referenciais consultados para o desenvolvimento desta dissertação concorreram para explicitar essas percepções e, além disso, as corroboraram. De fato, no campo de pesquisa da Educação Matemática, parece ser consensual a importância e a pertinência do trabalho com argumentação e prova desde o ensino fundamental: 
No capítulo 3, apresentamos a existência de algumas pesquisas de âmbito internacional envolvendo argumentações e provas e, apesar da diversidade de enfoques e de aspectos contraditórios, todas defendem a possibilidade e a necessidade de desenvolver um trabalho sobre esse tema no ensino fundamental e médio. Também não encontramos estudos que claramente explicitassem opiniões contrárias a esse propósito (PIETROPAOLO, 2005, p. 131).

É importante esclarecer que esse consenso não nos parece um retorno às tendências formalistas descritas a seguir:

Até o final da década de 1950, o ensino de Matemática no Brasil, salvo raras exceções, caracterizava-se pela ênfase às ideias e formas da Matemática clássica, sobretudo ao modelo euclidiano e à concepção platônica da Matemática. O modelo euclidiano caracteriza-se pela sistematização lógica do conhecimento matemático a partir de elementos primitivos (definições, axiomas e postulados). Essa sistematização é expressa através de teoremas e corolários que são deduzidos dos elementos primitivos (FIORENTINI, 1995, p. 5).

Ou seja, a tendência formalista se caracteriza por uma identificação entre os princípios do ensino de matemática na educação básica e os princípios que organizam a própria Matemática, desconsiderando, em grande medida, as especificidades e os propósitos do contexto escolar. Por causa dessa identificação, a demonstração se destacava, sobretudo em geometria, pela tradição euclidiana. Porém, dentro dessa tendência, o ensino ficava centrado no professor, que expunha o conteúdo por desenvolvimentos teóricos na lousa, restando aos alunos um papel passivo diante do conhecimento - o que, de certo modo, está de acordo com a visão platônica da preexistência desses conhecimentos. Não se problematizavam o desenvolvimento cognitivo dos alunos, suas necessidades intelectuais ou suas motivações frente à Matemática.

Esse tipo de prática não está associado ao consenso, na Educação Matemática, sobre a importância do trabalho com argumentação e prova desde o ensino fundamental. A postura de muitos pesquisadores da Educação Matemática atual, com a qual nos alinhamos, é a de que a prática formal da demonstração não precisa ser uma meta do currículo de matemática da educação básica (isso seria um "bônus"), mas que é mais importante que os alunos cultivem uma prática de argumentação e prova que, estando em consonância com sua racionalidade em desenvolvimento, seja significativa e mantenha-os atentos à necessidade da validação do conhecimento. 
Também é importante acrescentar que o consenso sobre a importância do trabalho com argumentação e prova não significa que não se reconheçam as dificuldades que ele implica. Pelo contrário, o acentuado crescimento da linha de pesquisa a respeito de argumentação e prova no campo da Educação Matemática nas últimas décadas evidencia muitas dificuldades por enfrentar e também divergências sobre como fazê-lo. Segundo Pietropaolo (2005), as tentativas desse enfrentamento têm originado diversos caminhos de pesquisa, tais como:

- aspectos curriculares, como organização de tarefas, objetivos e métodos;

- aspectos sociais, culturais e cognitivos que influem no processo de ensino e aprendizagem da prova;

- formação inicial e continuada de professores;

- características do conhecimento matemático e a disciplina Matemática nas escolas.

Observamos que, apesar do crescimento dessa linha de pesquisa no Brasil, muitos dos principais autores que trabalham com o tema são estrangeiros. Se, por um lado, isso não invalida a transposição de suas conclusões epistemológicas ou cognitivas para o contexto brasileiro, por outro, as motivações desses trabalhos derivam de problemas bastante diferentes dos nossos. Balacheff, por exemplo, logo no início de seu artigo, menciona sua preocupação com as dificuldades do trabalho com o currículo de matemática francês:

A noção de demonstração ocupa um lugar de destaque no ensino de Matemática na França a partir do terceiro ano do secundário. Sua aprendizagem apresenta dificuldades ligadas à passagem de uma matemática "prática", caracterizada pela ação e pela observação, nos dois primeiros anos do ensino secundário, para uma matemática mais teórica, caracterizada justamente por conta da introdução da demonstração $\left(1987\right.$, p. 147). ${ }^{12}$

Essa preocupação com a ruptura da passagem a uma matemática "com provas" parte do reconhecimento do destaque da noção de demonstração no ensino de Matemática na França, o que está muito distante da perspectiva brasileira. Em nossa experiência na formação continuada, não temos ouvido dos professores nada a respeito das dificuldades que enfrentam com relação à prova matemática em sala de aula e, além disso, percebemos certa resistência ao assunto. Isso é que nos chama atenção e é o que constitui nosso problema central.

\footnotetext{
12 "La notion de démonstration occupe une place importante dans l'enseignement des mathématiques en France où elle apparaît lors de la troisième année de l'enseignement secondaire, en classe de quatrième. Son apprentissage présente des difficultés importantes. Il est classique de signaler que ces difficultés sont d'abord liées au passage d'une mathématique 'pratique', caractérisée par l'action et l'observation dans le cours des deux premières années de l'enseignement secondaire, à une mathématique plus théorique justement caractérisée par l'introduction de la démonstration" (BALACHEFF, 1987, p. 147, tradução nossa).
} 
Antes de avançar, convém ressaltar que não discutiremos esse problema de um ponto de vista quantitativo, mas qualitativo. A maior parte dos professores brasileiros deixa de lado o trabalho com a prova matemática em sala de aula? Não temos condições de responder a essa pergunta, mas não encontramos nenhum indício de que o trabalho com a prova matemática na atual escola brasileira seja expressivo ou que os professores brasileiros o valorizem. Ao contrário: embora não tenhamos encontrado dados efetivos sobre a ausência da prova matemática na escola brasileira das últimas décadas, em muitos dos textos brasileiros parece haver um consenso tácito sobre essa ausência. Além disso, consideramos que resultados como o do PISA, citado na Introdução desta dissertação, podem ser reflexo de uma tendência de ensino de matemática que não dá destaque ao trabalho com argumentação e provas.

\subsection{A prova matemática na educação básica brasileira: do destaque ao "ostracismo"}

Em vista do exposto, na investigação da problemática da prova na matemática escolar brasileira, a primeira pergunta que se coloca é: como passamos da tendência formalista, em que a demonstração tinha lugar de destaque (ainda que, em muitos sentidos, de um modo que consideramos negativo), à ausência de um trabalho expressivo com a prova em matemática?

Em primeiro lugar, é importante ressaltar que, embora a tendência formalista tenha tido muita importância no ensino de matemática e tenha sido dominante na primeira metade do século passado, isso não significa que, no mesmo período, não houvesse outras tendências. Segundo Fiorentini (1995), o ensino dessa matemática clássica, pautada no formalismo, era garantido às elites. Por outro lado, o ensino de matemática às classes menos favorecidas sobretudo aos alunos das escolas técnicas - privilegiava o cálculo e as aplicações pragmáticas, com uma abordagem mais mecânica. Parece certo que, nesse ensino mais pragmático, as demonstrações tivessem um papel menor, mas os dados são insuficientes para inferir que não houvesse aí nenhuma prática relativa à argumentação ou à prova. Seja como for, é interessante notar que, em sua representação social, a demonstração acaba se vinculando a uma escola elitista, que será duramente criticada mais tarde, não apenas por não levar em conta o desenvolvimento cognitivo de crianças e jovens, mas também, justamente, por esse caráter excludente.

Desde a década de 1930, ganhou força no Brasil o movimento de reforma da educação conhecido como Escola Nova, que fez muitas críticas às tendências formalistas no ensino de 
Matemática (FIORENTINI, 1995). Tendo alcançado uma parcela importante da intelectualidade brasileira, esse movimento defendia a universalização da escola pública, laica e gratuita e preconizava que o ensino levasse em conta, prioritariamente, não as características das disciplinas, mas a natureza do desenvolvimento biológico e psicológico das crianças e jovens. Segundo Pietropaolo (2005), a Reforma Francisco Campos, de 1931, nitidamente influenciada pela Escola Nova, fazia restrições ao uso de demonstrações e admitia que, no âmbito escolar, deveriam ter lugar as generalizações indutivas e intuitivas e que os alunos deveriam ter um papel ativo no aprendizado, a partir de atividades experimentais e da manipulação de materiais concretos.

Na Escola Nova, a concepção do processo de ensino-aprendizagem é a empíricoativista (FIORENTINI, 1995), que enfatiza menos as estruturas internas da matemática e mais sua relação com as ciências empíricas e com problemas oriundos do cotidiano. Assim, a matemática valeria mais por sua aplicabilidade que pela organização dedutiva, e se aplicam em seu ensino a modelagem matemática e a resolução de problemas.

Apesar da influência da Escola Nova, pelo menos no que concerne à Geometria, o currículo prescrito pela Reforma Francisco Campos não abandona o ideal da demonstração formal, embora enfatize a necessidade de precedê-la por um trabalho de caráter intuitivo e experimental:

[...] partindo da intuição viva e concreta, a feição lógica crescerá, pouco a pouco, até atingir, gradualmente, a exposição formal; ou, por outras palavras, os conhecimentos serão adquiridos primeiro por experimentação e pela percepção sensorial e, depois, lentamente, pelo raciocínio analítico. Assim, quanto à Geometria, o estudo demonstrativo formal deve ser precedido de um curso propedêutico, destinado ao ensino intuitivo, de caráter experimental e construtivo. Ao iniciar o estudo dedutivo de Geometria, o primeiro cuidado será o de fazer sentir ao aluno o que significa uma demonstração utilizando-se, como ponto de partida, dos próprios fatos inferidos intuitivamente no curso preparatório. É ainda a partir das intuições que se deve estabelecer o conjunto de axiomas fundamentais $\mathrm{e}$ indispensáveis à exposição lógica da Geometria. Nesse estudo ter-se-ão em vista: a) o enunciado das proposições, sua demonstração e aplicações; b) a compreensão e a justa apreciação do raciocínio dedutivo; c) o valor da exposição clara e sucinta do encadeamento lógico, das ideias e da memória matemática. Obtido pela Geometria plana o adestramento suficiente nas demonstrações dedutivas, a feição lógica pode ser menos acentuada na Geometria a três dimensões (BICUDO, $1942^{13}$ apud PIETROPAOLO, 2005, p. 102).

\footnotetext{
${ }^{13}$ BICUDO, J. C. O ensino secundário no Brasil e sua atual legislação: 1931 a 1941. São Paulo: [s.n.], 1942.
} 
É interessante notar que, em muitos aspectos, o ideário da Escola Nova tem pontos comuns com posicionamentos bastante atuais dentro da Educação Matemática, que, a despeito de circularem já há bastante tempo, ainda não encontram ressonância em muitos dos contextos educacionais vigentes. De nossas leituras, pudemos inferir que, a despeito da adesão da intelectualidade, o alcance desse ideário também não foi tão majoritário em sua época, nem nas escolas de elite - onde o formalismo conduzia a prática de ensino de matemática -, nem nas escolas das classes menos favorecidas - onde a matemática era abordada de forma mecanizada e pragmática.

A partir da década de 1950, um novo movimento veio impactar a educação matemática brasileira. Trata-se do Movimento da Matemática Moderna (MMM), que surge no âmbito internacional como uma resposta à percepção da defasagem entre o ensino de ciências e matemática e as demandas científico-tecnológicas da sociedade industrial.

Segundo Fiorentini (1995), os objetivos do MMM eram:

- unificar os vários ramos da matemática pela introdução de temas como a teoria dos conjuntos, a teoria das estruturas algébricas e o estudo das relações e funções;

- enfatizar os aspectos estruturais e lógicos da disciplina, "em lugar do caráter pragmático, mecanizado, não justificado e regrado, presente, naquele momento, na matemática escolar";

- levar à matemática escolar o processo de algebrização que ajudou na fundamentação lógica da Matemática contemporânea.

Com relação ao movimento da Escola Nova, o MMM propõe o retorno à tendência formalista, agora modernizada. Em vez do modelo euclidiano, a via de formalização é constituída pelas estruturas algébricas e pela linguagem da Matemática contemporânea. Com isso, esperava-se que a apreensão da estrutura subjacente à Matemática capacitasse os estudantes a transporem-na para outros domínios.

Pietropaolo (2005, p. 105) ilustra como o MMM vê a prática da demonstração na matemática escolar comentando uma proposta curricular do estado de São Paulo da década de 1970:

No Estado de São Paulo, foram elaborados os Guias Curriculares para o Ensino do Primeiro Grau, cujos princípios estavam ainda bastante arraigados no Movimento da Matemática Moderna. Esses princípios não enfatizavam, conforme comentamos no capítulo 1, o ensino da Geometria euclidiana e 
suas demonstrações. Apesar disso, relativamente à demonstração, convém ressaltar que para a $7^{\mathrm{a}}$ série é indicado, nos guias, o "início do emprego do raciocínio hipotético-dedutivo na Geometria”, mas não são discutidas possíveis maneiras de trabalhar essa área da Matemática, nem propostas para desenvolver tal raciocínio.

O autor também comenta outro documento paulista, cuja finalidade era auxiliar na implantação dos referidos Guias. Chamavam-se Subsídios para Implementação do Guia Curricular de Matemática/Geometria e faziam uma crítica bastante contundente à abordagem axiomática da geometria escolar, em que podemos notar influência tanto do movimento escolanovista quanto do MMM:

[...] mais que os conteúdos tradicionais, foi a arcaica metodologia utilizada no ensino da Matemática que levou à situação quase calamitosa atingida pelo ensino dessa matéria. No que diz respeito à Geometria, então, o problema se agravou com a insistência na utilização de um pseudo-raciocínio rigoroso baseado, quase sempre, numa axiomática "furada"! Na atual era tecnológica, existe a necessidade de preparar técnicos que, mais do que conhecimentos de Matemática, utilizem habilidades desenvolvidas no estudo da mesma para a resolução de novos problemas que surgem, constantemente, em outras áreas do conhecimento (SÃO PAULO, 1978, p. 9-11 ${ }^{14}$ apud PIETROPAOLO, 2005, p. 105-106).

É interessante notar que, a despeito de seu caráter formalista, o MMM, não enfatiza as demonstrações, por estarem tradicionalmente vinculadas à geometria e ao modelo de organização euclidiano, temas que não privilegia.

A esse caldo de influências, vem juntar-se a tendência tecnicista, de origem estadunidense, que teve grande influência no Brasil entre o final da década de 1960 e o final da década de 1970:

Essa tendência fundamenta-se sociofilosoficamente no funcionalismo, para o qual a sociedade seria um sistema organizado e funcional, isto é, um todo harmonioso em que o conflito seria considerado uma anomalia e a manutenção da ordem uma condição para o progresso (FIORENTINI, 1995, p. 15).

Não surpreende, pois, que o mesmo autor refira que essa tenha sido a pedagogia “oficial” da ditadura civil-militar pós-1964. Nessa concepção, a escola passa a ter um papel importante na manutenção da ordem, e os alunos são educados para se integrar e ser competentes e úteis ao sistema. Para a prática da argumentação na matemática escolar tal

${ }^{14}$ SÃO PAULO (Estado). Secretaria da Educação. Subsídios para a implementação do guia curricular de matemática: álgebra para o primeiro grau $-5^{\mathrm{a}}$ a $8^{\mathrm{a}}$ séries. Coord. Almerindo M. Bastos e Lydia C. Lamparelli. São Paulo: SE/CENP, 1978. 
como a concebemos, essa tendência parece, de plano, particularmente negativa, uma vez que essa prática exige um processo dialético de refutações e provas dentro do qual o conflito intelectual é importante.

Fiorentini (1995) também refere que da síntese entre a tendência formalista e o MMM surge o tecnicismo formalista, em que a matemática é concebida a partir de sua estrutura formalizada, enquanto a organização do processo de ensino-aprendizagem segue o tecnicismo, e a prioridade passa a ser o treinamento de habilidades estritamente técnicas. No material didático, os conteúdos são dispostos na forma de instrução programada, em que um modelo apresentado deve ser seguido numa série de exercícios. Há grande preocupação com a linguagem e com o uso correto dos símbolos; o caráter formal se sobrepõe ao social, dando a entender que a Matemática seria uma ciência politicamente neutra e a-histórica.

Ainda na década de 1970, outra versão do tecnicismo, em vez de incluir características da tendência formalista, se opõe fortemente a ela e acaba por gerar o tecnicismo mecanicista, que reduz a matemática a um conjunto de técnicas, regras e algoritmos, sem grande preocupação com fundamentação ou prova (FIORENTINI, 1995). A matemática não é vista tanto como uma atividade humana, mas antes como produto dessa atividade, e o objetivo é tornar os alunos hábeis na resolução de exercícios e problemas padronizados.

Em qualquer das versões da tendência tecnicista, o ensino não está centrado no aluno ou no professor, mas nos objetivos instrucionais e nos métodos de ensino. Os conteúdos são vistos como informações, regras e "macetes". Professor e aluno tornam-se meros executores de um processo cuja concepção fica a cargo de especialistas. Em vista disso, o tecnicismo também parece bastante desfavorável ao trabalho com argumentação e provas em sala de aula, porque este se relaciona mais ao desenvolvimento de uma postura crítica e criativa em matemática que à apreensão de saberes factuais e procedimentais particulares. Além disso, segundo nossa leitura da obra de Balacheff, uma situação de validação é um dos principais motores para a elaboração de provas, absolutamente dispensáveis, por outro lado, em atividades como a aplicação de algoritmos ou a reprodução de soluções de problemas-tipo. Fiorentini (1995, p. 17) corrobora essa percepção:

O método japonês "Kumon" de aprendizagem da Matemática é o exemplo mais autêntico da pedagogia tecnicista. Muitos cursinhos pré-vestibulares e alguns concursos vestibulares também reforçam esse tipo de ensino. De fato, estes enfatizam apenas questões ou atividades explorando unicamente: $1^{\circ}$ ) a memorização de princípios e fórmulas; $2^{\circ}$ ) habilidades de manipulação de 
algoritmos ou de expressões algébricas; $3^{\circ}$ ) habilidades na resolução de problemas-tipo. De fato, raramente aparecem questões exigindo do aluno explicações, ilustrações, construção de modelos matemáticos que descrevam situações-problema, análises, justificativas, raciocínios dedutivos.

Outra tendência educacional importante começa a ganhar visibilidade no Brasil por volta das décadas de 1960 e 1970: o construtivismo, baseado na epistemologia genética piagetiana. O biólogo Jean Piaget (1896-1980) interessou-se ao longo de toda a sua vida pela epistemologia e procurou explicar como um sujeito aprende partindo de suas bases biológicas, concebendo a inteligência como ligada à ação e à adaptação ao meio. Para Piaget, o conhecimento não é imposto ao sujeito pelo meio e tampouco está contido no sujeito, esperando para aflorar: ele é fruto da interação reflexiva do sujeito com o meio, num processo contínuo e dialógico entre ação e adaptação, entre desequilíbrio e re-equilíbrio cognitivo.

Fiorentini (1995) chama atenção para o fato de que a tendência construtivista se opõe tanto à formalista clássica quanto à moderna, pois, para os formalistas, o conhecimento matemático poderia ser construído pelo sujeito isoladamente, sem necessidade de interação com o meio. Além disso, apesar de destacar a necessidade da ação no processo de aprendizagem, essa ação não pode ser confundida com a defendida pelos escolanovistas, que tendem a enfatizar as atividades e os materiais concretos, mas não tanto o sujeito a que se aplicam.

Ainda segundo Fiorentini (1995), na década de 1980, estabeleceram-se no Brasil diversos grupos de estudo e pesquisa autodenominados construtivistas, tendo mesmo influenciado algumas propostas curriculares, tal como a do estado de São Paulo, em 1988. De fato, a leitura dessa proposta curricular deixa bastante clara a influência do construtivismo. Por exemplo, logo na abertura da seção intitulada “As preocupações metodológicas", na proposta ao então $2^{\circ}$ grau (atual ensino médio), lê-se que "A participação do aluno na elaboração de seu conhecimento é um dos pontos fundamentais da concepção atual de aprendizagem":

Se analisarmos os currículos mais recentes, como a Proposta Curricular de São Paulo de 1988, podemos constatar diversos pontos em comum com o currículo da Reforma Francisco Campos, em especial quanto ao ensino de Geometria e às recomendações quanto às provas (PIETROPAOLO, 2005, p. 103). 
Ou seja, tal como a Reforma Francisco Campos, a proposta curricular paulista de 1988 busca um equilíbrio entre raciocínios dedutivos e indutivos e pauta o trabalho pedagógico pela manipulação de materiais concretos e de atividades planejadas. Além dessas ideias gerais, apenas há alguma explicitação a respeito de provas e demonstrações relativamente à Geometria. Isso sugere que, em certa medida, o construtivismo retoma o ideário educacional da Escola Nova, ainda que o atualize e o aprofunde, agora com base numa teoria científica a respeito da aprendizagem, que é a epistemologia genética de Piaget.

Reconhecemos na tendência construtivista um campo fecundo para um trabalho significativo com argumentações e provas no ensino de matemática, uma vez que o processo dialógico entre provas e refutações está em consonância com o modo de conceber a aprendizagem como um processo de desequilíbrio e reequilíbrio cognitivo. Além disso, como destaca Fiorentini (1995), para os construtivistas, o processo é mais importante que o produto, sendo os conteúdos meios para se desenvolverem as estruturas básicas da inteligência.

Embora significativa a partir da década de 1980 no Brasil, a adesão ao construtivismo como tendência pedagógica também suscitou diversas críticas e rejeições. Uma dessas críticas tem relação com o fato de que construtivismo se origina de uma teoria psicológica do aprendizado, mas nunca foi formalmente elaborado como uma pedagogia ou uma teoria educacional (FIORENTINI, 1995). Desse modo, essa tendência poderia gerar um efeito “psicologizante", que deixa de lado outras fontes de orientação para a prática pedagógica. Isso pode explicar, por exemplo, por que muitos dos grupos que aderiram ao construtivismo o fizeram de modo bastante radical e acabaram por colocá-lo em prática como uma didática espontaneísta, não diretiva e de não transmissão de conhecimentos. Nesse tipo de implementação do construtivismo, excluem-se do meio com o qual o sujeito interage no processo de aprendizagem os produtores históricos do conhecimento e seus produtos (no caso, os matemáticos e os conteúdos matemáticos tradicionais). Com isso, a educação perde muito de sua finalidade de inserção do sujeito na tradição. Para Fiorentini (1995), frente às críticas, o construtivismo absorveu muitas contribuições de diversas áreas do conhecimento, tais como a Sociologia, a Antropologia e a Linguística, tendo hoje pressupostos mais amplos.

Seja como for, a capacidade de penetração do construtivismo foi menos significativa do que sua importância teórica. Referindo-se à Proposta Curricular do Estado de São Paulo de 1988, que, como já citamos, sofreu claramente essa influência, Pietropaolo (2005, p. 26) testemunha a dificuldade dos professores em implementá-la: 
Como nosso trabalho na CENP envolvia os professores da rede pública estadual, percebíamos as dificuldades que esses docentes tinham na implementação de inovações curriculares. Esse fato pode ser corroborado pelo documento Análise dos relatórios, SE/CENP, 1998, que continha as análises dos pareceres dos professores que ensinavam Matemática sobre a Proposta Curricular para o $1^{\circ}$ grau (ensino fundamental), elaborados em julho/agosto de 1987. Esse documento faz referência à posição dos professores, inequívoca, de rejeição à proposta por não se sentirem em condições de incorporar as diretrizes nela contidas. ${ }^{15}$

Fiorentini (1995) discute diversas outras tendências que influenciaram o ensino de matemática no Brasil nas últimas décadas, tais como a socioetnocultural ou a histórico-crítica, por exemplo. Cada qual traz diferentes potencialidades ao trabalho com argumentação e prova nas aulas de matemática da educação básica, mas também podem ser problemáticas, dependendo da forma como são implementadas. Entretanto, nenhuma das demais tendências comentadas pelo autor parece se haver estabelecido com força suficiente para suplantar a herança das tendências discutidas de forma mais detalhada nesta seção, pelo menos no tange à prova matemática.

Assim, ao lado de nossa experiência como professora da educação básica e formadora de professores, a análise empreendida nesta seção nos leva a concluir resumidamente que:

- a tendência formalista enfatiza as demonstrações de modo negativo, por transferir diretamente para o contexto escolar problemas e critérios de rigor próprios da Matemática. As práticas pautadas nesse tipo de tendência acabaram por associar a demonstração matemática a uma escola antiquada e elitista;

- a tendência tecnicista, em suas várias vertentes, principalmente a mecanicista, praticamente elimina a importância de provar e demonstrar, pois tende a conceber a matemática como um conjunto de objetos e procedimentos estanques, e não como uma atividade humana de construção de conhecimento, dentro da qual o problema da validação ganha relevo. Essa tendência aproxima-se da educação matemática oferecida às camadas mais populares desde o início do século passado, de modo que conjecturamos que a ampliação do acesso à educação, da forma como ocorreu, talvez a tenha fortalecido;

- todas as tendências comentadas são, em diferentes medidas, expressas pelos professores - que costumam apresentar um ideário pedagógico híbrido -, mas a

\footnotetext{
${ }^{15} \mathrm{O}$ mesmo autor, ao longo de sua tese, também aponta algumas das causas desse tipo de dificuldade: a exclusão dos professores dos processos de elaboração de propostas e de decisões curriculares e o descompasso entre as orientações curriculares e a formação dos professores.
} 
possível predominância da tendência tecnicista ajudaria a explicar a falta ou a inexpressividade do trabalho com argumentação e prova na matemática escolar brasileira das últimas décadas.

\subsection{A prova matemática na formação inicial dos professores de matemática}

$\mathrm{Na}$ seção anterior, vimos como as tendências formalista e tecnicista, cada uma à sua maneira, seriam desfavoráveis a um trabalho significativo com argumentação e prova na matemática escolar. Agora, em paralelo, consideramos a análise de Pietropaolo (2005) da influência dessas mesmas duas tendências na formação inicial de professores de matemática da educação básica. Segundo o autor, a maior parte dos cursos de Matemática no Brasil seguiu o modelo iniciado na USP em 1934, em que a preocupação com a formação de pesquisadores era muito mais forte que a de docentes. Só mais tarde começaram a se distinguir os cursos de bacharelado e licenciatura. O modelo de licenciatura que predominou durante anos passou a ser conhecido como " $3+1$ " - três anos de bacharelado e um ano de complementação pedagógica, para aqueles que pretendiam lecionar.

Esse modelo não favorece a integração entre os conhecimentos matemáticos e os pedagógicos. Além disso, os três anos de formação matemática, com professores que geralmente são matemáticos profisssionais, tendem a se dar dentro de uma concepção formalista, que não distingue os objetivos da matemática acadêmica dos da matemática escolar.

\footnotetext{
Assim, não é difícil supor qual é o papel da demonstração nesses cursos, que chamaremos "formalistas". As provas rigorosas seriam um dos vetores mais importantes nessa concepção, pois elas, antecedidas dos axiomas e definições, seriam a essência da própria Matemática. Por conseguinte, os futuros professores deveriam constatar no decorrer de sua formação que as demonstrações são veículos de concepções dominantes na produção científica de Matemática (PIETROPAOLO, 2005, p. 125).
}

Numa pesquisa acerca da importância da prova rigorosa (demonstração, portanto) na formação do professor de matemática, Garnica (1996) distingue entre os formadores matemáticos e educadores matemáticos - duas leituras básicas a respeito do tema: a técnica e a crítica. Segundo ele, a leitura técnica é marcada por procedimentos bem definidos, transmissíveis, capazes de produzir resultados úteis. Assim, aqueles que tendem a fazer uma leitura técnica da importância da prova rigorosa na formação do professor acabam se detendo 
em aspectos sintáticos da demonstração e partem do pressuposto de que a função da prova é meramente validar o conhecimento, da forma mais rigorosa possível.

A leitura técnica, admitindo a prova já como prova rigorosa, exclui outras possíveis formas de rigor, porque pautada nos rígidos parâmetros da Lógica. [...] A leitura pela via técnica é estrada de mão única. É próprio da habilidade de desenvolver provas - cotidiano do matemático profissional crer na univocidade dos significados pretendida pela linguagem formalizada. [...] É pois no domínio da prática científica da Matemática - do fazer do matemático profissional - que essas concepções se desenvolvem e se perpetuam. A leitura técnica parece, então, estar filiada ao exercício profissional da Matemática (GARNICA, 1996, p. 19/21).

Podemos inferir que essa leitura técnica, portanto, seria predominante nas licenciaturas desenvolvidas em centros de pesquisa matemática, como é muitas vezes o caso das que têm lugar nas universidades públicas. Isso corrobora a visão de Pietropaolo a respeito dos "cursos formalistas". E, de acordo com tudo que já expusemos, o problema é que essa visão não favorece que o futuro professor debata, com relação à prova, outras formas de rigor que se fazem necessárias na matemática escolar. Desse modo, para que venha a desenvolver um trabalho significativo com argumentação e prova, seria necessário que esse futuro professor superasse, possivelmente de forma autônoma, o abismo entre o rigor com que a prova lhe é apresentada em sua própria formação e as reais possibilidades de argumentação de seus jovens alunos. Já a leitura crítica, apontada por Garnica, não exclui a importância da técnica, mas é crítica no sentido de que problematiza a prova, clareando seus métodos de ação e seus objetivos ocultos, por meio de abordagens históricas e filosóficas que lhe conferem maior significado e que podem subsidiar a transposição dessa prática matemática para a sala de aula.

Pietropaolo (2005) refere que, a partir de 1997, os cursos de licenciatura passam a ser regulamentados pelo Conselho Nacional de Educação, a partir de uma série de pareceres e resoluções. Por ocasião da elaboração desses pareceres e resoluções, muito se discutiu a possível identidade de um curso de licenciatura em Matemática. Dessas discussões, emergiu uma visão, de que a licenciatura deveria "romper com a dicotomia entre conhecimentos pedagógicos e conhecimentos específicos e [deveria ter sua] identidade apoiada em conhecimento matemático radicalmente vinculado ao tratamento pedagógico e histórico" (PIETROPAOLO, 2005, p. 121).

Entretanto, a implementação desse novo modelo de licenciatura precisou - e ainda precisa - negociar espaço em meio a visões, concepções e problemáticas diversas. Assim, o modelo formalista continuou sendo "uma 'meta' valorizada, embora cada vez mais difícil de 
atingir pelas condições 'de entrada' desses alunos no ensino superior, com pouco domínio dos conteúdos matemáticos tradicionalmente ensinados na educação básica” (PIETROPAOLO, 2005, p. 126). Além disso, as referidas defasagens de conhecimento "de entrada" dos alunos ingressantes nas licenciaturas podem ter concorrido para inflar o número de cursos que passaram a praticar uma formação tecnicista, com ênfase em aspectos instrumentais e procedimentais da Matemática.

É importante ressaltar, entretanto, que a discussão sobre as licenciaturas continua avançando com base na LDB 9.394/1996. Por exemplo, a partir das exigências do Conselho Nacional de Educação e das resoluções do Conselho Nacional de Educação de 2002, a USP elaborou e aprovou, em 2004, o Programa de Formação de Professores da USP (PFPUSP). A partir desse documento, a estrutura curricular da Licenciatura em Matemática no IME-USP passou por alterações que foram implementadas em 2006, com o objetivo de conferir ao curso uma identidade própria e mais orientada às necessidades do futuro professor, principalmente por meio de práticas como componentes curriculares.

Sobre a dificuldade de superar a mera superposição de disciplinas específicas, disciplinas pedagógicas e estágios nas licenciaturas, o próprio PFPUSP afirma que "um quadro como esse - tão criticado como arraigado em nossa prática formativa e em nossa cultura acadêmica - não será transformado pela força de um novo conjunto de diretrizes ou normas ou mesmo a partir de uma reforma da estrutura curricular" (PFPUSP, 2004, p. 8), mas ressalta a importância de que os mecanismos institucionais fomentem "a constante proposição de soluções inovadoras por parte de docentes" (PFPUSP, 2004, p. 8). Nesse sentido, entendemos que reformulações curriculares como as implementadas no IME-USP em 2006 são um passo significativo, que enseja maior integração entre referenciais da Matemática e da Educação Matemática.

Para a discussão de nosso tema de interesse na formação inicial do professor, essa integração é fundamental, pois, como aponta Garnica, a Educação Matemática é o campo mais propício para que se trate a prova matemática a partir de uma leitura crítica, que permitiria superar tanto o formalismo - que identifica a matemática escolar com a Matemática acadêmica - quanto o tecnicismo - que exclui a argumentação e a prova do fazer matemático. 


\title{
3.3 O que dizem (e o que não dizem) os PCN acerca da prova
}

No momento em que esta dissertação é escrita, está em processo de consulta pública a Base Nacional Comum Curricular (BNCC), que contém objetivos de aprendizagem que se pretendem em consonância com as Diretrizes Curriculares Nacionais (DCN), publicadas pelo Ministério da Educação e da Cultura (MEC) em 2013. A despeito disso, escolhemos analisar aqui os Parâmetros Curriculares Nacionais (PCN), documento publicado pelo MEC, em 1998, para nortear a educação básica em todo Brasil. ${ }^{16}$ Os PCN não estabelecem uma base curricular comum detalhada, tal como pretende a BNCC, mas dão orientações mais amplas, que procuram definir objetivos gerais da educação básica, organizar as componentes curriculares usuais em cada área de conhecimento, caracterizar tais áreas de conhecimento, estabelecerlhes alguns objetivos gerais e fornecer orientação metodológica aos profissionais da educação.

Nossa escolha pelos PCN, e não por documentos mais recentes, se deve a uma série de motivos. Primeiramente, embora as DCN atualizem concepções sobre a educação, elas não são suficientemente detalhadas para nortear a prática cotidiana dos professores, que ainda têm nos PCN uma referência sólida. Depois, porque o documento que pretende fazer tal detalhamento é a BNCC, ainda em discussão pública (e sob diversas críticas). Assim, entendemos que sua análise seria prematura e talvez inócua, dadas possíveis alterações. Por fim, para entender o quadro atual, temos de olhar o documento que referenciou a educação brasileira das últimas décadas.

Comecemos, então, por analisar a concepção de matemática que se explicita ao longo dos PCN do ensino fundamental II (do $6^{\circ}$ ao $9^{\circ}$ ano):

\begin{abstract}
A Matemática é uma ciência viva, não apenas no cotidiano dos cidadãos, mas também nas universidades e centros de pesquisas, onde se verifica, hoje, uma impressionante produção de novos conhecimentos que, a par de seu valor intrínseco, de natureza lógica, têm sido instrumentos úteis na solução de problemas científicos e tecnológicos da maior importância. [...] O exercício da indução e da dedução em Matemática reveste-se de importância no desenvolvimento da capacidade de resolver problemas, de formular e testar hipóteses, de induzir, de generalizar e de inferir dentro de determinada lógica, o que assegura um papel de relevo ao aprendizado dessa ciência em todos os níveis de ensino (BRASIL, 1998, p. 49).
\end{abstract}

\footnotetext{
${ }^{16}$ Nesta seção, analisamos apenas os PCN de matemática destinados ao ensino fundamental II (do $6^{\circ}$ ao $9^{\circ}$ ano). Furtamo-nos a analisar os PCNEM, destinados ao ensino médio, por entender que a adesão a este documento e seu impacto foram substancialmente menores.
} 
No trecho citado - e em outros - fica claro que a matemática que os PCN recomendam inclui não apenas afirmações sobre objetos matemáticos, mas também atividades que podem levar a estabelecê-las. A matemática é tida como "de natureza lógica", e há clara referência a raciocínios tanto indutivos como dedutivos. Mais adiante, na seção "Conteúdos para o terceiro ciclo", enfatiza-se a importância de trabalhar a justificativa e a argumentação:

No terceiro ciclo, é importante que os alunos sejam estimulados a construir e analisar diferentes processos de resolução de situações-problema e comparálos. Ao desenvolver a capacidade de buscar soluções, favorece-se que o aluno passe a reconhecer a necessidade de construir argumentos plausíveis. A argumentação está fortemente vinculada à capacidade de justificar uma afirmação e, para tanto, é importante produzir alguma explicação, bem como justificá-la. Assim, um argumento será aceito se for pertinente, ou seja, se ele estiver sustentado por conteúdos matemáticos e se for possível responder aos contra-argumentos ou réplica que lhe forem impostos. Uma argumentação não é, contudo, uma demonstração. A argumentação é mais caracterizada por sua pertinência e visa ao plausível, enquanto a demonstração tem por objetivo a prova dentro de um referencial assumido. Assim, a argumentação está mais próxima das práticas discursivas espontâneas e é regida mais pelas leis de coerência da língua materna do que pelas leis da lógica formal que, por sua vez, sustenta a demonstração. Se, por um lado, a prática da argumentação tem como contexto natural o plano das discussões, na qual se podem defender diferentes pontos de vista, por outro, ela também pode ser um caminho que conduz à demonstração (BRASIL, 1998, p. 70).

Nesse excerto, vislumbra-se a concepção de argumentação, prova e demonstração embutida no documento. A demonstração visa provar alguma coisa inequivocamente. A argumentação busca (ou se contenta com) a plausibilidade. Mas ambas são vistas em continuidade, não se postulando uma ruptura entre elas.

Também a seção "Conteúdos para o quarto ciclo" alude a experimentações, justificativas e demonstrações, confirmando a mesma concepção:

Também neste quarto ciclo, os problemas de Geometria vão fazer com que o aluno tenha seus primeiros contatos com a necessidade e as exigências estabelecidas por um raciocínio dedutivo. Isso não significa fazer um estudo absolutamente formal e axiomático da Geometria. Embora os conteúdos geométricos propiciem um campo fértil para a exploração dos raciocínios dedutivos, o desenvolvimento dessa capacidade não deve restringir-se apenas a esses conteúdos. A busca da construção de argumentos plausíveis pelos alunos vem sendo desenvolvida desde os ciclos anteriores em todos os blocos de conteúdo. Assim, esse trabalho terá continuidade no quarto ciclo, uma vez que a prática da argumentação é fundamental para a compreensão das demonstrações. Mesmo que a argumentação e a demonstração empreguem frequentemente os mesmos conectivos lógicos, há exigências formais para uma demonstração em Matemática que podem não estar presentes numa argumentação. $\mathrm{O}$ refinamento das argumentações produzidas 
ocorre gradativamente pela assimilação de princípios da lógica formal, possibilitando as demonstrações. Embora no quarto ciclo se inicie um trabalho com algumas demonstrações, com o objetivo de mostrar sua força e significado, é desejável que não se abandonem as verificações empíricas, pois estas permitem produzir conjecturas e ampliar o grau de compreensão dos conceitos envolvidos (BRASIL, 1998, p. 86-87).

Nesse trecho, também a geometria aparece como o ramo da matemática naturalmente destinado ao desenvolvimento da argumentação e da prova. Nesse aspecto, os PCN retomam a tradição expressa nos currículos mais antigos, que enfatizam o trabalho com a prova e o raciocínio dedutivo na geometria do equivalente ao quarto ciclo do ensino fundamental (PIETROPAOLO, 2005). Por outro lado, o documento explicita que os demais ramos da matemática também se prestam ao desenvolvimento da capacidade de argumentar e provar.

No geral, o documento recomenda que os conteúdos matemáticos sejam trabalhados de modo organicamente entrelaçado à lógica, com exigência formal crescente ao longo do ensino fundamental: o aluno deve ir das argumentações calcadas puramente na coerência das leis da língua materna às demonstrações simples e semiformais, com maior clareza de alguns princípios norteadores da lógica formal. Assim, quanto às concepções que expressam, os PCN estão em concordância com um trabalho robusto com argumentação e prova na matemática escolar, desde (pelo menos) o ensino fundamental II.

Mas será que as concepções expressas se articulam com as demais recomendações contidas nesse documento? Será que os PCN detalham como pode ser desenvolvido um trabalho com argumentação e prova no ensino fundamental II? Será que problematizam o assunto? Será que discutem as dificuldades desse tipo de trabalho ou como avaliar o desenvolvimento dos alunos com relação a ele? Parece-nos claro que, se o professor compartilha das concepções expressas no documento e se já desenvolve um trabalho significativo com argumentação e prova, então o que examinamos até agora é suficiente para encorajá-lo a continuar nessa direção. Mas queremos verificar se essas orientações curriculares subsidiam a operacionalização das concepções que expressam de modo a favorecer o trabalho com argumentação e prova na matemática escolar, ainda que o professor, de partida, não saiba como fazê-lo nem vislumbre o valor desse tipo de trabalho.

De fato, parece-nos que os PCN não dão conta de responder a tais questões, carecendo de detalhamento no tocante a um trabalho pedagógico intencional para o desenvolvimento da argumentação e da prova em matemática. Além da seção "Conteúdos", as orientações 
curriculares específicas para cada ciclo estão organizadas nas seções “Objetivos", "Conceitos e procedimentos" e "Avaliação". Em nenhuma delas há menção explícita às possíveis articulações com argumentação, prova ou demonstração ou ao desenvolvimento desses tópicos. Talvez justamente porque aí a argumentação e a prova sejam vistas como aspectos naturalmente inerentes à matemática, acaba-se por desconsiderar a necessidade de estabelecer intencionalmente objetivos específicos a respeito, procedimentos para alcançá-los ou critérios para avaliar se estão sendo desenvolvidos adequadamente.

Pietropaolo (2005), que participou da elaboração dos PCN, confirma nossa leitura de que eles não oferecem orientações suficientes relativas a nosso tema de interesse:

Havia um consenso inicial entre os membros da equipe de elaboração dos PCN no que concerne às concepções gerais do documento e em particular quanto à adoção da resolução de problemas como um princípio norteador do fazer matemática em sala de aula. Ao longo do processo de construção dos PCN ocorreram, evidentemente, muitas discussões entre membros da equipe e representantes da comunidade de Educação Matemática, a respeito de diversas posições a ser adotadas, seja em relação aos objetivos, à seleção e organização de conteúdos. No entanto, foram pouco profundos os debates sobre argumentações e provas e sobre suas potencialidades pedagógicas. Mesmo assim, no item "Orientações didáticas", encontram-se algumas reflexões sobre esse tema e apenas no que se refere ao desenvolvimento do pensamento geométrico (p. 27, grifo nosso).

O autor conjectura ainda que uma possível causa desse "vazio" relativo a argumentação e prova nos PCN seria a pouca pesquisa dedicada ao tema à época de sua elaboração. De todo modo, o que concluímos nesta seção é que a análise dos PCN reforça nossa percepção de que argumentação e prova têm sido um tema relegado a segundo plano no contexto educacional brasileiro das últimas décadas e, num ciclo vicioso, que essa omissão acaba perpetuando sua falta. 
Parte 2

INVESTIGAÇÃO DE CAMPO 


\section{A investigação de campo}

Nossa investigação teórica lançou luz sobre muitas das questões levantadas a respeito da prova na matemática escolar, mas duas delas só podem ser discutidas a partir da interlocução com professores da educação básica (a segunda muito mais ampla):

- Como os professores de matemática entendem a relação entre matemática e raciocínio lógico? Essa relação envolve, em alguma medida, as noções de argumentação e prova?

- O que pode dificultar que os professores de matemática da educação básica implementem um trabalho significativo com argumentação e prova em sala de aula?

Assim, lançamo-nos a uma investigação de campo qualitativa observando um pequeno grupo de quatro professoras de matemática da educação básica que, entre março de 2013 e março de 2015, participaram, no IME-USP, do projeto Ensino de Matemática na Escola Elementar, do programa Observatório da Educação (OBEDUC), financiado pela Coordenação de Aperfeiçoamento de Pessoal de Nível Superior (CAPES).

\subsection{O projeto Ensino de Matemática na Escola Elementar}

A ideia central do projeto Ensino de Matemática na Escola Elementar foi concorrer para a melhoria do ensino de matemática na educação básica por meio de um vínculo de cooperação entre universidade e escolas. De um lado, participaram alunos de graduação e de pós-graduação e docentes do IME-USP e, de outro, professoras de matemática de escolas públicas da cidade de São Paulo (nossos sujeitos de pesquisa).

Boa parte das ações do projeto foi desenvolvida na disciplina Projetos de Estágio (MAT-1500), da grade regular do curso de Licenciatura do IME-USP. Os alunos de graduação eram os licenciandos matriculados nessa disciplina em 2013 e em 2014, as professoras da educação básica (todas bolsistas da CAPES) se matricularam na disciplina de extensão do IME-USP Aprendendo com Projetos, e os alunos de pós-graduação eram mestrandos do MPEM. A coordenação do projeto era da prof $^{\mathrm{a}} \mathrm{dr}^{\mathrm{a}}$ Cláudia Cueva Candido, orientadora desta dissertação, e, na ocasião, docente responsável por turmas da disciplina MAT-1500. 
Quanto às funções de cada um no projeto, vale destacar que:

- os licenciandos, divididos em equipes, deviam elaborar planos de ensino a partir das demandas das professoras da educação básica. Esses planos de ensino eram discutidos e aperfeiçoados por toda a equipe e depois aplicados nas escolas pelos licenciandos, com supervisão das professoras;

- os mestrandos contribuíram com os planos de ensino propondo a leitura de textos pertinentes, conduzindo sua discussão e ministrando oficinas; ao mesmo tempo, eles podiam colher dados para sua própria pesquisa;

- as professoras da educação básica levaram suas demandas e dificuldades, criticaram e contribuíram ativamente com os planos de ensino em elaboração, cederam parte de suas aulas para a aplicação dos mesmos e contribuíram com a pesquisa dos mestrandos.

Assim, o foco do projeto Ensino de Matemática na Escola Elementar era muito mais amplo que a pesquisa de qualquer um dos mestrandos envolvidos. Os diversos objetivos traçados - relativos à formação dos licenciandos, à formação continuada das professoras, às diversas demandas dos mestrandos etc. - exigiram grande esforço de coordenação. Também nos exigiu bastante, no sentido de manter a atenção em nosso tema de interesse, frente à miríade de questões e à variedade de tarefas que se colocaram ao longo do projeto.

Se não foi o ideal para aprofundar nosso tema de interesse, por outro lado, esse contexto permitiu construir uma visão ampla - como um mosaico - do modo como o tema da prova e da validação do conhecimento matemático permeia o discurso e a prática das professoras de matemática da educação básica que participaram do projeto.

Na próxima seção, fazemos uma descrição mais minuciosa de nossa investigação no referido projeto.

\subsection{Metodologia de pesquisa}

Em primeiro lugar, em função de nosso trabalho como formadora, queríamos de focalizar professores como sujeitos de pesquisa, e a oportunidade que se apresentou para isso, no âmbito do projeto Ensino de Matemática na Escola Elementar - OBEDUC, envolvia um pequeno grupo, de apenas quatro professoras. De um lado, isso inviabilizava uma pesquisa 
quantitativa, e, de outro, as questões de pesquisa e todo o contexto estabelecida mostravam-se mais adequados a uma investigação qualitativa. Segundo Lüdke e André (1986, p. 11), "a pesquisa qualitativa supõe o contato direto e prolongado do pesquisador com o ambiente e a situação que está sendo investigada, via de regra através do trabalho intensivo de campo". Essa descrição se aplica exemplarmente na situação de pesquisa em que nos vimos envolvidos. Além disso, nossa preocupação essencial era muito mais com o processo que com o produto, importando captar a visão dos sujeitos de pesquisa sobre o tema da argumentação e da prova.

Das estratégias de pesquisa qualitativa, escolhemos o estudo de caso, por diversos motivos. O primeiro foi a própria natureza das perguntas que nos colocamos, que podem ser (aproximadamente) parafraseadas em perguntas do tipo “como?" e "por quê?": Como os professores veem a relação entre raciocínio lógico e matemática? Por que não trabalham sistematicamente com a prova matemática em sala de aula? Yin (2001, p. 25) explica:

[...] questões do tipo "como" e "por que" são mais explanatórias, e é provável que levem ao uso de estudos de casos, pesquisas históricas e experimentos como estratégias de pesquisa escolhidas. Isso se deve ao fato de que tais questões lidam com ligações operacionais que necessitam ser traçadas ao longo do tempo, em vez de ser encaradas como meras repetições ou incidências.

O autor salienta que o estudo de caso é conveniente quando se deseja pesquisar um "conjunto contemporâneo de acontecimentos sobre os quais o pesquisador tem pouco ou nenhum controle" (YIN, 2001, p. 28). Mais uma vez, entendemos que era esse o nosso caso.

Da fase inicial à final, nossa atuação na pesquisa se deslocou, nos termos de Junker (1971 ${ }^{17}$ apud LÜDKE; ANDRÉ, 1986), de "participante como observador" a "observador como participante". Em outras palavras, inicialmente, não compartilhamos completamente nossos objetivos de pesquisa com o grupo de professoras, para não induzir comportamentos ou discursos. Porém, ao longo do projeto, esses objetivos foram sendo revelados, até o momento em que pudemos discuti-los abertamente com as professoras.

\footnotetext{
${ }^{17}$ JUNKER, B. H. A importância do trabalho de campo. Rio de Janeiro: Lidador, 1971.
} 


\subsubsection{Os sujeitos da pesquisa}

As professoras participantes do projeto têm diferentes tempo de atuação, formação, motivações, interesses, estilo e realidade profissional, como se vê na breve descrição do perfil profissional de cada uma. Esses perfis se baseiam em informações fornecidas pelas próprias professoras, sobretudo num questionário (comentado mais adiante), acrescidas de algumas poucas inferências que fizemos no contato prolongado com as elas.

\section{Professora A}

Leciona matemática desde 2010. Formou-se no próprio IME-USP e, desde então, tem frequentado esporadicamente o CAEM, para participar de atividades de formação continuada. Também cursou Especialização em Matemática pelo projeto RedeFor, na UNICAMP, quando cursava graduação em Pedagogia, na Faculdade de Educação (FEUSP).

Conta que sempre teve o desejo de lecionar - em qualquer área -, por gostar de aprender e de ensinar. Escolheu a matemática porque ela sempre teve facilidade com a disciplina. Se diz satisfeita profissionalmente, sobretudo "quando o aluno aprende".

Como possíveis contribuições da matemática à formação dos alunos, ela destaca o “desenvolvimento do raciocínio (lógico, inclusive)" e o "uso no cotidiano".

À época do projeto, a professora A lecionava no ensino fundamental II na rede pública estadual e na rede pública municipal (com cargo efetivo em ambas). Demonstra muito interesse pelo desenvolvimento de seus alunos, percepção corroborada pelo fato de ela haver estabelecido um acordo com a equipe gestora de uma das escolas em que trabalha para acompanhar seus alunos de $6^{\circ}$ ano até o $9^{\circ}$ ano. Segundo ela, a experiência de lecionar no $6^{\circ}$ ano foi tão marcante que a motivou a cursar Pedagogia, para compreender melhor o desenvolvimento das crianças.

Nas discussões coletivas, a participação da professora A foi bastante tímida aparentemente, mais por questão de personalidade que de engajamento, uma vez que ela foi bastante assídua e disponível durante todo o projeto, além de ter elaborado projetos de ensino próprios para aplicar em suas turmas. 


\section{Professora B}

Leciona matemática desde 1979. Formou-se bacharel e licenciou-se em Matemática pela Pontifícia Universidade Católica de São Paulo (PUC-SP). À época do projeto, cursava pós-graduação em Psicopedagogia Educacional, em instituição não informada. Além disso, já participou de diversas atividades de formação continuada, inclusive no IME-USP, em projetos ligados à Olimpíada Brasileira de Matemática das Escolas Públicas (OBMEP). Apesar disso, ela afirmou no questionário só participar de formação continuada quando a escola a convoca.

No questionário, responde que optou por ser professora "justamente por falta de opção”. Por outro lado, se declara satisfeita profissionalmente e descreve sua satisfação do seguinte modo: “A maior satisfação é quando o(a) aluno(a) diz 'odeio matemática', e este mesmo aluno consegue andar com as próprias pernas. Cria autonomia."

Quanto à maior contribuição que a matemática pode dar à formação dos alunos, escreve: "A maior contribuição que o aprendizado da matemática pode dar é a capacidade de raciocinar, usar a lógica. Para fazer uma leitura de um texto, é preciso raciocinar. Para tomar qualquer decisão, é preciso raciocinar, usar a lógica. A interpretação é raciocínio. Logo, tudo precisa de matemática, que dá os caminhos da resolução e o pensar."

À época do projeto, a professora B lecionava no $8^{\circ}$ e no $9^{\circ}$ ano do ensino fundamental e no ensino médio, numa única escola da rede publica estadual de São Paulo, onde tem cargo efetivo.

Um padrão recorrente que observamos durante a interação com essa professora é que ela valoriza bastante os alunos que têm bom desempenho, sobretudo na OBMEP (atividade que parece mobilizar bastante a escola em que trabalha). Por outro lado, ela se mostra impaciência quando cita alunos que apresentam dificuldades, atribuindo-as geralmente a características cognitivas inerentes aos alunos ou à preguiça de estudar.

\section{Professora C}

Leciona matemática desde 1973. Licenciou-se em Matemática pela Universidade de Guarulhos e chegou a iniciar mestrado em Matemática no IME-USP, mas não concluiu. Frequentemente procura atividades de formação continuada, por seu próprio interesse. 
A professora $\mathrm{C}$ diz não ter optado pela carreira de professora, mas ter cursado Matemática "por curiosidade". Desde o $1^{\circ}$ ano de graduação, o trabalho docente acabou sendo uma decorrência não planejada - embora previsível - dessa curiosidade.

Essa professora foi muito participativa em todas as discussões, tem muitas ideias e expressa interesses múltiplos. Essa multiplicidade tem vazão quando ela pode atuar em disciplinas eletivas - em que tem mais liberdade para propor temas de estudo variados aos alunos -, e ela a menciona como fonte de satisfação profissional.

A possibilidade de ministrar disciplinas eletivas se deve ao fato de a professora lecionar no ensino médio de uma escola de tempo integral da rede estadual paulista, em que têm lugar diversas atividades pouco usuais em outras unidades da rede. Apesar disso, a professora $\mathrm{C}$ se queixa bastante de seu contexto escolar, sobretudo pela falta de interlocução e de identificação com seus pares.

A respeito da maior contribuição que a matemática pode dar à formação dos alunos, ela problematiza e se questiona: "Esta é uma questão com a qual sempre me debato. Pensando no indivíduo de forma integral, muitas podem ser as contribuições, tais como melhorar a autoestima. Não penso na matemática como um instrumento para um único fim, como pensam de modo geral, que serve apenas para desenvolver o raciocínio lógico. Ora, isso a filosofia também faz. Que sentido tem o currículo globalizado para indivíduos de diferentes sociedades e para os analfabetos?"

Por ora, notamos apenas que a preocupação da professora C com a autoestima dos alunos foi recorrente durante o projeto.

\section{Professora D}

Leciona matemática desde 1997. Sua formação não foi em Matemática, mas em Ciências com habilitação em Matemática, na Universidade Santana, na cidade de São Paulo.

Em 2013, lecionava matemática no ensino médio na rede pública estadual de São Paulo, na capital. Em 2014, aumentou consideravelmente seu número de aulas e passou a lecionar em todos os anos do fundamental II e do ensino médio, ainda na rede estadual, em duas escolas. 
No questionário, ela se disse muito insatisfeita profissionalmente, por não conseguir mostrar aos alunos do ensino médio que o conhecimento pode promover mudanças na realidade social e trazer satisfação pessoal. A importância que dá ao conhecimento como motriz de mudanças sociais também aparece quando ela explica por que escolheu ser professora: "Para poder mudar e passar informação às pessoas. Pois acredito que, através do conhecimento, podemos mudar o meio em que vivemos e posteriormente mudar uma sociedade, fazendo com que todos possam construir e fazer melhores sua vida e a dos que estão em torno."

Segundo seu relato, os alunos da escola em que leciona a professora D são bastante desfavorecidos social e economicamente. Parece-nos que essas carências concorrem para o que a professora sempre tenha expressado preocupação em estabelecer vínculos de afeto com seus alunos e um acompanhamento pormenorizado de suas atividades - para que se sintam acolhidos e respondam com receptividade. No contexto dessa escola, isso parece lhe valer o reconhecimento da equipe gestora e dos alunos.

Para ela, a maior contribuição da matemática escolar à formação dos alunos é: "Uma ampliação de novas possibilidades e que é preciso pensar, estabelecer comparações e análise de maneira geral para solucionar situações problemas."

Relata ter participado, por interesse próprio, de várias atividades de formação contínua.

Apesar da heterogeneidade desse pequeno grupo, alguns aspectos aproximam as professoras: a atuação na rede pública de ensino na cidade de São Paulo (estadual ou municipal) e algum grau de engajamento em seu próprio aperfeiçoamento profissional. Além disso, o próprio projeto as aproximou, pela oportunidade de diálogo e trocas.

\subsubsection{Instrumentos de coleta de evidências}

Colheram-se evidências por meio de vários os instrumentos, o que, a despeito de tornar a análise mais complexa, permitiu que ela fosse mais acurada. De fato, o recurso a diversas fontes é um dos princípios elencados para a boa condução de um estudo de caso (YIN, 2001, p. 119). Sobre esse princípio, o autor destaca: 
O uso de várias fontes de evidências nos estudos de caso permite que o pesquisador dedique-se a uma ampla diversidade de questões históricas e comportamentais e de atitudes. A vantagem mais importante, no entanto, é o desenvolvimento de linhas convergentes de investigação [...]. Assim, qualquer descoberta ou conclusão em um estudo de caso será muito mais convincente e acurada se se basear em várias fontes distintas de informação, obedecendo a um estilo corroborativo de pesquisa (p. 121, grifo do original).

A seguir, descrevemos esses instrumentos de coleta de evidências a partir da forma de interação que os originou.

\section{Encontros do MAT-1500}

Mais uma vez, a disciplina de estágio MAT-1500 serviu de apoio à investigação. Os encontros nessa disciplina foram quinzenais, ao longo dos períodos letivos de 2013 e de 2014, e envolveram toda a equipe ligada ao projeto Ensino de Matemática na Escola ElementarOBEDUC.

Embora os assuntos discutidos nos encontros não se subordinassem a nossa pesquisa, o tema da argumentação e da prova apareceu diversas vezes, implícita ou explicitamente (embora menos). Além disso, observaram-se muitas outras evidências relevantes, como o posicionamento e o padrão de interação das professoras com os licenciandos na elaboração dos planos de ensino, seu repertório matemático, sua percepção das escolas em que lecionam etc. Assim, um de nossos instrumentos de coleta de evidências foram nossos registros manuscritos de observação desses encontros.

\section{Sessões de análise de prática}

Durante todo o ano de 2014, a professora Cláudia Cueva, coordenadora do projeto Ensino de Matemática na Escola Elementar-OBEDUC, propôs e conduziu quinzenalmente sessões de análise de prática, contando com a presença do grupo de professoras e de duas alunas de mestrado (inclusive eu). Inspiradas nas propostas de Perrenoud (2002), essas sessões tinham a finalidade de levar as professoras a refletirem sobre suas práticas de sala de aula, sobre tópicos de matemática e sobre toda sorte de questões relativas a sua atuação docente. Em função do pequeno número de participantes e da participação ativa das duas 
mestrandas nas discussões, nossos temas de pesquisa tiveram mais destaque nessas sessões que nos encontros do MAT-1500. Assim, nossas anotações dessas sessões - elaboradas durante ou logo após as mesmas - constituem um importante registro de observação para nossa pesquisa.

\section{Aplicação de questionários}

Tivemos também duas reuniões extraordinárias com as professoras, para tratar especificamente desta pesquisa. No primeiro, em agosto de 2013, as professoras responderam individualmente ao questionário escrito que elaboramos (Apêndice). Mais tarde, no mesmo dia, discutimos coletivamente as impressões das professoras sobre o questionário.

Um problema que achamos relevante relatar diz respeito ao descompasso entre o momento de elaboração e aplicação do questionário e o momento de maior aprofundamento teórico e metodológico em nossa pesquisa. Consideramos que, tendo sido aplicado antes dessa fase de aprofundamento, acabou sendo subaproveitado. Ainda assim, foi um instrumento importante, por diversas razões. A primeira delas é que motivou o grupo a ponto de a reunião que se seguiu a sua aplicação ter sido espontânea, porque as professoras começaram a discutir e trocar impressões, opiniões e dificuldades que sentiram ao respondê-lo.

O questionário permitiu traçar alguns marcos importantes da trajetória profissional dessas professoras, compreendendo melhor seu contexto e sua atuação. Com isso, redigimos um breve perfil profissional de cada uma, usando o mínimo possível de inferências próprias. O objetivo desses perfis era fornecer um panorama que apoiasse a análise das evidências:

Os estudos de caso enfatizam a "interpretação do contexto". Um princípio básico desse tipo de estudo é que, para uma apreensão mais completa do objeto, é preciso levar em conta o contexto em que ele se situa. Assim, para compreender melhor a manifestação geral de um problema, as ações, as percepções, os comportamentos e as interações das pessoas devem ser relacionadas à situação específica em que ocorrem ou à problemática determinada a que estão ligadas (LÜDKE; ANDRÉ, 1986, p. 18-19, grifo do original).

Por fim, ao propor questões específicas, o questionário ensejou alguma compreensão sobre o repertório matemático das professoras e, principalmente, indícios de sua familiaridade com provas e demonstrações. 


\section{Entrevistas}

As outras reuniões extraordinárias ocorreram em fevereiro de 2015. Marcamos entrevistas individuais (registradas em áudio) com cada professora. O objetivo dessas entrevistas era não só colher evidências complementares para a pesquisa, mas também validar algumas de nossas interpretações das demais evidências coletadas junto às professoras. Infelizmente, apenas três das quatro participantes compareceram a essas entrevistas. (A professora $\mathrm{D}$ declinou por razões pessoais.)

As entrevistas foram semiestruturadas, e a pauta que as conduziu cobriu aspectos específicos que gostaríamos de discutir com cada professora. Conforme o andamento da conversa, alteramos o encadeamento das perguntas e incluímos ou suprimimos outras a fim de perscrutar nossas questões de pesquisa da melhor forma. O clima de colaboração construído ao longo do projeto permitiu que as entrevistas fluíssem como um diálogo aberto e autêntico.

Segundo Yin (2001, p. 113), essa é a chamada entrevista focal, relativamente curta, espontânea e em tom de conversa informal, ainda que, na realidade, o pesquisador se esteja baseando num conjunto de perguntas previamente formuladas.

Optamos por não transcrever os registros em áudio completos das três entrevistas realizadas (com cerca de 90 minutos cada), por entender que era desnecessário aos propósitos desta dissertação. Assim, foram transcritos apenas os trechos analisados diretamente.

\section{Documentos complementares}

Além do questionário escrito, dos registros de observação das reuniões e das entrevistas gravadas em áudio, pedimos, no fim de 2014, que as professoras nos cedessem cópias de material/atividades que aplicaram em suas aulas e que consideravam representativos do seu trabalho. Com isso, esperávamos compreender melhor alguns aspectos da pesquisa. Por exemplo, nos questionários, todas afirmaram demandar frequentemente ou sempre que seus alunos justificassem procedimentos e decisões matemáticas. Mas o que exatamente elas entendem por justificativa? Em certa medida, a análise desse material ajudou a esclarecer essa e outras questões similares. 
A professora A nos cedeu o caderno de uma aluna e um trabalho sobre equações realizado por outra, ambas do $8^{\circ}$ ano do fundamental. O conteúdo do caderno, referente ao $4^{\circ}$ bimestre, era sobre técnicas de cálculo algébrico, resolução de equações e, com menos destaque, equacionamento de problemas.

A professora B nos cedeu três materiais do $9^{\circ}$ ano: duas listas de questões e cópia de um trecho de caderno. Uma das listas continha 13 questões de múltipla escolha extraídas das avaliações do Sistema de Avaliação de Rendimento Escolar do Estado de São Paulo (SARESP), divididas nos níveis "básico" (uma questão), "adequado" (quatro questões) e "avançado" (oito). Na mesma lista, havia cinco questões abertas, também do SARESP. A segunda lista continha 16 questões sobre relações métricas no triângulo retângulo. Já os registros no caderno do aluno versavam sobre o teorema de Pitágoras.

A professora $\mathrm{C}$ cedeu material do $1^{\mathrm{o}}$ ano do ensino médio. Algumas produções de alunos, como gráficos de funções exponenciais construídos em papel quadriculado a partir de tabelas e gráficos estatísticos de colunas, onde eles descrevem seu rendimento ao longo do ano, em todas as disciplinas. Além disso, ela também trouxe um dominó de números racionais, contendo representações numéricas e pictóricas, e uma lista com seis questões preparatórias para o " $4^{\circ}$ provão de Matemática", atividade avaliativa que tem lugar na escola onde leciona.

A professora D tampouco nos cedeu material.

\subsubsection{O caso em estudo}

Segundo Yin (2001), a definição do caso a ser estudado depende não apenas das questões de pesquisa e de algumas proposições assumidas de partida, mas da definição de unidades de análise. O que será analisado? Dizer que analisaremos o grupo de professoras seria demasiado vago e poderia dar margem à interpretação de que há quatro estudos de caso, se tomarmos cada pessoa como unidade de análise, e isso seria incorreto.

Essa simplificação também permitiria supor que estamos interessados em analisar o trabalho das professoras em sala de aula com argumentação e prova, o que também seria incorreto, posto que não as observamos lecionando. Optamos por trabalhar com os conhecimentos, as concepções e as crenças que elas próprias exprimiram acerca do tema, 
espontaneamente ou respondendo a perguntas nossas, a partir de suas falas ou ações. Este é o caso em análise: o conjunto de conhecimentos, crenças ou concepções expressas pelas professoras com relação ao tema do raciocínio lógico e da prova matemática.

Sendo esses termos cruciais para a explicitação do caso em tela, detemo-nos aqui para explicar o sentido que damos a conhecimento, concepção e crença.

Primeiramente, observamos que concepção é um termo bastante debatido no campo da Educação, especialmente da Educação Matemática e do Ensino de Ciências (GARNICA, 2008). Apesar disso, não parece haver para ele um significado consensual, o que ilustramos com os seguintes dois pontos de vista:

Vamos considerar como "concepções" os "algos" (crenças, percepções, juízos, experiências prévias etc.) a partir dos quais nos julgamos aptos a agir. Concepções são, portanto, suportes para a ação. Mantendo-se relativamente estáveis, as concepções criam em nós alguns hábitos, algumas formas de intervenção que julgamos seguras. Essa vinculação entre concepção e ação não é nova nem pode ser creditada a uma única teoria. Vários teóricos trataram do tema da ação, das práticas humanas e de seus fundamentos. Segundo Romulo Campos Lins (1999), a associação entre produção de conhecimento e ação tem uma longa tradição, que passa, por exemplo, por Charles Sanders Peirce, Gaston Bachelard e Gerard Vergnaud (GARNICA, 2008, p. 499).

O interesse pelo estudo das concepções dos professores, tal como, aliás, pelo estudo das concepções de outros profissionais e de outros grupos humanos, baseia-se no pressuposto de que existe um substracto conceptual que joga um papel determinante no pensamento e na acção. Este substracto é de uma natureza diferente dos conceitos específicos - não diz respeito a objectos ou acções bem determinadas, mas antes constitui uma forma de os organizar, de ver o mundo, de pensar. Não se reduz aos aspectos mais imediatamente observáveis do comportamento e não se revela com facilidade - nem aos outros nem a nós mesmos.

As concepções têm uma natureza essencialmente cognitiva. Actuam como uma espécie de filtro. Por um lado, são indispensáveis, pois estruturam o sentido que damos às coisas. Por outro lado, actuam como elemento bloqueador em relação a novas realidades ou a certos problemas, limitando as nossas possibilidades de actuação e compreensão.

As concepções formam-se num processo simultaneamente individual (como resultado da elaboração sobre a nossa experiência) e social (como resultado do confronto das nossas elaborações com as dos outros). Assim, as nossas concepções sobre a Matemática são influenciadas pelas experiências que nos habituámos a reconhecer como tal e também pelas representações sociais dominantes (PONTE, 1992, p. 1).

Os autores citados relacionam concepção e ação - Garnica mais enfaticamente que Ponte. Para ambos, as concepções têm grande influência na ação, uma vez que a suportam ou 
funcionam como filtros por meio dos quais atribuímos sentido à realidade. Ponte, entretanto, caracteriza as concepções como sendo de natureza cognitiva, enquanto Garnica inclui entre elas as crenças, as experiências e os juízos - que não podem ser reduzidos à dimensão cognitiva.

Nossa opção por distinguir concepção e crença nos parece em consonância com o ponto de vista de Ponte (1992). Exatamente em função da natureza cognitiva que imputamos às concepções, é necessário falar também em crenças. Nesse sentido, a análise das crenças é que permitirá sublinhar os aspectos mais subjetivos do ponto de vista das professoras sobre nosso tema de investigação.

Por outro lado, sendo as concepções formas geralmente implícitas de organizar e atribuir sentido à realidade, também é preciso distingui-las dos conhecimentos, que seriam saberes objetivos, mais específicos e conscientes. Assim, a análise dos conhecimentos das professoras relativamente à matemática, à lógica, à prova e à argumentação nos parece relevante para esta investigação.

$\mathrm{O}$ excerto a seguir ilustra muito didaticamente a distinção entre conhecimento e crença:

\begin{abstract}
Mesmo que as fronteiras entre conhecimento e crença estejam pouco claras, R. P. Abelson (1979) apontou algumas diferenças que ajudam a delimitar ambos os conceitos, atendendo aos seguintes aspectos: o caráter mais objetivo do conhecimento e mais subjetivo das crenças. Estas podem manterse com diferentes graus de convicção, e os conhecimentos são consensuais para um determinado grupo humano. No entanto, as crenças nem sempre são fruto de um consenso, já os conhecimentos respondem a alguns critérios de verdade que não satisfarão as crenças: por exemplo, enquanto o teorema de Pitágoras é um conhecimento objetivo, pensar que o teorema de Pitágoras só é demonstrado de uma forma é uma crença, isto é, um conhecimento subjetivo, certamente arraigado no fato de não conhecer mais que uma demonstração (VILA; CALLEJO, 2007, p. 46).
\end{abstract}

Assim, com relação a nosso tema, podemos dizer, por exemplo, que alguma das professoras tem ou não determinado conhecimento específico para provar determinado resultado. Mas diremos, por exemplo, que uma possível crença das professoras é de que a atividade de provar não é pertinente no contexto escolar. Podemos ainda dizer que, na concepção de uma professora, uma prova só vale se estiver escrita em linguagem algébrica.

Embora as distinções feitas aqui sejam fundamentais do ponto de vista da estruturação teórica do trabalho e tenham sido um suporte importante para o desenvolvimento da 
investigação de campo, no decorrer da análise das evidências, o foco se desloca para a relação dinâmica entre essas noções. Ou seja, tomamos essas noções de forma integrada para responder da melhor forma possível às nossas questões de pesquisa. Dessa forma, não nos preocupamos demasiadamente em categorizar os diversos tipos de saber que sublinhamos na análise.

Por fim, o capítulo a seguir, que trata da análise das evidências, está organizado a partir de temas que evidenciam conhecimentos, crenças ou concepções das professoras do grupo relativamente ao raciocínio lógico e à prova matemática. 


\title{
5 Análise das evidências coletadas
}

\author{
Nas palavras de Yin (2001, p. 131):
}

\begin{abstract}
Analisar as evidências de um estudo de caso é uma atividade particularmente difícil, pois as estratégias e as técnicas não foram bem definidas no passado. Ainda assim, cada pesquisador deve começar seu trabalho com uma estratégia analítica geral - estabelecendo prioridades do que deve ser analisado e por quê.
\end{abstract}

Nessa perspectiva, reexaminamos as questões de pesquisa e nossas proposições - isto é, as hipóteses de que partimos e que deram o enquadre de toda a investigação. Nossa motivação inicial foi a percepção de uma aparente contradição. Se, por um lado, os professores costumam valorizar a relação entre o estudo da matemática e desenvolvimento do raciocínio lógico, por outro, não parecem valorizar da mesma forma atividades relativas à argumentação ou à prova matemática, que é uma forma privilegiada de trabalhar esse tipo de raciocínio. Porém, concluímos que essa contradição era apenas aparente, porque há diferentes concepções de raciocínio lógico entre os professores, e essa expressão nem sempre é usada com o mesmo significado que lhe atribuímos.

De todo modo, essa aparente contradição nos levou a querer compreender o que as professoras participantes da pesquisa entendem por raciocínio lógico e se de alguma maneira, como nós, elas o relacionam com provas e demonstrações. Ou seja, o que nos interessa nesta seção são os conhecimentos, as crenças e as concepções das professoras acerca do que é raciocínio lógico. Esses pontos foram observados durante todo o projeto, mas emergiram mais claramente nos questionários e nas entrevistas.

Também pretendemos, com o estudo de caso, investigar o que pode impedir que os professores trabalhem com a prova matemática em sala de aula.

Organizamos a análise das evidências em três seções, respectivamente relativas às seguintes questões:

- como as professoras participantes da pesquisa entendem e usam a expressão raciocínio lógico?

- essas professoras estabelecem relação entre raciocínio lógico e prova?

- o que dificulta que essas professoras trabalhem com a prova matemática em sala de aula? 
Assim, em cada uma das seções a seguir, procuramos, articulando as diversas evidências coletadas, elos causais para orientar nossa análise d essas questões.

\subsection{Conhecimentos, concepções e crenças associadas ao raciocínio lógico}

O primeiro fato que nos parece digno de nota em nosso estudo de caso é que a expressão raciocínio lógico apareceu nas respostas de três das quatro professoras à pergunta:

- Qual você acredita que seja a maior contribuição que o aprendizado da matemática dá à formação geral do aluno?

professora A: Desenvolvimento do raciocínio (lógico, inclusive); uso no cotidiano.

professora B: A maior contribuição que o aprendizado da matemática pode dar é a capacidade de raciocinar, usar a lógica. Para ler um texto, é preciso raciocinar. Para tomar qualquer decisão, é preciso raciocinar, usar a lógica. Interpretação é raciocínio. Logo, tudo precisa de matemática, que dá os caminhos da resolução e o pensar.

professora C: Essa é uma questão com a qual sempre me debato. Pensando no indivíduo integral, muitas podem ser as contribuições, tais como melhorar a autoestima. Não penso na matemática como um instrumento para um único fim, como pensam de modo geral, que serve apenas para desenvolver o raciocínio lógico. Ora, isso a filosofia também faz. Que sentido tem o currículo globalizado para indivíduos de diferentes sociedades e para os analfabetos?

professora D: Uma ampliação de novas possibilidades e que é preciso pensar, estabelecer comparações e análise de maneira geral para solucionar situações problemas."

A resposta da professora $\mathrm{C}$ indica que ela percebe que seus pares costumam ver matemática como um instrumento para o desenvolvimento do raciocínio lógico. Ela não se opõe a essa "função" da matemática, mas procura ultrapassá-la, por reconhecer que o raciocínio lógico não é uma prerrogativa da matemática, mas algo que se desenvolve também por outras vias (ideia que reafirmou na entrevista). Ou seja, ela concorda que a aprendizagem da matemática concorre para o desenvolvimento do raciocínio lógico, mas não reconhece aí uma especificidade. Já a resposta da professora B sugere que, de certa forma, ela identifica quase completamente o raciocínio lógico e a matemática. Parte da premissa de que tudo 
demanda raciocínio (lógico) e conclui que tudo precisa de matemática. Nesse sentido, temos aí dois exemplos de posicionamentos bem distintos do grau de relação entre matemática e raciocínio lógico.

$\mathrm{Na}$ resposta da professora $\mathrm{B}$, o termo raciocinar, sem advérbios, é seguido de "usar a lógica”, como se a segunda expressão o explicasse. Isso sugere que, para ela, todo raciocínio é lógico. Nesse sentido, a resposta da professora A é completamente diferente, uma vez que ela salienta a adjetivação lógico, indicando que entende que a contribuição da matemática é desenvolver diferentes tipos de raciocínio.

Essa nossa interpretação foi confirmada e aprofundada nas entrevistas, quando retomamos as respostas aos questionários e perguntamos explicitamente: "o que você entende por 'raciocínio lógico'?”. A seguir, transcrevemos os trechos mais relevantes das respostas.

\section{Professora A}

pesquisadora (P): Uma das primeiras coisas que eu queria discutir com você tem a ver com a relação entre matemática e raciocínio lógico. No questionário que você respondeu no começo do projeto (você se lembra?), havia uma pergunta sobre a principal contribuição que a matemática pode dar à formação geral dos alunos. Você escreveu a resposta de um jeito que me chamou a atenção: "raciocínio" e, entre parênteses, "lógico, inclusive". O que você entende por raciocínio? E por que "lógico, inclusive"?

A: Então, hoje foi a primeira aula que eu dei no ensino médio... Disse a eles que eu ia dar uma prova, que essa prova ia ser individual, e que ia ser individual mesmo... porque eu pensei que as questões seriam bem diferentes para eles. E que eu ia mais valorizar o raciocínio. Falei assim: "Eu não estou interessada na resposta certa, mas no raciocínio, no que é que você vai fazer para chegar àquela resposta. E, inclusive, às vezes, para você responder àquele problema, àquela questão, talvez você nem use exatamente o conteúdo que eu ensinei; talvez você consiga resolver de outra forma, e eu vou achar isso ótimo. É claro que, se você resolver usando o conteúdo que eu ensinei, também vou achar bom”. Mas acho que, de alguma forma, quando eu ensino matemática, ensino também uma forma de pensar... Acho que é a isso que estou chamando de raciocínio, que o aluno pode pensar. Eu não estou mais falando de matemática, mas de qualquer coisa, qualquer problema que ele tenha na vida dele. Ele se depara com um problema, seja qual for, e tem uma maneira de resolver aquele problema, tem um raciocínio. Quando eu ensino matemática para ele, estou ensinando também uma outra forma de pensar. Então, eu acho que isso - não sei - o 
torna mais criativo. Acho que desenvolve o raciocínio, não só o conteúdo. Acho que não estou sendo muito clara...

P: É um assunto difícil mesmo... Então, vamos ver: você está me dizendo que, para você, raciocínio é uma forma de pensamento para resolver um problema? É isso?

A: Isso! Então, estou dizendo assim: de repente, um cara que não sabe de matemática vai resolver de certo modo, mas um cara que domina a matemática... De certa forma, eu acho que a matemática desenvolve esse raciocínio para ele, e ele começa a pensar em outras formas de resolver um problema. [...]

P: Bom, e o raciocínio lógico?

A: Acho que raciocínio lógico, eu penso muito na matéria de Lógica mesmo. Todos aqueles conectivos, mesmo, toda aquela linguagem de Lógica. Eu penso mais presa àquela linguagem própria da Lógica, presa à disciplina, mesmo.

P: Mas então só raciocina logicamente quem tem aula de Lógica?

A: Acho que não. Não. Às vezes, a pessoa raciocina logicamente mesmo sem ter tido aula de Lógica, eu acho.

P: Então, o que caracterizaria esse tipo de raciocínio que você chama de lógico?

A: Vou dizer uma coisa, mas acho que não é a única. Por exemplo, a questão de ter alguma coisa, e dessa coisa decorrer uma consequência. Mas tem outras coisas também, que agora não me ocorrem... E acho que não precisa a pessoa ter feito uma aula de lógica para saber isso. Ela pode perceber, mesmo sem ter feito matemática, por exemplo.

P: Mas, quando você diz que a matemática ajuda a desenvolver o raciocínio lógico inclusive... Como?

A: Nossa... [risos] Ah, por exemplo, quando a gente estava falando naquela aula sobre os números racionais. Só tem duas possibilidades na forma decimal: ou ele é finito, ou é uma dízima periódica. Naquela aula, a gente perguntava "por quê". Aí, eu disse: "porque o número racional é uma fração". Para conseguir uma forma decimal, eu tenho que dividir o numerador pelo denominador, e o resto da divisão é limitado, as possibilidades são finitas; portanto, uma hora vai repetir... Ou vai ser zero. Ou seja, eu estou raciocinando, de alguma coisa eu estou partindo, e ele está se desencadeando.

P: Esse raciocínio é lógico? 
A: Acho que é, porque uma coisa está desencadeando a outra. Aí, vai chegar a algum lugar.

\section{Professora B}

P: No questionário, você disse que a maior contribuição que a matemática pode dar à formação do aluno é a capacidade de raciocinar, de usar a lógica. Queria que você falasse mais sobre isso, e até pode dar exemplos.

B: É o produto final, na realidade. Quando dou uma aula de matemática, o trabalho que eu faço com o aluno é desenvolver o raciocínio lógico. O objetivo final é esse. Então, quando um aluno diz "eu odeio matemática", é porque a forma como a matemática foi mostrada a ele é do tipo: "você tem que decorar a tabuada, você tem que decorar essa coisa..." Você tem que mostrar que a matemática é só um instrumento para desenvolver o raciocínio. Então, eu adoro quando o aluno diz "eu odeio matemática".

P: É um desafio para você?

B: É um desafio. Aí, quando chega o fim do $1^{o}$ ano mesmo, eu percebo que consegui reverter isso. "Odeio matemática" passa a ser mais ou menos "eu gosto de matemática por sua causa”. Mas não é por minha causa: ele é que começou a ver a matemática de outra forma. Acho que esse é o tratamento que eu tenho que tentar colocar para o aluno.

P: Tenho percebido que muitas pessoas usam a expressão raciocínio lógico com frequência, mas cada uma usa essa expressão de uma forma um pouco diferente... Qualquer pensar é raciocínio lógico?

B: A vida da gente, ela é sempre de duas opções: você vai por um caminho ou por outro. É sempre assim, sempre. O respirar, você tem respirar ou não respirar. Só que respirar já é uma coisa automática. Eu sei que a minha mente pensa assim: se não respirar, eu vou morrer - mas já ficou no automático. Mas, de qualquer jeito, são duas decisões: ou você respira, ou não respira. Então, a vida é toda feita assim. Por exemplo, pisar na embreagem, você acaba incorporando e já fica automático. Meu filho, que dirige mais ou menos, raciocina: vou engatar a primeira, então, tenho que pisar na embreagem... Aí, usa o raciocínio. Só que, na hora em que você desenvolve esse raciocínio, passar a incorporálo. Quando o incorpora, é o desenvolvimento que a gente procura como ser humano. 
P: Deixa eu ver se entendi: quando se depara com uma tarefa, o aluno vai ter de raciocinar. Mas, depois que executa várias vezes a mesma tarefa, ele a incorpora. É isso?

B: Isso aí eu não estou falando sobre como resolver o exercício. É o dia a dia! O pensar é que ofaz incorporar. E, na hora em que incorpora esse fato, ele cresceu. Ele aumentou um grau de conhecimento. Isso faz parte da vida. Como é que a matemática ajuda nesse ponto? Quando você pensa assim: este é diferente deste [rabiscando dois triângulos], já está raciocinando. Este é menor que este. Se eu disser à minha neta, que tem quatro anos, "que é que você vê aqui?', ela vai dizer: "Este é mais pequeno". Aí, eu vou corrigir: "Este é menor"; mas ela já está raciocinando, porque já pensou nesse tamanho. Eu estou usando a matemática num sentido comparativo. Então, acho que a matemática faz você pensar, não exatamente com o cálculo. O cálculo ajuda você a resolver determinadas questões, mas o raciocínio está ali.

P: Como você bem disse, esse processo que você descreve está na vida. Mas, na matemática em particular, em sala de aula, me dê um exemplo. Por exemplo, nessa lista de questões de $8^{\mathrm{a}}$ série que você trouxe, de que modo os alunos raciocinaram?

B: Ah, eu já nem me lembro dessas resoluções. E, de todo jeito, isso varia muito de aluno para aluno. [...] Existem trabalhos fantásticos que você faz com transferidor, compasso e esquadro... Uma vez, eu perguntei: “como vocês vão dividir este pedaço, um pedaço qualquer, em sete pedaços?”. Só que eles não sabiam quanto media, então, não dava para dividir por 7. E eu disse: "aqui, vocês têm uma forma de trabalhar com o esquadro!". Com esquadro, eu vou pegar um reta qualquer e dividir em sete partes iguais: ela pode ter sete centímetros - um centímetro cada parte. E você vai juntar assim, ó... [mostra no papel] Não dividi em partes iguais? Só que eles não sabiam e perguntaram: "Pra que essa régua que parece um triângulo?" Então, eles não sabem qual é a utilidade. Esse raciocínio aqui, o marceneiro faz.

P: Mas, aí, voltamos àquilo que eu disse, que cada pessoa entende raciocínio lógico de um jeito. Se você me ensina isso, eu aprendo a fazer, a executar. Eu necessariamente raciocino logicamente para executar esse procedimento?

B: Na hora em que for aplicar, você tem de raciocinar. Quando pegar um pedaço de madeira, quero cortá-lo em nove partes iguais. Que é que eu vou fazer? Vou fazer o tamanho da madeira - aí, já estou usando o raciocínio lógico, né? Que é que ele vai tentar fazer? Vai tentar fazer esse negócio no papel, para ter o tamanho. Aí, ele tende a marcar na madeira depois ou já faz direto na madeira. Meu pai fazia direto na madeira. 
P: Seu pai era marceneiro?

B: Não, ele não estudou. Mas ele raciocinou, ele não teve alguém que lhe ensinasse.

P: Então, é nesse sentido a minha pergunta: se você ensina um procedimento a alguém e a pessoa apenas executa o procedimento, ela está raciocinando?

B: Lógico! Tudo na vida a gente tem que pensar, tudo que você não pensa, vai sair de qualquer jeito. Meu pai não aprendeu, mas ele criou a técnica dele, que, no fundo, é a mesma daqui. Ele não precisou de uma sala de aula, ele deduziu que, se fizesse assim...

P: E você vê diferença entre o raciocínio de quem deduz e o raciocínio de quem aplica?

B: Não, acho que é o mesmo. Acho que o tempo que meu pai demorou para descobrir isso talvez tenha sido maior. Sei lá quantos anos ele demorou pra descobrir isso aí. Agora, um aluno tem um facilitador, alguém dizendo "faz assim, que é mais fácil". Agora, vai depender dele desenvolver isso ou não. De qualquer jeito, tudo isso entra no raciocínio lógico. A matemática é só um instrumento que facilita isso.

\section{Professora C}

C: (...) Vem o pai e cobra de você: "o raciocínio lógico do meu filho não está bom”. Você fica ouvindo isso o tempo inteiro e pensa: "nossa, eu, que sou matemática, já não sei mais o que é isso!"

P: Isso é uma coisa que eu queria perguntar: de fato, todo mundo fala muito em raciocínio lógico, mas o que é isso? Quando você diz "raciocínio lógico", quando alguém usa essa expressão, o que isso evoca? Enfim, o que você entende que seja raciocínio lógico?

C: Bom, sem a gente falar da Lógica em si... Trabalhar com premissas e querer provar... De repente, você acha que pode provar uma coisa que você acha. Você provando dentro daquelas premissas, você vai construir uma lógica que prove x coisa, mesmo que seja absurdo. Você prova que é verdadeiro. Então, se você for trabalhar com isso, eu acho assim: é um jogo. Um jogo de palavras que o próprio homem pode criar.

P: Isso pra você é raciocínio lógico ou não é raciocínio lógico?

$C:$ É raciocínio lógico, não deixa de ser. Mas as pessoas dizem “2 +2 é 4, é lógico”. É lógico por quê? O que é esse logos, o que é essa razão? Você volta lá no Iluminismo... Então, o que é esse racional? Esse racional está destituído de emoção, de sensação, de 
percepção... Parece que é uma coisa mais fria. Assim: eu penso, eu provo. Se tem alguma contraprova, então eu não posso generalizar, né? E pronto, acabou. Se eu tenho esse tipo de raciocínio, então sou melhor que outras pessoas. Isso aparece muito socialmente... $\mathrm{Na}$ aula, dizem: "você é um crânio, você sabe matemática"... A gente não ouve esse tipo de coisa? Isso é meio absurdo.

P: Mas esse tipo de fala associada à matemática aparece mesmo quando não estamos falando de raciocínio lógico, não é?

C: Claro, mas as pessoas confundem o que seria raciocinar de maneira lógica, que eu não sei se seria uma coisa indutiva ou não. Isso não é muito claro para mim. Acabei não parando muito para pensar sobre isso. As únicas vezes em que eu pensei um pouco sobre Lógica foi quando eu conversava com o Newton da Costa. ${ }^{18}$ Eu dizia a ele: "Eu não sei nada!”. Uma época, quando dei aula numa faculdade, eles queriam que eu desse um curso de Lógica. Um curso de Lógica para um cara que não consegue compreender o que é uma sentença?! Na verdade, a gente vai cair numa coisa que eu venho estudando há muito tempo, que é a questão da representação. No mundo, tudo é linguagem, disse Platão. Você suprime a linguagem, e o que acontece? Não acontece nada, não se tem nada, nenhuma forma de se comunicar. Mas a linguagem também é uma prisão, porque, a partir das ideologias que acompanham a linguagem, você fica preso a isso ou àquilo. [...]

Não é fácil responder a uma pergunta direta acerca do que se entende por raciocínio lógico. Mais difícil ainda é responder a uma pergunta mais ampla - o que é raciocínio? -, como fez a professora A. De todo modo, notamos que, ao adentrar o campo específico do raciocínio lógico, duas das entrevistadas - professora $\mathrm{A}$ e professora $\mathrm{C}$ - recorreram à Lógica como referência para iniciar sua fala.

Com algum estímulo, a professora A pôde se desprender do contexto da disciplina de Lógica e arrolar a relação de causalidade como um dos aspectos que caracterizam o que ela entende por raciocínio lógico. A representação mental dessas relações causais parece fortemente associada a uma metáfora mecânica: sair de algum lugar (premissas), chegar a algum lugar (conclusões). A linguagem corporal da professora enfatizou essa representação.

\footnotetext{
${ }^{18}$ Newton da Costa é um célebre matemático brasileiro, reconhecido internacionalmente como um dos criadores das Lógicas Paraconsistentes.
} 
Sua fala sugere que ela vê a relação entre lógica e matemática como uma via de mão dupla: para tirar conclusões em matemática, é preciso raciocinar logicamente. E a matemática ajuda a potencializar o raciocínio lógico das pessoas, quer por ampliar seu repertório de resolução de problemas - e, portanto, de estratégias de raciocínio -, quer por constituir um campo que demanda a prática de raciocinar. Notamos que, em nenhum momento da entrevista, ela falou explicitamente na noção de prova ou de demonstração, mas, ao exemplificar como a matemática pode contribuir com o desenvolvimento desse tipo particular de raciocínio, a professora põe em jogo a pergunta "por quê?". Isso indica, que, mesmo inconscientemente, o raciocínio lógico evoca para ela uma prova com função de explicação.

Já na fala da professora $\mathrm{C}$, no referencial da Lógica, o raciocínio lógico liga-se fortemente à ação de "provar", não necessariamente no âmbito da matemática. Entretanto, ela parece ver isso de modo negativo. Tanto a fala quanto a expressão corporal e seu tom de voz nesse trecho sugerem certa rejeição ao tema, e a rejeição parece fundar-se na crença de que a lógica pode ser duplamente opressiva. De um lado, como uma opressão social, pois é comum associar-se a inteligência quase exclusivamente ao raciocínio dito lógico, que uns dominariam e outros não. De outro, como uma possível opressão da emoção, da percepção e da sensação. Ao não incorporar dados oriundos da emoção, da percepção e da sensação, a argumentação lógica presta-se a provar absurdos e se reduz a um jogo de palavras.

Um outro aspecto que merece destaque é o interesse da professora C pela representação e pela linguagem - que apareceu em outros momentos de nossa interação. A despeito da pertinência da discussão acerca da relação entre raciocínio e linguagem, a guinada para esse tema parece ter outra natureza. Nossa percepção é de que, ao questionar-se radicalmente sobre temas diversos - incluindo o raciocínio lógico -, a professora passa a vêlos como "não questões", ilusões provocadas pela própria linguagem, que, por essa razão, seria um tema de reflexão privilegiado.

A professora B se distingue das duas outras por não ter tomado a Lógica como referência para caracterizar o que há de específico no raciocínio lógico. Sua fala confirmou nossa interpretação sobre sua resposta ao questionário: para ela, raciocinar é raciocinar logicamente. Mais que isso, parece-nos que ela identifica o raciocínio com uma ampla gama de tipos de processo cognitivo. Por exemplo, a comparação visual entre figuras de diferentes tamanhos é raciocínio (lógico). Entretanto, de certa forma, sua concepção de raciocínio tem 
relação com a lógica dedutiva, em que só há dois valores possíveis para cada afirmação ou decisão: verdadeiro/falso, sim/não, isto/aquilo etc.

Outro aspecto da fala da professora B que nos chama atenção é que ela não distingue o raciocínio de quem deduz um procedimento do raciocínio de quem apenas o executa (ou, pelo menos, não os valora diferentemente). Com isso, a despeito do discurso de valorização da ação de raciocinar, o raciocínio é visto apenas como um meio para obter um produto (um conhecimento factual ou procedimental) - esse, sim, valorizado por ela. Dessa forma, um raciocínio feito por uma pessoa poderia ser transmitido a outra, sem nenhum tipo de perda. Ao "ensinar um raciocínio" a alguém, o efeito seria o mesmo que o obtido se esse alguém fizesse, sozinho, uma dedução. Na realidade, a primeira opção lhe parece mais vantajosa, já que poupa tempo. Assim, apesar de haver dito que a matemática é apenas um instrumento para aprender a raciocinar, ela acaba dizendo que, na realidade, é o raciocínio ("raciocinado" ou "aprendido") que é apenas um instrumento para obter novos conhecimentos que devem ser "incorporados" (matemáticos ou não). Para ela, a incorporação desses conhecimentos significa o ideal de desenvolvimento humano. Vislumbramos aí uma concepção tecnicista da matemática, vista mais como um conjunto de conhecimentos factuais e procedimentais que como uma atividade humana e, como expusemos no Capítulo 4, essa concepção não favorece o trabalho com argumentação e prova em sala de aula.

A professora D não participou da entrevista, e sua resposta ao questionário também não faz menção explícita ao raciocínio lógico. Portanto, temos poucos dados para interpretar suas ideias desse conceito.

\subsection{Relação entre raciocínio lógico e prova matemática}

O momento da entrevista serviu para colhermos novas evidências para nossa investigação e também para validar interpretações e dialogar abertamente com as participantes sobre nosso tema de pesquisa. Em dada altura da entrevista, depois de falar sobre nossos estudos sobre o tema da prova, salientando contribuição de Balacheff na distinção entre prova e demonstração, explicitamos a relação que entendemos haver entre prova e raciocínio lógico. As professoras foram convidadas a dar sua opinião sobre essa relação e a discuti-la. 
Segue-se a transcrição de trechos da entrevista das professoras A e B, que ainda não haviam relacionado explicitamente prova e raciocínio lógico.

\section{Professora A}

P: E você acha que validar um resultado, provar, executar ou ter de compreender um processo de prova favorece o desenvolvimento do raciocínio lógico?

A: Penso num tipo de prova que seria, por exemplo, a operação inversa. Eu acho que desenvolve, sim. Sei que existem outros...

P: E esses outros tipos...?

A: Sim, favorecem.

P: De alguma maneira, isso estava presente naquela explicação que você deu sobre o algoritmo da divisão? Aquela explicação tem um aspecto de prova, de validação...?

A: Você não está falando de validação como sinônimo de prova, não, né?

P: Estou, sim, mais ou menos. No sentido de dizer "isto vale, porque...".

A: Sim, acho que sim.

P: Então, você acha que processos de prova na atividade matemática favorecem o desenvolvimento do raciocínio lógico?

A: Sim.

P: Outra pergunta, um pouco diferente: você acha que, sem nenhum tipo de processo de prova, também poderia estar desenvolvendo o raciocínio lógico?

A: Olha, eu acho que sim. Mas acho que se perde alguma coisa. Perde. Ainda estou pensando na operação inversa como um tipo de prova, por exemplo. Acho que se perde uma parte importante: deixa-se de aprender algo de forma completa. O resultado final não é o fim do problema. Você ainda teria de duvidar, sim, daquela resposta, questioná-la: será que ela é verdadeira mesmo, será que ela é razoável?

P: Vamos levar essa discussão para outro contexto, também de sala de aula. Você, no $8^{\circ}$ ano, já ensinou o número de diagonais de um polígono, por exemplo?

A: Sim, já ensinei isso.

P: Tem uma fórmula, certo? 


\section{A: Tem uma fórmula.}

P: Como professora, você sente necessidade de provar essa fórmula para os alunos ou de fazer com que eles provem que ela vale?

A: Olha, eu não decoro fórmula nenhuma! [risos] Portanto, sempre demonstro.

P: E alguma vez você pediu que eles tentassem descobrir essa fórmula?

A: Sim, já fiz atividades para que eles construam a fórmula.

P: E você vê isso como um processo de prova, que ora você executa, ora o aluno?

A: Agora, você falando... Eu lembro que eles vão fazendo com polígonos diferentes $e$ percebendo que existe uma lógica...

P: Uma regularidade...

A: Isso. Alguns já vão conseguindo, mas, às vezes, como a variável para eles não é tão fácil, eu vou ajudando. Não são muitos alunos que conseguem construir a fórmula sozinhos, mas eles conseguem perceber a regularidade. Mesmo que não consigam escrever a fórmula, conseguem explicá-la. E isso eu acho extremamente importante, porque a fórmula tem significado para eles.

\section{Professora B}

P: Como essa fórmula [soma da PA] vai parar na mão deles?

B: É deduzida.

P: Quem deduz: eles ou você?

B: A gente vai fazendo "como é aqui?", "como é o $a_{1}$ ?", "como é o $a_{2}$ ?". "O a $a_{2}$ não é o $a_{1}+$ r? $O a_{3}$ o que é? [...] Aqui não vai dar o $a_{1}+2 r$ ? E quando a gente soma? Mas a gente não pode colocar o $a_{1}$ em evidência?" E você vai fazendo o desenvolvimento.

P: Então, você mostra da onde vem a fórmula?

B: É, porque eles não têm capacidade de fazer dedução.

P: Você acha que eles não têm?

B: Até teria, um ou outro até teria. 
P: Mas você acha que de modo geral não têm?

B: Não têm, não.

P: E você acha que não têm por quê?

B: Deficiência...

P: Mas por causa dessas outras deficiências [de conhecimento, ela falou antes] ou porque não estão acostumados com a necessidade de demonstrar?

B: Olha, demonstrar... Essa demonstração aqui, quando estudei no ensino médio (na época, era colegial), eu era obrigada a deduzir... Agora, eu poderia até colocar na prova: faça a dedução de tal coisa. Mas o que se pede? Você vai ensinar no ensino médio pra quê? Pra ele ter uma formação? Você vai prepará-lo para o ENEM? A maioria quer ENEM ali... Eu tenho que prepará-los para o ENEM. O ENEM... é muito dificil, nem sei se eles pedem dedução... Pode até ser que tenha uma dedução no meio de alguma questão, ali.

P: Você acha que, quando deduzem, eles estão aprendendo algo de importante, mesmo que não caia no ENEM?

B: Claro, né? Raciocínio.

Um aspecto importante na fala das professoras é que elas eventualmente incluem processos de prova em suas exposições em sala de aula. Além disso, a professora A propõe aos alunos atividades com potencial para demandar procedimentos de prova - como parece ser o caso das diagonais do polígono, por exemplo. Mas, até essa conversa, parece-nos que ela nunca havia relacionado essas práticas à da prova, que não via no contexto escolar. Isso fica claro, inclusive, em seu apego a um exemplo específico que criou (operação inversa como prova), numa aparente tentativa de tornar mais compreensível a tópico em tela. A não percepção desse tema parece dificultar um trabalho significativo com a prova, pois a intencionalidade é essencial para extrair o máximo potencial didático das atividades.

$\mathrm{Na}$ fala da professora $\mathrm{B}$, vemos outro tipo de dificuldade, relativa à crença de que os alunos, em geral, não são capazes de fazer deduções. Na próxima seção, discutem-se mais detalhadamente esses e outros problemas de um trabalho significativo com a prova.

A fala das professoras também permite inferir que, uma vez levantada a questão, todas concordam que trabalhar com provas em sala de aula seria um meio de desenvolver o raciocínio lógico. Entretanto, isso tem diferentes significados para cada uma delas. Por 
exemplo, a professora B relaciona a dedução ao uso do raciocínio - que reputa sempre lógico -, mas identifica raciocínio com vários processos cognitivos, o que confere pouco significado ao reconhecimento dessa conexão. Por outro lado, dada a percepção da especificidade do raciocínio lógico, a relação que fazem as professoras A e C entre esse conceito e a ação de provar torna-se mais significativa, de nosso ponto de vista.

Mas a percepção de que atividades relacionadas a provas desenvolvem o raciocínio lógico não implica automaticamente a valorização desse tipo de atividade em sala de aula. Já vislumbramos algumas dificuldades para essa valorização, que analisamos a seguir.

\subsection{Dificuldades para o trabalho com a prova matemática}

Entre as evidências coletadas em nossa investigação de campo, selecionamos as que podem lançar luz sobre uma das questões da pesquisa:

- O que pode dificultar que os professores de matemática da educação básica implementem um trabalho significativo com argumentação e prova em sala de aula?

Ao longo do período em que acompanhamos as professoras no projeto Ensino de matemática na escola elementar - OBEDUC, observamos diferentes dificuldades para o trabalho com argumentação e prova na educação básica e, para facilitar a análise, organizamolas em categorias. Assim, distinguimos dificuldades relativas:

- ao conhecimento matemático das professoras;

- a crenças e concepções sobre a prova matemática na educação básica;

- a crenças e concepções relativas à autoridade docente.

Ressaltamos que essas categorias não esgotam o problema, além de haver múltiplas conexões entre elas. Por isso, podemos dizer que, apesar de estar centradas em uma ou em outra categoria, as seções seguintes não estão livres de sobreposições. 


\subsubsection{Dificuldades relativas ao conhecimento matemático}

Logo no início da investigação, com a aplicação do questionário, ficou claro que a falta de certos conhecimentos matemáticos específicos, especialmente a não familiaridade com procedimentos de prova ou com formas tradicionais de produção do conhecimento matemático, poderiam dificultar o trabalho das professoras com a prova matemática.

No questionário, duas perguntas demandavam algum tipo de prova. A primeira era:

- Considere a seguinte afirmação:

SOMANDO DOIS NÚMEROS PARES, SEMPRE OBTEMOS UM NÚMERO PAR.

Pede-se que um aluno de $6^{\circ}$ ano decida se a afirmação é falsa ou verdadeira e justifique sua resposta. Como você espera que esse aluno responda à solicitação? $\mathrm{E}$ se fosse um aluno de $9^{\circ}$ ano? E você, como responde a essa solicitação?

Pretendíamos verificar como as professoras validariam a afirmação e não supúnhamos que alguma delas tivesse dificuldade para decidir se era uma afirmação verdadeira ou falsa. Pretendíamos ainda verificar se tinham familiaridade com possíveis respostas de alunos e se supunham alguma evolução do $6^{\circ}$ para o $9^{\circ}$ ano. Eis as respostas:

\section{Professora A}

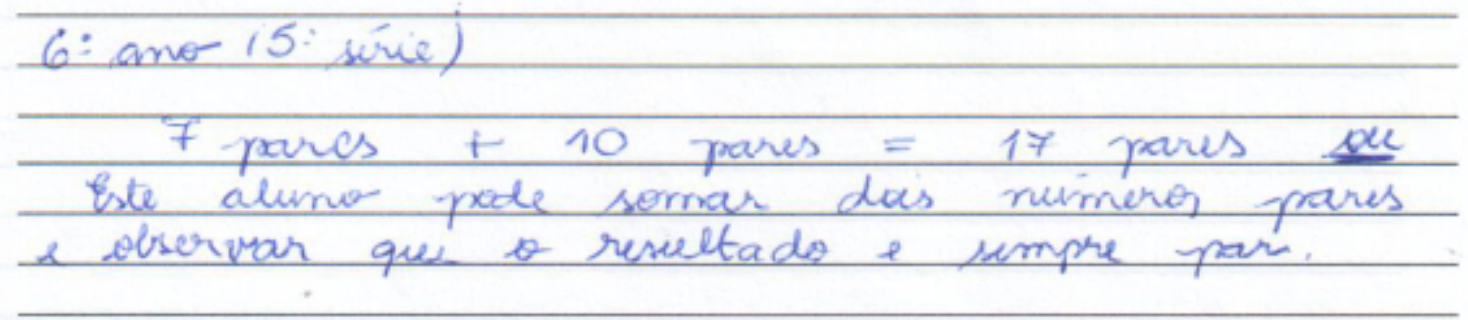

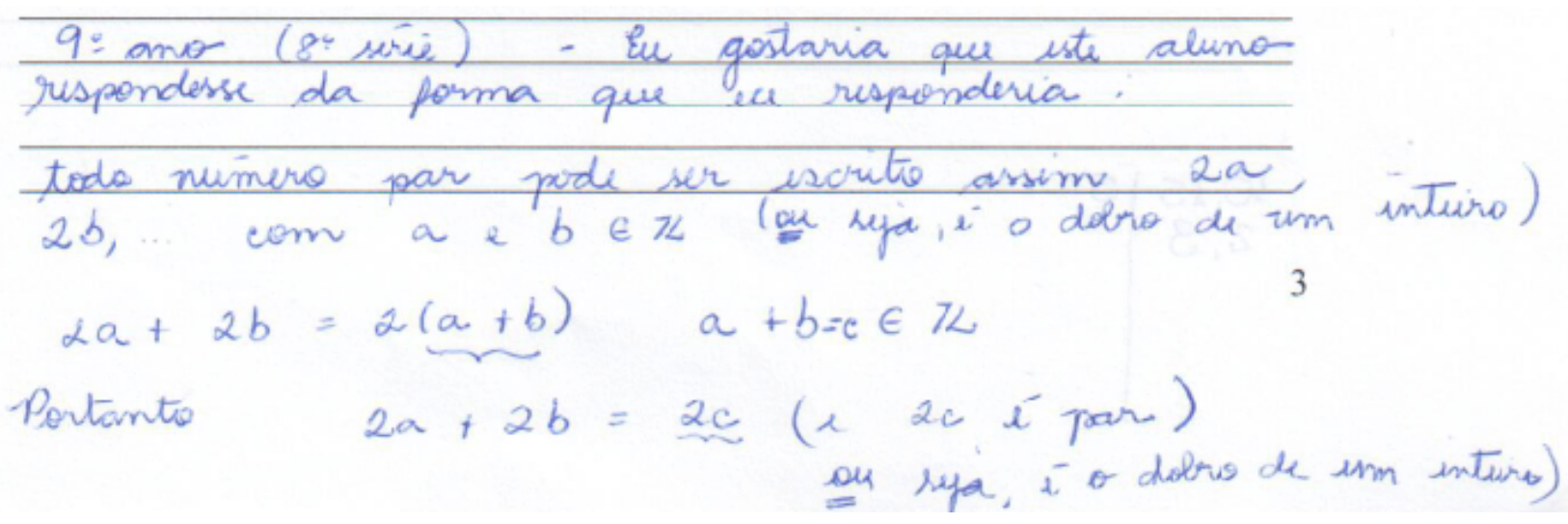




\section{Professora B}

Oaluno do 6-ani exempliticana para Lemonstrar pue íverdadecrio

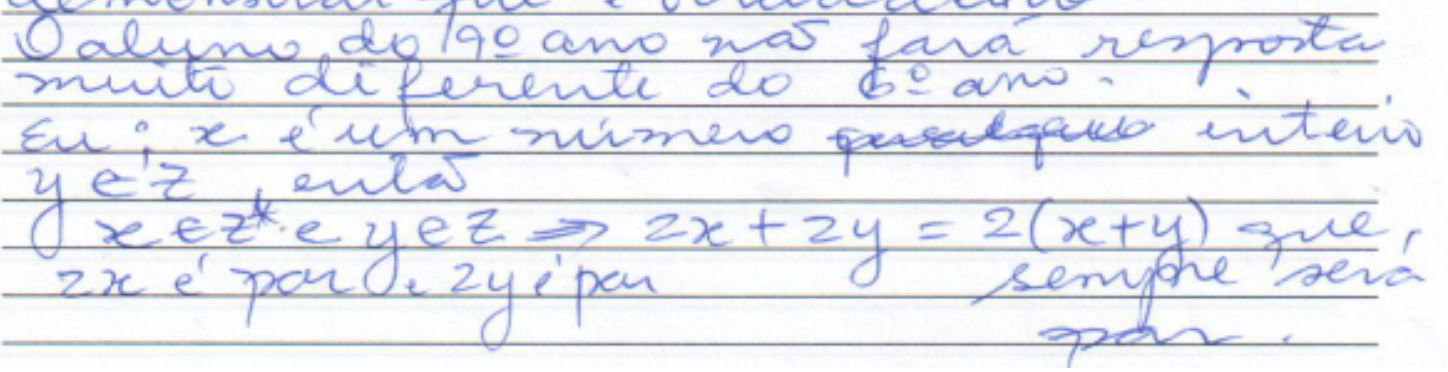

\section{Professora C}

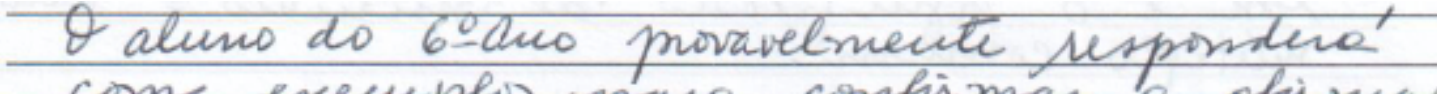
com exeuplos pare confirmar a ofinnase, nor pe meoupdudo com a considéncia da mesma; atrim como a aluno do 9:ano, teudo en irsta que os prodipmentos

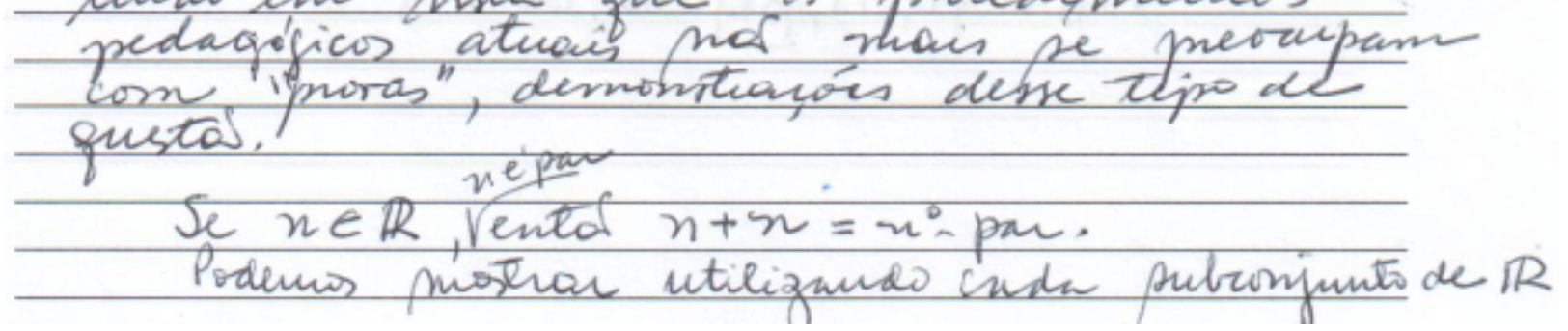

\section{Professora D}

Tow espero que men aluno do ge ano uspondo com exemplos operatowos smples eao mesmo tempo dando exem peos ao contravio do quie se pede pl povar. Iu tentaria morar atraves do arterio de deribilidade adndo exmplose contros exemplos

ex: $10+12=22$ logo se 22 é dursivel por 2 ele é par. Una contra exemplo seria pegar dous numeros não pares e somar, após duridir por 2.

ek: $15+3=18$ é durvivel por 2 mair tamber é dursuvel por 3. Entä́ para farzer esso afimaçás mostraria vários exemplos con algoritrmos de forma para estabelecer una conclustao. 
As professoras A e B conseguiram uma prova razoável para validar a afirmação sobre a soma de números pares (a professora $\mathrm{A}$, de modo um pouco mais preciso).

A professora $\mathrm{C}$ chega a esboçar uma justificativa (incompleta), com subconjuntos do conjunto dos reais, mas essa estratégia pouco promissora indica que ela não tem clareza sobre o fato de que o conceito de paridade só tem sentido no conjunto dos inteiros.

Já a professora D não deixou claro se considera a afirmação verdadeira ou falsa; sua resposta sugere que ela teve dificuldades para decidir. A afirmação - que, em outras palavras, diz que, se dois números são pares, então sua soma é par - é uma implicação. Nossa interpretação é que professora D esperava que, negando o antecedente ("dois números não pares"), também se negasse o consequente (resultado não par). Com isso, queria formular um "contraexemplo", em sentido diferente do usual, como uma espécie de "afirmação complementar" (soma de pares resulta par, soma de ímpares resultaria ímpar). Porém, como a soma dos dois ímpares também resultou num número par, isso parece tê-la confundido.

Embora relevante (dada a importância do conceito de paridade na Matemática), a dificuldade da professora $\mathrm{C}$ pode ser considerada pontual em relação a nosso tema de interesse. Isso significa que a expressão dessa dificuldade não implica necessariamente que, em outro tópico, ela não pudesse elaborar uma prova melhor. No entanto, a reposta da professora D indica problemas com raciocínio lógico e argumentação, de modo que nos parece muito difícil, por exemplo, ela conduzir um debate com os alunos a respeito de um processo de prova elaborado por eles. Mais difícil ainda seria planejar e elaborar atividades que visassem a elaboração de provas por parte dos alunos, uma vez que isso demanda a antecipação de dificuldades e impasses, bem como de seus possíveis encaminhamentos. Confirmando nossa percepção, em uma de nossas sessões de análise de prática, a própria professora D afirmou: "Eu não sei muito de lógica para levar isso para os alunos. Consigo resolver depressa problemas e desafios de revistinhas, mas, na escola, ninguém tem esse hábito. Exercícios de lógica cansam".

Também nos chamou atenção o fato de que as professoras $\mathrm{B}$ e $\mathrm{C}$ disseram que tanto o aluno do $6^{\circ}$ ano quanto o aluno do $9^{\circ}$ ano justificariam a afirmação com exemplos, e esta chega a dizer que o do $9^{\circ}$ ano não usaria outro recurso, dado que os atuais procedimentos pedagógicos não mais se ocupam de provas e demonstrações, deixando claro que percebe esse tipo de proposta como ausente da educação básica. Só a professora A destaca alguma 
diferença nas possíveis abordagens de alunos de $6^{\circ}$ e $9^{\circ}$ ano. Sua resposta sugere que ela tem mais familiaridade com diferentes tipos de argumentação possíveis para alunos dessas séries, além de indicar que ela idealiza um grau de formalização maior no $9^{\circ}$ ano.

A outra pergunta do questionário que demandava um processo de prova era:

- Suponha que você esteja ensinando a seus alunos de $7^{\circ}$ ano o método prático para obter o MMC entre dois números naturais e que eles lhe perguntem "por que funciona?". Como você responde?

Essa questão demanda um processo de prova que, segundo De Villiers (2001), tem função de explicação: por que funciona? Não se trata de dúvida acerca da validade, mas da necessidade de compreender o procedimento (que é bastante usual na matemática escolar). $\mathrm{Na}$ aplicação do questionário, ilustramos o que significava "método prático para obter o MMC": trata-se de colocar os dois (ou mais) números lado a lado, separados por vírgulas, com um longo traço vertical à direita. À direita do traço, linha a linha, registram-se os números primos pelos quais se podem dividir os números à esquerda. À esquerda do traço, abaixo de cada número, sucedem-se os resultados das divisões, linha a linha, quando possível. Quando não é possível dividir, apenas se copia o número da linha de cima. O procedimento termina quando todos os números à esquerda do traço ficaram iguais a 1. Então, o produto de todos os números primos anotados à direita do traço é o mínimo múltiplo comum procurado.

Seguem-se as respostas:

\section{Professora A}

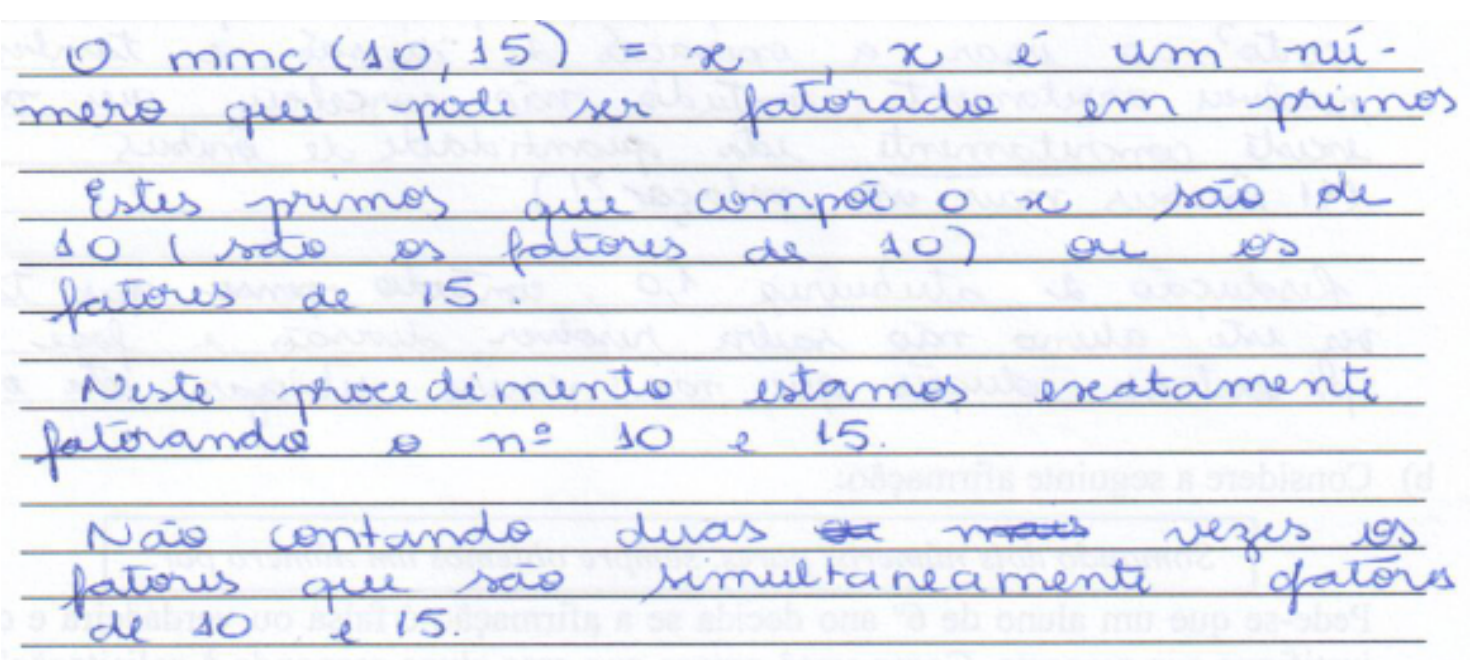




\section{Professora B}

Iunciona pois em ves de fatorar siparadamente, fedtor bes dois av mermo tempro. Já fico aom ospronte maiu dos nutmens Trimas

\section{Professora C}

A pergunta mais hequenter nos e' "porgue funcion", nias pasuel en devo dividir pers mimeros pimo. remos gue os alunos en 1-lugar tim deficuldad en entender o conceito de "minimo" pois seupre pos levado. a peurar no menor extre els, pinsanos entas netar a esse concicto e ifpeicarque

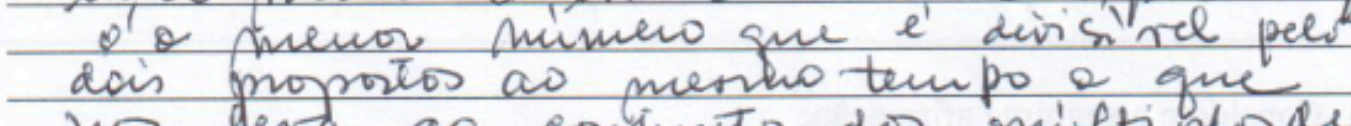

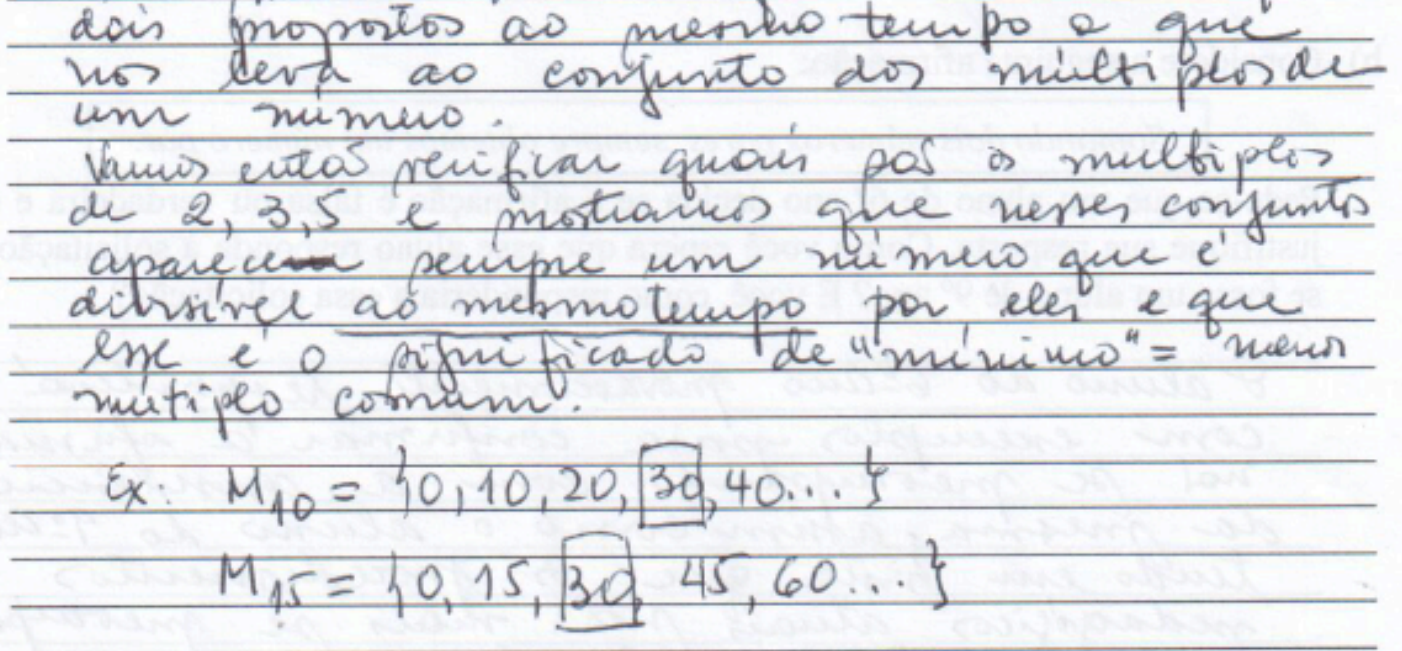

\section{Professora D}

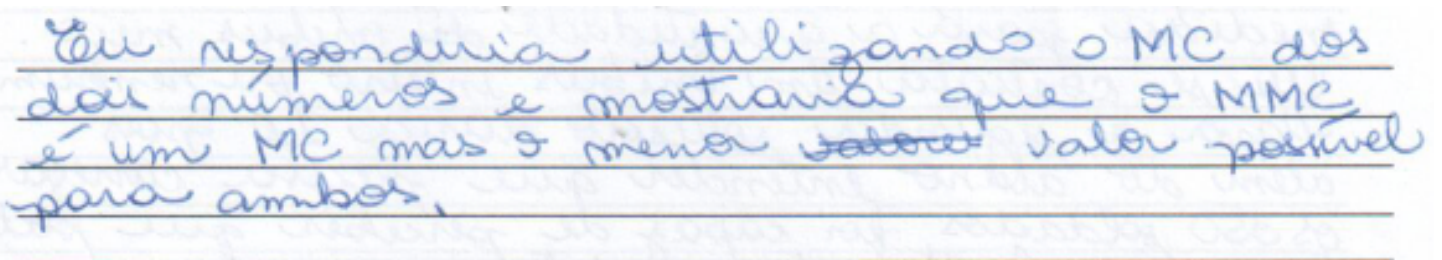

As professoras C e D desviaram-se da pergunta, não explicando o procedimento. Ambas deixaram-no de lado e apresentaram uma abordagem alternativa para a determinação do MMC, calcada no seu significado. A despeito de as abordagem serem possivelmente adequadas, a fuga ao tema sugere uma de duas possibilidades: ou essas professoras tiveram 
dificuldade para explicar o procedimento, ou as dificuldades conceituais de seus alunos com relação ao $\mathrm{MMC}$ lhes parecem tão mais prementes que elas não conseguiram focalizar o que se perguntava. Essa última alternativa é reforçada pela resposta da professora C: “A pergunta mais frequente não é 'por que funciona?'”.

Qualquer uma das alternativas (ou uma combinação de ambas) indica problemas no trabalho com provas em sala de aula. A primeira, novamente, indica dificuldades relativas ao conhecimento matemático, específico ou não. Porém, se a segunda interpretação for a mais correta, isso sugere que problemáticas ligadas à validação do conhecimento são consideradas secundárias, em função de eventuais dificuldades ou defasagens de conhecimentos factuais e procedimentais dos alunos.

Já as respostas das professoras A e B indicam alguma compreensão do procedimento. Mas, para nós, ambas demandariam revisões e aprofundamentos para ser compreendidas por quem ainda não compreende a lógica por trás do procedimento. Em particular, a resposta da professora B parece supor que o interlocutor esteja questionando o procedimento descrito frente a outro, em que os números seriam fatorados separadamente.

Assim, se as respostas das professoras A e B não traem (apresentam?) dificuldades específicas relativas ao conhecimento matemático, sugerem que, pelo menos quanto ao procedimento em pauta (recorrente na matemática escolar), elas nunca se haviam perguntado por que vale.

Como já salientamos, não é só a falta de conhecimentos matemáticos factuais ou procedimentais que podem dificultar o trabalho com a prova matemática em sala de aula, mas também o desconhecimento acerca de processos de prova e demonstração em matemática. Os próprios vocábulos associados ao assunto podem revelar pouca inserção na cultura matemática, configurando, para nós, uma lacuna no conhecimento matemático desejável para um professor - que afeta diretamente o tipo de trabalho que examinamos aqui. Ilustramos esse ponto com a reprodução livre de uma conversa que tivemos numa das sessões de análise de prática.

coordenadora $(\mathrm{O})$ : E nas operações matemáticas, há lógica?

professora D: Para mim, sim. Para os alunos, nem tanto. Por exemplo, uma equação é uma balança. Eu tento mostrar a eles que, por exemplo, se eu e um deles estivéssemos numa balança, um ia equivaler ao outro. 
O: Você está procurando maneiras de justificar os procedimentos que são usados na resolução de equações, é isso?

D: Isso. Tanto faz se o x está de um lado ou de outro, porque é uma igualdade. Eles já estão começando a pensar, mas é porque a gente vem demonstrando.

P: O que é "demonstrar" para você?

D: É mostrar mesmo. Usar exemplos concretos: usar canetas.Também tento ver muito onde é aplicado o conteúdo, para eles saberem que tem serventia.

Notamos que o sentido que a professora $\mathrm{D}$ dá à palavra demonstração não corresponde ao que se lhe dá no contexto da Matemática (algo similar ocorreu na pesquisa descrita por Almouloud et al. [2008], citada na Introdução). Sendo o conceito de demonstração tão importante nessa ciência, o uso inespecífico da palavra, sobretudo em ambiente acadêmico, revela pouca inserção da professora na cultura matemática. Para nós, isso configura uma lacuna no conhecimento matemático da professora que lhe dificulta refletir com autonomia sobre a pertinência ou a importância de levar a cabo um trabalho com argumentação e prova em sala de aula.

\subsubsection{Dificuldades relativas a crenças e concepções sobre a prova matemática na educação básica}

Abrimos esta seção com um episódio que se passou durante uma das sessões de análise de prática, novamente envolvendo divergências sobre vocábulos associados à problemática da argumentação e da prova em matemática. Estavam presentes as quatro professoras participantes, uma segunda mestranda e a coordenadora do projeto (orientadora desta dissertação). Uma das metas da reunião era compartilhar com as professoras nossa temática de investigação. Começamos dizendo que estávamos estudando argumentação em matemática e que tínhamos particular interesse em processos de prova ou demonstração cabíveis na matemática escolar. A professora $\mathrm{C}$ tomou a palavra e disse: "Eu não gosto da palavra prova. Acho mais adequado falarmos em avaliação". Percebendo o equívoco, fizemos menção de intervir, mas a coordenadora indicou que apenas observássemos. A partir daí, o tema da avaliação mobilizou intensa e instantaneamente todas as professoras participantes, de modo que adiamos nosso objetivo inicial. 
Esse episódio revela ao menos dois aspectos dignos de nota. O primeiro é que a palavra prova, no sentido matemático, está tão distante da prática docente das professoras que, mesmo tendo sido usada ao lado de argumentação e demonstração, foi tomada em seu sentido de avaliação. E o segundo é que, para as professoras participantes, numa hierarquia de prioridades, o tema da avaliação educacional está muito à frente do da prova matemática. Mais adiante, na entrevista, relembrando o equívoco, a professora A confirmou que a discussão sobre avaliação era mais útil e parecia mais urgente em seu dia a dia.

Diversas evidências colhidas na investigação reforçaram nossa percepção de que as professoras participantes têm crenças que relegam a prova matemática na escola. Algumas delas já foram brevemente citadas na seção anterior. Por exemplo, retomando um trecho da entrevista com a professora B:

P: Então, você mostra da onde vem a fórmula?

B: É, porque eles não têm capacidade de fazer dedução.

P: Você acha que eles não têm?

B: Até teria, um ou outro até teria.

P: Mas você acha que de modo geral não têm?

B: Não têm, não.

P: E você acha que não têm por quê?

B: Deficiência...

P: Mas por causa dessas outras deficiências [de conhecimento, ela falou antes] ou porque não estão acostumados com a necessidade de mostrar?

B: Olha, demonstrar... Essa demonstração aqui, quando estudei no ensino médio (na época, era colegial), eu era obrigada a deduzir... Agora, eu poderia até colocar na prova: faça a dedução de tal coisa. Mas o que se pede? Você vai ensinar no ensino médio pra quê? Pra ele ter uma formação? Você vai prepará-lo para o ENEM? A maioria quer ENEM ali... Eu tenho que prepará-los para o ENEM. O ENEM... é muito difícil, nem sei se eles pedem dedução... Pode até ser que tenha uma dedução no meio de alguma questão, ali.

Vê-se que a professora B acredita que, em geral, os alunos não são capazes de fazer deduções. (Nessa discussão em particular, ela se referia a alunos de $1^{\circ}$ ano do ensino médio.) Para ela, essa suposta incapacidade de deduzir não se explicaria pela falta de um trabalho 
dirigido ao desenvolvimento dessa habilidade, mas pela defasagem de conhecimentos que se haveria acumulado desde o ensino fundamental. Assim, parece-nos que a professora B acredita que só é possível fazer deduções se o resto dos conteúdos estiver garantido e, portanto, que não seria possível trabalhar com argumentações e provas até que se sanassem tais defasagens. Consequentemente, presumimos que a habilidade de dedução seria vista como um fruto "natural" desses outros conhecimentos, e não da própria prática da argumentação.

Outro aspecto relevante na fala da professora B diz um certo pragmatismo, que a leva a contrapor exigências distintas. Em sua visão, preparar os alunos para o Exame Nacional do Ensino Médio (ENEM) se contrapõe a um trabalho com provas e demonstrações, já que elas não são explicitamente exigidas nesse exame, composta apenas de questões de múltipla escolha. Essa crença nos parece apoiada num equívoco, pois nossa concepção é que o trabalho com argumentação e prova em matemática não só vale por si mesmo, mas é um meio para aprender matemática de uma forma mais profunda do que vem ocorrendo. Portanto, melhoraria o desempenho dos alunos no ENEM, cuja matriz de avaliação baseia-se em competências e habilidades, e não em conteúdos factuais ou procedimentais específicos.

Durante a entrevista, também a professora A expressou a crença de que, por mais interessante que seja, o trabalho com prova matemática compete com outros objetivos que, em sua visão, muitas vezes são prioritários. Além disso, mais articuladamente que a professora B, ela também levanta o problema da defasagem de conteúdos como uma dificuldade ao trabalho com provas. Segue-se o trecho da entrevista em que debatemos o tema:

\section{Professora A}

P: Conversando com outros professores, eu ouvi, sobre provas e demonstrações, que "Uma demonstração, de vez em quando eu faço. Por exemplo, na soma dos termos da PA, eu sempre faço".

A: Ah, eu também. Eu nunca dei aula no ensino médio, mas vou dar agora, já vi que tem e vou fazer.

P: Mas aí eu perguntei: e os alunos? Eles seriam capazes de fazer? "Não, não seriam." Mas você acha que deveria ser um objetivo da matemática escolar? Não digo demonstrações formais, mas pequenas provas informais... O que você acha? 
A: Eu acho que sim. Mas, nesse exemplo que você deu, a dificuldade do aluno talvez seja ele não ter entendido direito sistemas. Mas eu acho que vale a pena tentar... Se ele não conseguir, se o problema dele são os sistemas, você tem que dar uns sisteminhas e, mesmo assim, tentar. Mas eu acho ainda que, além disso, outro problema que eu sinto - seria muito preconceito da minha parte ficar falando do ensino médio, - mas, se você pega alunos maiores, percebe que faltam ainda mais pré-requisitos. É diferente de você pegar uma $5^{a}$ série, em que faltam menos pré-requisitos, porque eles têm menos conteúdos, então, você acha que dá conta do que eles não aprenderam ainda. E, quando os alunos vão avançando, você tem o desespero de falar "meu deus, será que eu vou dar conta daquilo tudo que eles deveriam saber e não sabem?".

P: Então, quando escuta essa minha fala, você diz "meu deus, agora querem que eu ensine ainda mais uma coisa para alunos que já têm tantas defasagens"? É isso?

A: Não é só essa questão, e eu também não quero dar desculpas, mas tem quarenta alunos, né? E são alunos muito diferentes. Então, às vezes, parece que você tem de escolher pra quem vai dar aula... Mas eu acho que vale a pena parar, sim, e tentar fazer os alunos fazerem.

P: Eu dei um exemplo do ensino médio, mas antes também dei um do ensino fundamental... Então, quando pergunto se você acha que esse seria um objetivo pertinente para a matemática escolar, não me refiro especificamente ao ensino médio. Eventualmente, dependendo do assunto e do grau de complexidade, você poderia trabalhar com um processo de prova no $6^{\circ}$ ano.

A: Eu falei do ensino médio, mas eu digo assim: conforme vai avançando mais, você percebe que faltam mais pré-requisitos e fica com receio de não dar conta. Acho que é onde o professor, às vezes, faz escolhas que, para ele, vão demandar um tempo menor. Por exemplo, o aluno vai fazer uma prova da soma da PA, mas a soma da PA não é problema, o problema é que vai faltar para esses alunos algum pré-requisito... E ele vai ter de ensinar esses pré-requisitos para esses alunos.

P: Mas esse é só um exemplo. Há outros conteúdos que poderiam colocar em ação um processo de prova. Por exemplo, os números racionais: por que eles têm essa forma? Demanda um processo de prova - que você fez há pouco - mostrar por que eles têm a forma decimal finita ou infinita e periódica...

A: Nesse caso, é mais fácil. É verdade. 
P: Então, existem processos de prova que podem envolver conteúdos nos quais os alunos têm defasagens e existem outros que não. Isso varia de uma turma para outra. Independentemente de onde você escolhe "enganchar" esse tipo de atividade - dependendo de onde você avalia que será menos custoso -, eu quero saber se você acha que é importante que ela esteja presente.

A: Eu acho importante que ela esteja presente... [expressão de dúvida]

P: Mas?

A: [risos] Mas acho que você tem de fazer escolhas. Esse tipo de atividade deveria estar presente sempre, mas, diante da realidade, de você ter muitos alunos em sala de aula, alunos com dificuldades diferentes... Você tem de escolher em que momento vai fazer isso.

P: Então você está me dizendo que é interessante, mas não é sua prioridade.

A: Não é uma coisa para se fazer com frequência, porque vai demandar tempo.

P: Essa é uma preocupação para você?

A: Se eu dissesse que não é, estaria mentindo.

P: É uma preocupação válida... Mas, quando a gente fala em tempo, parece que ele sempre falta, não? Então, me parece que, no fundo, a questão é: quais são nossas prioridades? Você pode priorizar ensinar procedimentos, trabalhar a compreensão dos procedimentos, a execução, a aplicação prática da matemática... Você pode, eventualmente, gastar um ano inteiro trabalhando todos os conteúdos do livro, mas só o procedimento, "como se faz", deixando de lado "por que é assim?".

A: É, eu acabo valorizando mais algumas coisas que outras. Por exemplo, a equação é algo que eu valorizei. Então, agora estou me planejando para esse ano e eu sempre me agarro àquilo que acho mais importante. [...]

P: Veja se é isso: você acha que a ação de justificar, argumentar em favor de um resultado não é uma prioridade, na maioria das vezes.

A: Não sempre. Em alguns momentos, eu vou fazer isso, mas, em outros, vou deixar de lado.

Em certa medida, estamos de acordo com a professora A: é preciso fazer escolhas e, no contexto real da sala de aula, a prova matemática nem sempre é a prioridade - embora não nos pareça adequado que ela esteja de todo ausente. Mas, analisando a fala da professora A em seu contexto, não podemos deixar de considerar que ela talvez dê a esse tipo de atividade 
ainda menos prioridade do que explicitou na entrevista - talvez, por empatia, ela tenha feito na entrevista concessões demais a nosso tema de investigação. Essa percepção é reforçada pela análise que fizemos do material (de $8^{\circ}$ ano) que a professora A nos cedeu. De fato, como ela mesma salientou na entrevista, a prioridade foram as equações, de uma forma que nos pareceu bastante focada nos procedimentos de resolução - incluindo a preocupação em explicar aos alunos a validade de tais procedimentos, por meio da analogia com a balança, no caso das polinomiais de $1^{\circ}$ grau. Por outro lado, esse material não permitiu inferir que a professora tenha proposto situações de validação em que os alunos tivessem maior protagonismo - o caderno e as fichas de atividades continham basicamente listas de exercícios procedimentais. Aqui, estamos além das crenças: entramos no campo das diferentes concepções de ensino de matemática e, até mais além, no dos valores. Vale mais instaurar uma certa atitude crítica e desenvolver a habilidade relativa à argumentação em matemática ou usar o tempo disponível para ampliar o repertório matemático factual e procedimental dos alunos, especialmente num contexto de acúmulo de defasagens? São questões que sempre se podem responder de diferentes formas. Seja como for, embora se preocupe em explicar aos alunos por que valem determinados resultados e procedimentos, concluímos que a professora A costuma aplicar atividades calcadas numa concepção de ensino de matemática prioritariamente tecnicista, que não favorece o trabalho com argumentação e prova, conforme discutimos no Capítulo 3.

As professoras também deixaram entrever a crença de que provas ou demonstrações não seriam capazes de despertar o interesse dos alunos. Reproduzimos livremente parte de uma conversa com a professora $\mathrm{D}$ numa das sessões de análise de prática:

D: Na faculdade, demonstração era aquela coisa algébrica... [linguagem corporal mostrando aversão] Meus alunos não sonham, eles não imaginam. Por isso, eu prefiro trabalhar de modo lúdico. [...]

P: Você está dizendo que as demonstrações que você aprendeu na faculdade não despertariam o interesse dos seus alunos e que esse é seu principal objetivo? É isso?

D: Isso. Na minha escola, as pessoas generalizam, dizem que os alunos não são capazes. Eu quero estimulá-los, fazê-los acreditar que eles são capazes.

Ao lado da aversão com que ela pronunciou a primeira frase, a fala da professora D remete ao Capítulo 3 desta dissertação, quando fizemos uma breve análise do tratamento dado 
às demonstrações nos cursos de formação inicial de professores de matemática. Ali, concluímos que a forma como a demonstração é geralmente abordada nesses cursos oscila entre o formalismo, que identifica a matemática escolar com a acadêmica, e o tecnicismo que exclui a argumentação e a prova de um fazer matemático significativo. Assim, ficará a cargo do professor ressignificar ou não a prova matemática, para que ela seja vista e explorada em toda a sua potencialidade pedagógica. Os caminhos profissionais da professora $\mathrm{D}$, até o momento, não a levaram a construir tal ressignificação.

Além das crenças de que os alunos não são capazes de resolver ou não teriam interesse por atividades envolvendo provas ou demonstrações (tomadas como equivalentes), há outras que também podem impedir a proposição desse tipo de atividade. Trata-se da crença de que a única finalidade de um processo de prova é a validação do conhecimento. Nas reuniões de MAT-1500, durante a discussão das sequências didáticas que os licenciandos formulavam, muitas vezes procuramos introduzir o problema da prova lançando perguntas como "por que vale?", “como justificar isso para os alunos?", “como os alunos poderiam validar isso?” etc. Nesse tipo de situação, diversas vezes a professora B respondeu algo como: "não precisam se preocupar com isso, eles vão aceitar". Em todos os casos, ela queria dizer que os alunos acreditariam no que ela dissesse (ou no que os licenciandos dissessem). Ora, se se tratar apenas da função de validação ou convencimento da prova matemática, o ambiente escolar é realmente impróprio para a implementação de um trabalho significativo com provas e demonstrações, dado que a maior parte dos resultados está validada de antemão, seja pela autoridade do professor, do livro didático ou mesmo do sistema escolar como um todo. Essa percepção da prova como desnecessária prevalecerá especialmente se não estiver instaurada uma robusta prática de resolução de problemas - em que, muitas vezes, os alunos devem validar suas soluções -, se não se costuma pedir que os alunos criem conjecturas e se o ensino está centrado apenas em procedimentos e problemas-modelo, numa concepção tecnicista. Acreditamos que conhecer diferentes funções da prova ensejaria o reconhecimento também da pertinência de trabalhar com provas matemáticas em sala de aula, para explicar resultados e procedimentos, comunicar resultados e mesmo induzir pequenas descobertas matemáticas. 


\subsubsection{Dificuldades relativas a crenças e concepções ligadas à autoridade docente ou à autonomia intelectual dos alunos}

As dificuldades analisadas nesta seção não guardam paralelismo com as demais, em termos de especificidade/abrangência. Trata-se de um tipo mais específico, e nossa análise se baseia na narração de um único episódio, muito significativo e que mobilizou intensa e até apaixonadamente todos os participantes.

Numa das sessões de análise de prática, no segundo semestre de 2014, a professora B contou que, em 2015, lecionaria em turmas de $6^{\circ}$ ano e compartilhou com a equipe uma de suas preocupações. Ela supunha que os alunos não chegariam ao $6^{\circ}$ ano dominando o algoritmo tradicional da divisão e se queixava de que o chamado "método das subtrações sucessivas" - a que supunha habituados os alunos - era muito demorado. O debate acerca da necessidade de rapidez prosseguiu com a contribuição das outras. A professora $C$, por exemplo, defendeu que a rapidez nos cálculos é necessária para que os alunos possam ser mais fluentes em tarefas mais complexas. Também participamos da discussão, colocando outro aspecto: embora mais breve, o algoritmo tradicional da divisão nem sempre é compreendido. Os passos podem parecer arbitrários, se não se fizer um trabalho sobre seus significados - e isso nem sempre é feito. Seguiu-se, então, uma discussão a respeito de como “explicar" o algoritmo. Como não temos essa discussão registrada em áudio, reconstituímos livremente a fala dos participantes e as anotações que fomos fazendo na lousa da sala de reunião. (Acreditamos que, embora um pouco imprecisa, a reconstituição será mais eficaz que uma narrativa indireta para descrever aspectos importantes da discussão.)

P: Como explicar o algoritmo tradicional da divisão? Não é simples...

B: Ora, por exemplo, 1.207 dividido por 11. A gente vai por algarismos. Como 1 não se divide por 11 - é menor -, tem que pegar o 12 [fazendo um arquinho sobre o 12 de 1.207]. 12 dividido por 11 dá 1 e sobra 1.

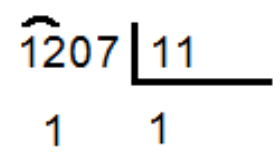

Agora, tem que pegar o 1, mas também não dá pra dividir por 8, então baixa o 0.

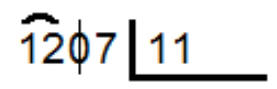

101 
Então, tem que dividir 10 por 11, mas também não dá. Quando você já baixou e mesmo assim não dá, tem que colocar um 0 no quociente e dai baixa mais um algarismo. Vai abaixar o 7 .

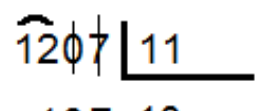

10710

Agora, quanto é 107 dividido por 11? Quantas vezes a gente faz o 11 pra chegar a 107 (ou perto)? Dá 9 e sobram 8. E, como 8 é menor que 11 e não tem mais nada para baixar, a conta termina assim, com resto. 1.207 dividido por 11 é 109 com resto 8.

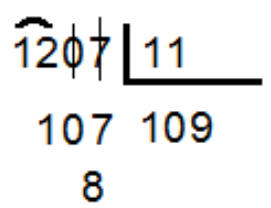

P: Ok. Mas você descreveu os passos, não explicou os passos. Por que se faz cada um deles? Qual é o sentido de cada um deles? Por exemplo, você disse: quando você já baixou e mesmo assim não dá, tem que colocar um 0 no quociente. Por que colocar esse zero no quociente?

B: Porque esse é o jeito certo de fazer, ué!

P: Claro, nós sabemos que dá certo fazer assim. Mas por que dá certo?

B: Se não fizer assim, fica errado. Por isso, tem que fazer assim. Todo mundo que presta atenção, sabe que é assim.

P: Está bem. Então, vamos fazer de conta que eu sou sua aluna, no $6^{\circ}$ ano. Você disse que é assim e eu acredito em você. E eu sou boa aluna, eu presto atenção e memorizei os passos, as regras que você disse que fazem dar certo. Então, eu chego ao $7^{\circ}$ ano, e tenho que aprender divisão no conjunto dos racionais, não mais no conjunto dos inteiros. Aí, tenho que fazer, por exemplo, $127: 8$. Faço tudo igual até aqui:

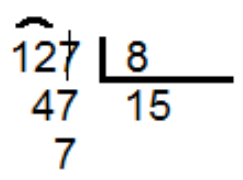

Mas me ensinaram que, como 7 não dá para dividir por 8, tem que colocar uma vírgula depois do 15 e acrescentar um 0 ao lado do 7 . Aí, dá para continuar:

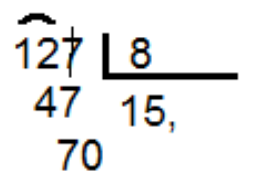


Então, o 8 cabe 8 vezes no $70 \ldots$ Dá, 64 e sobram 6:

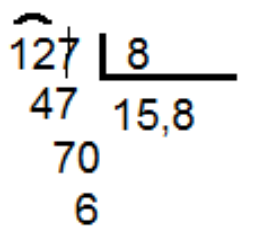

E agora? 6 é menor que 8... Não posso mais colocar vírgula. Talvez eu tenha que colocar um 0 no quociente. Lá naquele primeiro exemplo, quando você tinha feito tudo o que dava e não funcionava, precisava colocar um 0 no quociente para poder continuar. Vou fazer igual e, para continuar, acho que tem que colocar um zero no resto também.

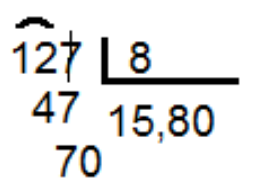

60

Pensando desse jeito, minha conta vai ficar assim:

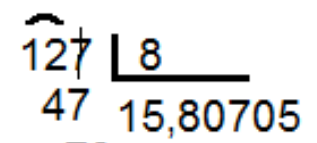

70

60

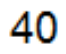

0

B: Não, está errado! Você não deve ter prestado atenção às aulas do $7^{\circ}$ ano! Quando você coloca vírgula, não precisa mais colocar zero no quociente.

P: Mas por quê?

B: Porque fica errado. Cada caso é de um jeito. Com vírgula, não é pra colocar zeros no quociente. Você não sabe isso?

P: Estamos fazendo de conta que sou uma aluna sua, lembra? Por que essa aluna teria de saber?

C: Se você fizer a operação inversa, 15,80705 x 8, vai poder checar o resultado $[15,80705 \times 8$ $=126,4564]$. Eu estimulo os alunos a conferirem se o resultado está correto. Esse tipo de erro é muito comum.

P: Está bem, então, quando a conta é com vírgula, não preciso ficar colocando zeros... Então, vamos dividir 210 por 20. [Fazendo passo a passo.] 


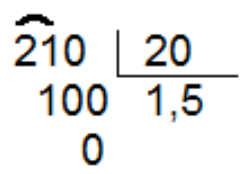

B: Está errado!

C: Você tem que estimar antes de dividir. Não pode ser 1,5. Se $2 \times 20$ é 40, como 1,5 $x 20$ poderia dar mais de 200?

P: É verdade, eu concordo com você. Mas continuo sem saber como usar corretamente o algoritmo tradicional da divisão, que vocês valorizaram no início da reunião. O método longo é lento, mas me parece mais seguro. A menos que eu consiga entender porque é que às vezes tem que colocar zero, às vezes não... Parece muito confuso e arbitrário sem uma explicação, uma justificativa. Só com a regra, são muitas situações diferentes a considerar.

A: Eu acho que posso explicar por que coloca ou não coloca... Na divisão de 210 por 20, por que a gente coloca o arquinho no 21? Tem 21 dezenas em 210 e a gente está pegando essas 21 dezenas para dividir por 20. Desse jeito, eu sei que o resultado vai dar em dezenas. Já sei quantas casas terá de ter a parte inteira do meu quociente, vai ter duas: dezenas e unidades.

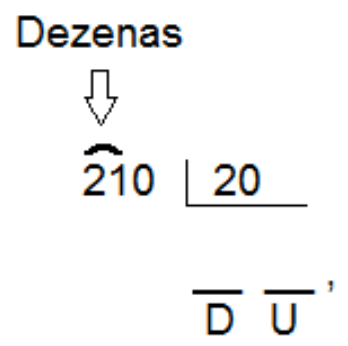

Quanto dá 21 dezenas divididas por 20? Dá uma dezena, mas ainda sobra outra dezena.

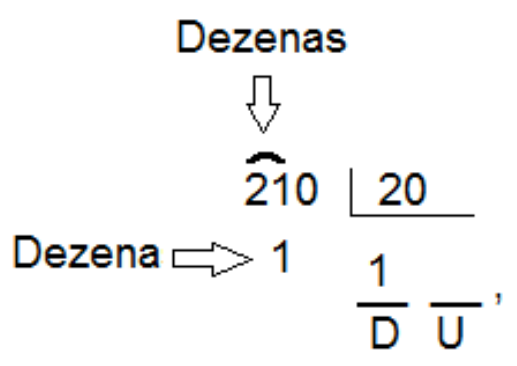

Agora, essa dezena que sobrou, eu não consigo dividir por 20, então eu transformo em 10 unidades. Se, em vez do zero [apontando o 0 do 210], eu tivesse outro algarismo, que também indica unidades, poderia juntar com as dez unidades que tenho ali no resto; por isso se baixa o algarismo. Mas, nesse caso, não fará diferença; vamos ficar só com as 10 unidades mesmo. Agora, quanto dão 10 unidades divididas por 20? Dá 0 unidades! Não 
consigo distribuir nem uma única unidade para cada um dos 20. Então, eu anoto zero na casa das unidades.

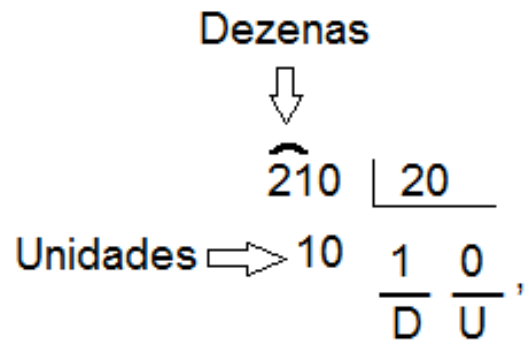

Agora, eu vou trocar aquelas 10 unidades por décimos de unidade. Em 10 unidades, tem 100 décimos. Então, eu vou dividir 100 décimos por 20, que dá 5 décimos. Por isso, agora o resultado vai depois da vírgula, porque são décimos.

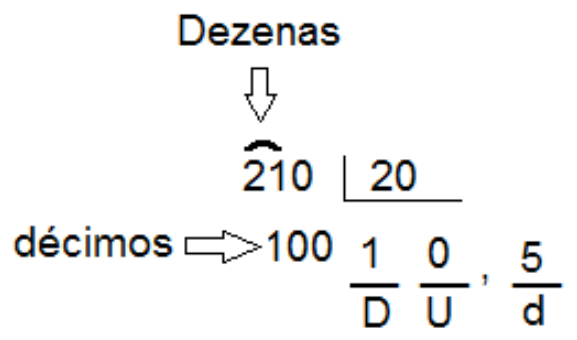

P: Para mim, essa é uma explicação que permite entender as razões por trás de cada passo.

Vocês percebem a diferença entre explicar e descrever os passos do algoritmo?

C: Sim. Eu adorei! Não me lembrava mais disso. Obrigada! [agradecendo à professora A]

B: Acho que vou precisar estudar mais para pegar o $6^{\circ}$ ano.

Uma das primeiras coisas que notamos é que o repertório matemático da professora B não lhe permitiu explicar a validade dos passos do algoritmo tradicional da divisão. Nesse sentido, o episódio reforça o que já foi discutido na seção 5.3.1. Sem um conhecimento profundo da matemática que ensinam, as professoras não podem, em muitos casos, provar para validar, para explicar ou comunicar - um resultado ou procedimento matemático. Menos ainda poderiam, com relação a tais tópicos, criar situações de validação para conduzir os alunos pelos caminhos da prova ou da argumentação em matemática. No caso citado, faltou à professora B conhecer de fato o algoritmo da divisão, mas também discernimento para distinguir uma explicação (uma prova com função explicativa, no sentido que propõe De Villiers) de uma descrição. Neste último aspecto, intervêm outros fatores, que não apenas o conhecimento ou a familiaridade com processos de prova. Um deles está ligado à autoridade docente e à autonomia intelectual esperada dos alunos. 
A situação descrita foi apenas uma simulação - não se tratava ali da real relação entre professora e aluna, mas entre professora e pesquisadora. Ainda assim, acreditamos que a professora $\mathrm{B}$ tenha aderido fortemente à dramatização. Nossa interpretação do evidente desconforto da professora pelo fato de ter sido questionada - e também da maneira como ela expressou esse desconforto - nos leva a inferir que a origem do incômodo estaria no modo como ela entendeu a pergunta “por que se faz assim?”. Sua reação sugere que ela encarou essa pergunta como um questionamento de sua autoridade docente. Se a professora diz que se faz assim, não seria lícito questioná-la. Entendemos que, a essa visão, novamente subjaz a concepção da prova apenas como forma de validação, e não de explicação - ainda que as próprias professoras provavelmente não descrevessem a situação nesses termos. A pergunta “por que é assim?” parece soar como desconfiança da palavra da professora, que, embora não explicitamente, responde algo como: "porque eu digo que funciona, e essa deve ser uma garantia". A validade deveria ser garantida pela autoridade. Se a pergunta "por que é assim?" fosse encarada como a expressão da necessidade intelectual de compreender as razões matemáticas por trás dos passos do algoritmo, o desconforto talvez fosse menor, mesmo na ausência dos conhecimentos necessários para fazer frente ao desafio.

Alguém poderia argumentar que o episódio descrito é fruto de idiossincrasias dos indivíduos em tela, tendo pouco valor no contexto de uma discussão mais ampla. Mas o modo como os professores entendem sua autoridade e como lidam com a autonomia intelectual dos alunos está fortemente atrelado ao tema da argumentação e da prova. Se a prova é vista apenas em sua função de validação e se a autoridade docente é considerada suficiente para validar toda a matemática discutida em sala de aula, então não haverá muito espaço para o desenvolvimento da capacidade dos alunos para argumentar em matemática. Num contexto como esse, a prova sempre parecerá desnecessária.

Neste ponto, retomamos Balacheff, que, com relação ao tema da prova, salienta a necessidade de focalizar um problema intrínseco ao contrato didático que naturalmente se estabelece entre professores e alunos.

O primeiro diagnóstico das possíveis fontes de dificuldade no ensino e na aprendizagem da prova matemática tem relação com a natureza do contrato didático mais natural que emerge das posições do aluno e do professor em relação a esse conhecimento. Uma vez que o professor é responsável por garantir a legitimidade e a validade epistemológica do que está sendo 
construído, segue-se que o aluno seria privado de um acesso autêntico à problematização da verdade e da prova ${ }^{19}$ (1999, tradução nossa).

Para o autor, a superação da dificuldade descrita exige que, durante a resolução de um problema, o professor restitua aos alunos sua responsabilidade matemática, de modo que possam tomar decisões e validar seus procedimentos e estratégias. No caso em tela, não há um problema proposto aos alunos, mas a discussão a respeito da forma de acolher dúvidas e questões propostas pelos alunos. Um trabalho em consonância com o desenvolvimento da argumentação em matemática exige respeitar e valorizar a autonomia intelectual dos alunos e, portanto, que o professor abra mão de sua autoridade como ferramenta de validação inquestionável em sala de aula.

\footnotetext{
19 "The first diagnosis of the possible sources of difficulty in the teaching and learning of mathematical proof to be proposed was the nature of the most natural didactical contract emerging from the positions of the student and the teacher with respect to the knowledge in question. Since the teacher is the guarantor of the legitimacy and epistemological validity of what is being constructed, it follows that the student would be deprived of an authentic access to a problématique of truth and proof" (BALACHEFF, 1999).
} 


\section{Conclusão}

$\mathrm{Na}$ Introdução deste trabalho, colocamo-nos seis questões de pesquisa, interrelacionadas, quais sejam:

1. Como os professores de matemática entendem a relação entre matemática e raciocínio lógico? Essa relação envolve, em alguma medida, as noções de argumentação e prova?

2. Como as demonstrações se relacionam com a constituição da ciência Matemática? A atividade matemática pode prescindir de processos de prova?

3. O que poderia dificultar que os professores de matemática da educação básica implementem um trabalho significativo com argumentação e prova na sala de aula?

4. Como se explica o aparente abandono do trabalho com argumentação e prova na matemática escolar brasileira das últimas décadas?

5. Que papéis a prova matemática pode desempenhar na matemática escolar?

6. O que distingue a prova matemática cabível na educação básica daquela praticada no ambiente acadêmico?

Para discutir essas questões, procedemos a duas investigações paralelas e complementares: uma pesquisa teórica e um estudo de caso. Ambas forneceram elementos importantes para elaborarmos possíveis respostas - certamente não exaustivas e passíveis de futuras revisões -, que desenvolvemos ao longo dos capítulos desta dissertação. Aqui, salientamo-las e tecemos as necessárias considerações complementares.

Quanto à primeira questão, a investigação de campo mostrou que as professoras participantes da pesquisa consideram o desenvolvimento do raciocínio lógico um dos principais objetivos da matemática escolar, embora sua compreensão do que é raciocínio lógico varie bastante. Mais do que isso, essa compreensão não necessariamente havia sido objeto de reflexão prévia das professoras, que, em diversos momentos da investigação, usaram a expressão de modo bastante vago para indicar sua crença de que o estudo da matemática desenvolve habilidades cognitivas as mais diversas.

A investigação também mostrou que essas professoras reconhecem a relação entre raciocínio lógico e processos de prova em matemática - se não espontaneamente, ao menos quando debatida explicitamente. Entretanto, esse reconhecimento se mostrou insuficiente para que as professoras valorizem atividades discentes envolvendo provas, de modo que esse tipo 
de atividade é secundário em seu trabalho. Além disso, de modo geral, as professoras tendem a explicitar a crença de que a elaboração de provas, ainda que informais, não é um objetivo de aprendizagem pertinente à educação básica.

Essa crença nos parece problemática por representar uma ruptura muito significativa entre a matemática escolar e a matemática acadêmica no que tange à prova matemática. Afinal, a investigação historiográfica empreendida no Capítulo 2 - respondendo à segunda questão listada - mostrou que a prova é basilar na atividade matemática. No desenvolvimento da Matemática como a ciência eminentemente dedutiva que conhecemos hoje, há contínuos processos dialéticos de refutações e provas, que levaram a um refinamento gradativo e não linear da noção de demonstração, agora fortemente pautada por ideais lógicos bastante rigorosos. Essa investigação também permitiu observar outras formas de prova matemática, distantes do ideal de rigor atual, mas importantes não apenas no contexto sociocultural dos episódios em que se inserem, mas também para a evolução do conhecimento matemático. Assim, ainda que com diferentes ênfases, formas e critérios de rigor, a prova tem sido historicamente uma das mais importantes práticas de produção e regulação do conhecimento matemático.

É interessante determo-nos nas justificativas centrais das professoras investigadas para seu posicionamento (no mínimo) reticente a respeito do trabalho com a prova matemática em sala de aula. Com isso, avançamos em direção a possíveis respostas à terceira questão. As professoras apontaram como dificuldades centrais para o trabalho com a prova matemática o tempo insuficiente e a defasagem de conhecimentos de boa parte de seus alunos.

De acordo com nossa experiência, a falta de tempo é uma queixa recorrente entre professores e pode se referir tanto à preparação de aulas, material de apoio, correção de atividades, registros diversos demandados pela gestão escolar etc. como ao tempo de aula, pois há muito a ensinar e uma carga horária insuficiente. A queixa das professoras pesquisadas parece referir-se principalmente ao segundo caso.

Escassa ou não, a carga horária destinada a uma disciplina escolar é invariavelmente limitada e, exatamente por isso, é, de fato, objeto de disputa entre diversas demandas e objetivos. Aquilo que o professor prioriza no tempo disponível é produto de diversos fatores, que incluem seus conhecimentos, suas crenças e suas concepções. Assim, entendemos que, quando alegam falta de tempo para trabalhar com a prova matemática na educação básica, em 
vez de justificar, parece-nos que as professoras só reforçam o pouco valor ou a não pertinência que atribuem a esse tipo de atividade.

A análise do material disponibilizado por uma das professoras ilustrou como, ao longo de um ano letivo, o tempo pode ser dedicado quase exclusivamente à compreensão e ao exercício de procedimentos rotineiros de resolução de equações e ao teorema de Pitágoras. Assim, é forçoso constatar que, em alguma medida, subjaz à prática dessa professora uma concepção tecnicista de ensino de matemática, que, dando prioridade a procedimentos rotineiros, realmente deixa pouco ou nenhum espaço à prova matemática.

Quando as professoras opõem a defasagem de conhecimentos de boa parte de seus alunos ao trabalho com a prova matemática, isso também revela alguma coisa sobre seus conhecimentos, crenças e concepções a tal respeito e também à forma como se ensina e aprende matemática.

É claro que, se boa parte dos alunos não sabe o que é esperado que se saiba em determinada série, isso é um complicador para o trabalho pedagógico e tende a reforçar a percepção da falta de tempo, dependendo dos recursos que o professor emprega para lidar com o problema. Mas, novamente, assim como com o tempo, essa justificativa é inespecífica, pois a elaboração de provas matemáticas informais poderia ser mais valorizada, a despeito da dificuldade de sua consecução num contexto educacional adverso.

Em nossa interpretação, essa justificativa reflete principalmente uma crença implícita de que a prova matemática é um assunto muito difícil para a educação básica, especial mas não exclusivamente em face da eventual defasagem do conhecimento dos alunos. Uma das professoras pesquisadas chegou a dizer que, de modo geral, os alunos não seriam capazes de fazer deduções. Provavelmente, essa crença se apoia numa concepção de a prova (designada aí com o termo dedução) que toma como referência as demonstrações formais que têm lugar no ambiente acadêmico.

As professoras citaram a falta de tempo e a defasagem dos alunos como fatores que dificultam - quando não impedem - propostas que demandam provas matemáticas na educação básica, mas a investigação de campo nos permitiu levantar outros aspectos problemáticos que elas não explicitaram e que se revelaram indiretamente. 
O fato de as provas matemáticas serem vistas como pouco importantes relaciona-se ao que De Villiers $(1990,2001)$ chamou de problema da necessidade da prova. Originalmente, o autor se refere ao fato de que, na educação básica, é comum que os alunos não percebam a necessidade de provar fatos matemáticos. No nosso caso, o problema da necessidade da prova está em outro nível - atinge os próprios educadores -, mas pode ser lido a partir das mesmas chaves. De Villiers localiza a origem desse problema na consideração limitada das diversas funções da prova. De fato, em nossa investigação de campo, notamos que, quando um professor vê a prova matemática apenas em sua função de convencimento, um possível efeito é que, mais que desnecessária, ela seja considerada um questionamento de sua autoridade docente.

Balacheff (1999) contribui para essa discussão destacando que o acesso do aluno à problemática da prova exige, em certa medida, a revisão do contrato didático geralmente vigente entre professores e alunos, em que os primeiros são os únicos responsáveis pela validação do conhecimento. Para o autor, é necessário que o professor planeje atividades com a finalidade de restituir aos alunos essa responsabilidade.

Outra possível dificuldade da implementação do ensino da prova matemática na educação básica liga-se a uma concepção que identifica a matemática com o produto de certa atividade humana, mais do que com a própria atividade. No estudo de caso, uma das professoras considera que deduzir um resultado ou tomar conhecimento dele são ações equivalentes, com vantagem para esta última, que demanda menos tempo. Isso mostra que, a despeito do discurso de valorização do desenvolvimento do raciocínio lógico, a atividade de deduzir não é vista como constitutiva da matemática e não é valorizada; o que realmente importa para essa professora é que o aluno tenha acesso ao produto da dedução.

Por fim, não podemos deixar de mencionar que, além de concepções e crenças desfavoráveis ao trabalho com a prova matemática na educação básica, o estudo de caso também evidenciou que os conhecimentos matemáticos das professoras nem sempre bastam para subsidiar esse tipo de trabalho. Observamos dificuldades com conteúdos matemáticos específicos e com noções de lógica elementar e, principalmente, pouca proficiência na elaboração de provas para resultados e procedimentos comuns da matemática escolar.

A despeito dessas dificuldades, verificamos que, pontualmente, a prova aparece na prática das professoras pesquisadas. Quando isso acontece, geralmente se trata de um 
momento expositivo da aula, em que a prova tem função explicativa. É o professor quem a executa, e sua apropriação pelos alunos não é o objetivo central.

As dificuldades arroladas até aqui centram-se na figura do professor, mas quais seriam os fatores mais amplos - políticos, sociais e culturais - que permeiam a prática docente no que tange à prova matemática? No Capítulo 3, examinamos alguns fatores que nos permitem esboçar uma resposta a nossa quarta questão.

Primeiramente, com a ajuda de Fiorentini (1995) e Pietropaolo (2005), rastreamos algumas tendências de ensino de Matemática que deixaram marcas importantes na história dessa disciplina escolar, pautando orientações curriculares, material didático e pesquisas educacionais. Essencialmente, procuramos verificar como passamos de um ensino formalista, vigente na primeira metade do século $\mathrm{XX}$ - em que as demonstrações tinham lugar de destaque - à situação atual. Constatamos que esse ensino formalista desconsiderava em grande medida o desenvolvimento cognitivo dos alunos e os objetivos próprios da educação, identificando-os com os objetivos da Matemática acadêmica. Nesse contexto, as demonstrações - nem sempre compreendidas, mas apenas reproduzidas - ficaram associadas a uma escola elitista e excludente, duramente criticada por movimentos posteriores.

Se muitas dessas críticas eram pertinentes e se muitas das tendências subsequentes propuseram alternativas para cultivar o raciocínio dedutivo respeitando a racionalidade em desenvolvimento dos educandos, outras tendências acabaram concorrendo para que o trabalho com a prova matemática saísse da cena da educação básica brasileira nas últimas décadas. É o caso do tecnicismo, que, especialmente em sua vertente mecanicista, suprime a necessidade da prova ao priorizar a execução de algoritmos, a memorização de definições e regras e a implementação de procedimentos padronizados para resolução de problemas-modelo. Para compreender melhor por que a prioridade a esse tipo de atividade suprime essa necessidade, vale lembrar a importância atribuída por Balacheff $(1987,1988)$ às situações de validação e de decisão, que efetivamente demandam a elaboração de provas ou a tomada de decisões.

Também examinamos o tratamento dado ao tema da prova matemática nos cursos de formação inicial de professores e numa das mais importantes referências curriculares das últimas décadas, os PCN.

Quanto aos cursos de formação inicial, notamos que a prova é tratada geralmente a partir de uma leitura técnica (GARNICA, 1996), perfeitamente adequada à prática dos 
matemáticos, mas insuficiente para ajudar o futuro professor a transpor esse assunto para a sala de aula. Nessa leitura técnica, que não distingue Matemática e matemática escolar, prioriza-se a função de validação da prova, e seu rigor deve ser o maior possível. Segundo Garnica, a leitura crítica da prova matemática já poderia mudar esse quadro, ensejando uma reflexão acerca da história da prova, dos pressupostos filosóficos que a sustentam e de suas diversas funções e formas de operação. Na visão do autor, a Educação Matemática tem um papel essencial, por ser o campo mais fecundo para essa leitura crítica.

Já a análise dos PCN mostrou que sua concepção de Matemática está em consonância com um trabalho robusto com argumentação e prova na educação básica, mas o documento não orienta o professor a implementar esse tipo de trabalho, por ser omisso com relação a muitos detalhamentos necessários. Por exemplo, não define objetivos claros do desenvolvimento da habilidade de elaborar provas matemáticas e, portanto, não discute estratégias para sua consecução, muito menos critérios para avaliar seus efeitos na formação dos alunos.

Em face desse quadro, entendemos que seriam necessárias ações em várias frentes para que a prova passe a ser vista pelos professores como pertinente ao contexto escolar e, assim, venha a ser trabalhada significativamente nas escolas brasileiras. A formação inicial e continuada de professores são duas das mais fundamentais dessas frentes. Nos cursos dedicados a professores de matemática (atuantes ou em formação), seria interessante abordar as possíveis funções da prova na escola e o que a distingue da praticada no ambiente acadêmico - temas que correspondem às duas últimas questões.

De acordo com a revisão bibliográfica, diversos referenciais teóricos - geralmente do campo da Educação Matemática - podem iluminar esses pontos. De Villiers (1990), por exemplo, arrola cinco diferentes funções da prova matemática: convencimento, explicação, descoberta, comunicação e sistematização. Nesse sentido, pelo menos as quatro primeiras seriam pertinentes ao contexto escolar.

Muitas vezes, no contexto escolar, em função do contrato didático vigente entre professores e alunos - e mesmo do que se estabelece entre escola e sociedade - o conhecimento está validado de plano. Assim, a função de convencimento da prova ("é verdade?") nem sempre é a mais importante na matemática escolar. Isso ocorrerá quando os alunos tiverem oportunidade de conjecturar e debater a validade de suas conjecturas. Em 
outros momentos, entretanto, a função de explicação (“por que é verdade?") pode se revelar muito mais significativa, respondendo a uma necessidade intelectual que deve ser cultivada.

Também as funções de descoberta e de comunicação da prova matemática são pertinentes ao universo escolar. Grosso modo, a primeira diz respeito à capacidade da prova de expor a estrutura de determinado objeto de estudo de modo a revelar resultados antes não suspeitados. Se não podem ser completamente controladas, essas descobertas são mais prováveis quando a prática de provar está estabelecida. A segunda é muito relevante no contexto escolar, podendo constituir o modo como alunos e professores se comunicam (oralmente ou por escrito) nas aulas de matemática, estimulando o debate e a metacognição.

Das funções da prova descritas por De Villiers, a única que talvez não seja pertinente ao contexto escolar é a de sistematização, que indica que a prova - e, mais especificamente, a demonstração - é o elo entre diferentes resultados de um mesma teoria ou entre diferentes teorias matemáticas. Essa é uma função muito mais evidente e relevante na Matemática acadêmica.

A diferença entre a prova matemática cabível na educação básica e aquela praticada na academia não se reduz às funções que ela pode desempenhar numa ou noutra. Enquanto na Matemática é um ponto de partida para a produção de conhecimento válido, na matemática escolar, em muitos sentidos, o rigor é uma meta que deve ser crescentemente valorizada. Assim, conceber diferentes tipos de prova, nem sempre tão rigorosas quanto as demonstrações da Matemática acadêmica, é importante para que os professores vislumbrem a viabilidade do assunto na educação básica.

Balacheff (1987, 1988), por exemplo, distingue provas pragmáticas e intelectuais e analisa profundamente os fatores que incidem na passagem entre essas duas categorias. Além disso, pontua entre elas diversos tipos mais específicos - todos cabíveis no contexto escolar: o empirismo ingênuo, o exemplo crucial, o exemplo genérico e o experimento intelectual. Esses tipos de prova se distinguem basicamente pelo tratamento dado à generalização, mas as possibilidades de execução de um tipo ou outro envolvem aspectos diversos: linguagem, conhecimentos mobilizados, características da situação etc.

Balacheff não é o único autor que pode auxiliar os professores a ampliarem sua concepção de prova para além das demonstrações da academia. Por exemplo, Sowder e Harel (1998) propõem outras tipologias que podem ser igualmente úteis. No Capítulo 1, fizemos 
uma análise comparativa entre a proposta desses autores e a de Balacheff, que não evidenciou contraposições, mas complementaridade.

Com isso, entendemos que nossas questões de pesquisa foram satisfatoriamente respondidas, dentro das limitações e do alcance de um trabalho de mestrado. Entretanto, como era de esperar, a investigação ensejou outras reflexões, que vão além das questões iniciais e que poderiam inspirar pesquisas futuras.

Uma dessas reflexões diz respeito à natureza das questões que nos colocamos inicialmente e ao tipo de trabalho que elas engendraram. Essas questões refletiram mais preocupação em compreender um cenário (“por quê?") do que em criar estratégias para modificá-lo (“como?”). Com isso, o trabalho acabou sendo mais explanatório que propositivo - algo talvez não muito usual num programa de mestrado profissional.

Entretanto, o aprofundamento teórico a que nos conduziu a pesquisa foi muito importante para nossa atuação como formadora de professores no CAEM-IME-USP. Em 2015, ao lado da prof ${ }^{a}$ Cláudia Cueva, ministramos um curso de atualização para professores de matemática da educação básica acerca do tema discutido. Mas, em face do caráter explanatório deste trabalho, o desenho do curso demandou transposições, adaptações e recursos os mais diversos.

Não incluímos aqui a descrição ou a análise desse curso por entender que ele deveria ser tomado como um estudo de caso, mas que isso não seria possível, já que o projeto OBEDUC o antecedeu. Por outro lado, acreditamos que os registros coletados poderiam ser a base de uma nova pesquisa sobre argumentação e prova, agora para responder a questões que conduziriam a um trabalho mais propositivo.

As demais reflexões desenvolvidas ao longo do trabalho deixam diversas pistas de aprofundamento que se poderiam seguir em pesquisas futuras. Uma delas diz respeito à relação entre a Educação Matemática e a Histórica da Matemática. No Capítulo 2, usamos os construtos teóricos de Balacheff $(1987,1988)$ para analisar a prova em alguns episódios tradicionais da História da Matemática. Já havíamos recorrido à História da Matemática para pensar a Educação Matemática, mas cumpre sublinhar quão frutífera pode ser a aplicação de referenciais da Educação Matemática à análise da História da Matemática. 
Também é interessante relacionar duas linhas de pesquisa da Educação Matemática: resolução de problemas e argumentação e prova.

Outro tema pouco explorado aqui e que merece atenção é o impacto dos softwares de geometria dinâmica na questão da prova matemática, sobre o qual temos vistos trabalhos interessantes.

Por fim, observamos que a argumentação e a prova permeiam não só a matemática, mas diversos outros campos, de modo que é possível traçar inúmeros paralelos e relações, de uma perspectiva inter ou transdisciplinar.

Finalmente, esperamos que este trabalho venha a ser útil aos leitores interessados. 


\section{Referências}

AABOE, A. Episódios da história antiga da matemática. Trad. João Pitombeira de Carvalho. Rio de Janeiro: SBM, 1984.

AGUILAR JÚNIOR, C. A.; NASSER, L. Analisando justificativas e argumentação matemática de alunos do ensino fundamental. Vidya, Santa Maria, v. 32, n. 2, p.133147, jul./dez. 2012.

ALMOULOUD, S. A. et al. Formação de professores de Matemática e apreensão significativa de problemas envolvendo provas e demonstrações. Educação Matemática Pesquisa, São Paulo, v. 10, n. 2, p. 217-243, 2008. Disponível em: $<$ http://revistas.pucsp.br/index.php/emp/article/view/1744/1135>. Acesso em: 5 fev. 2016.

ARSAC, G. L'origine de la démonstration: essai d'épistemologie didactique. Recherches en didactique des mathematiques, Grenoble, v. 8, n. 3, p. 267-312, 1987.

ASSIS JR., E. Square root of the square root of the square root.... Brilliant - Excel in math, science, and engineering. Disponível em: $<$ https://brilliant.org/problems/square-rootof-the-square-root-of-the-squareroot/?a=b\&utm_campaign=nux_email_10_11\&utm_medium $=$ email\&auto_login_key= QykH3IntLLc46HV26AzhVt27Bjv4rKzTpYRVy2CiMM\&utm_content=imageLink>. Acesso em: 25 set. 2015.

ÁVILA, G. Arquimedes, o rigor e o método. Matemática Universitária, Rio de Janeiro, n. 4, 1986.

BALACHEFF, N. Processus de Preuve et Situations de Validation. Educational Studies in Mathematics, 1987, v. 18, n. 2, p. 147-176. Disponível em:

$<$ http://link.springer.com/article/10.1007/BF00314724>. Acesso em: 5 fev. 2016.

. Une étude des processus de preuve en mathématique chez des élève de Collège. 1988. These (Doctorat ès-sciences didatiques des mathématiques) - Université Joseph Fourier - Grenoble 1, Institute National Polytechnique, Grenoble, 1988.

. Is argumentation an obstacle? Invitation to a debate... International Newsletter on the Teaching and Learning of Mathematical Proof, Mai/Jun 1999. Disponível em: $<$ http://www.lettredelapreuve.org/OldPreuve/Newsletter/990506Theme/990506Theme UK.html >. Acesso em: 3 set. 2015.

. The researcher epistemology: a deadlock for educational research on proof. Les cahiers du laboratoire Leibniz, Grenoble, n. 109, 2004.

. The role of the researcher's epistemology in mathematics education: an essay on the case of proof. ZDM Mathematics Education, v. 40, n. 3, ago. 2008. Disponível em: $<$ http://link.springer.com/article/10.1007/s11858-008-0103-2>. Acesso em: 5 fev. 2016.

BATISTA, I. L.; NAGAFUCHI, T. Um estudo histórico-filosófico acerca do papel das demonstrações em cursos de bacharelado em Matemática. Bolema, Rio Claro, v. 23, n. 37, p. 1081-1110, 2010. 
BLANCHÉ. R. A axiomática. Trad. Maria do Carmo Cary. Lisboa: Presença, 1987.

BOYER, C. B. História da Matemática. Trad. Elza F. Gomide. São Paulo: Edgar Blücher/EDUSP, 1974.

BRASIL. Secretaria de Educação Fundamental. Parâmetros curriculares nacionais: Matemática/Secretaria de Educação Fundamental. Brasília, DF: MEC/SEF, 1998.

COMISSÃO PERMANENTE DAS LICENCIATURAS. Programa de Formação de Professores - USP. São Paulo: Pró-Reitoria de Graduação da USP, 2004. Disponível em: <http://www4.fe.usp.br/wp-content/uploads/programa-de-formacao-deprofessores/programa-de-formacao-de-professores.pdf> Acesso em: 21 fev. 2016.

D’AMORE, B. Elementos de didática da matemática. Trad. Maria Cristina Bonomi. São Paulo: Livraria da Física, 2007.

DE VILLIERS, M. The role and function of proof in mathematics. Pythagoras, Durbanville, n. 24, p.17-24, 1990.

. Papel e funções da demonstração no trabalho com o Sketchpad. Revista Educação e Matemática, Lisboa, n. 63, p. 31-36, mar./abr. 2001.

DIEUDONNÉ, J. A formação da matemática contemporânea. Trad. J. F. von Hafe Perez. Lisboa: Dom Quixote, 1990.

DRUCK, I. F. Teorias axiomáticas de $\mathbf{1}^{\mathbf{a}}$ ordem. Notas de aula para a disciplina MPM5601 - Elementos de Lógica e Aplicações, 2013. Instituto de Matemática e Estatística da Universidade de São Paulo, 2013.

EVES, H. Introdução à história da matemática. Trad. Hygino H. Domingues. Campinas: Editora da UNICAMP, 1997.

FIORENTINI, D. Alguns modos de ver e conceber o ensino da Matemática no Brasil. Zetetiké, Campinas, v. 3, n. 4, p. 1-37, 1995.

GARNICA, Um ensaio sobre as concepções de professores de matemática: possibilidades metodológicas e um exercício de pesquisa. Educação e Pesquisa, São Paulo, v. 34, n. 3, p. 495-510, 2008.

GARNICA, A. V. Fascínio da técnica, declínio da crítica: um estudo sobre a prova rigorosa na formação do professor de matemática. Zetetiké, Campinas, v. 4, n. 5, p. 7-28, 1996.

HOUDEBINE, J. Demonstrer ou ne pas demontrer, voila la question. Repères IREM, Lyon, n. $1,1990$.

INEP. Matriz de avaliação de Matemática - PISA 2012. Brasília: INEP, 2013. Disponível em:

$<$ http://download.inep.gov.br/acoes_internacionais/pisa/marcos_referenciais/2013/mat riz_avaliacao_matematica.pdf>. Acesso em: 5 fev. 2016.

LÜDKE, M.; ANDRÉ, M. E. D. A. Pesquisa em educação: abordagens qualitativas. São Paulo: EPU, 1986. 
MACHADO, N. J. Matemática e realidade: análise dos pressupostos filosóficos que fundamentam o ensino da matemática. 5. ed. São Paulo: Cortez, 2001.

MOREIRA, P. C.; DAVID, M. M. M. S. A formação matemática do professor: licenciatura e prática docente escolar. Belo Horizonte: Autêntica, 2005. (Coleção Tendências em Educação Matemática.)

NASSER, L.; TINOCO, L. A. A. Argumentação e provas no ensino de matemática. Rio de Janeiro: UFRJ, 2001.

OECD. BRAZIL - Country Note - Results from PISA 2012. OCDE, 2013. Disponível em: < http://www.oecd.org/brazil/PISA-2012-results-brazil.pdf > . Acesso em: 5 fev. 2016.

PERRENOUD, P. A prática reflexiva no ofício de professor: profissionalização e razão pedagógica. Trad. Cláudia Schilling. Porto Alegre: Artmed, 2002.

PIETROPAOLO, R. (Re)significar as demonstrações nos currículos da educação básica e da formação de professores de matemática. 2005. Tese (Doutorado em Educação Matemática) - Pontifícia Universidade Católica de São Paulo, São Paulo, 2005.

PLANTIN, C. A argumentação: história, teorias, perspectivas. Trad. Marcos Marcionilo. São Paulo: Parábola, 2008.

PONTE, J. P. Concepções dos professores de matemática e processos de formação.

Departamento de Educação - Faculdade de Ciências, Lisboa, 1992. Disponível em: $<$ http://www.educ.fc.ul.pt/docentes/jponte/docs-pt/92-Ponte\%28Ericeira\%29.pdf>. Acesso: 20 maio 2016.

REID, D. A.; KNIPPING, C. Proof in Mathematics Education: research, learning and teaching. Rotterdam: Sense, 2010.

ROQUE, T. História da matemática: uma visão crítica, desfazendo mitos e lendas. Rio de Janeiro: Zahar, 2012.

SERRA, P. Retórica e argumentação. Notas de aula, 1995/1996. Universidade da Beira Interior, Covilhã, 1995. Disponível em: $<$ http://www.bocc.ubi.pt/pag/jpserra_retorica.pdf>. Acesso em: 5 fev. 2015.

SOWDER, L.; HAREL, G. Types of Students' Justifications. Mathematics Teacher, v. 91, n. 8, p. 670-675, 1998.

VILA, A.; CALLEJO, M. L. Matemática para aprender a pensar: o papel das crenças na resolução de problemas. Trad. Ernani Rosa. Porto Alegre: Artmed, 2006.

YIN. R. K. Estudo de caso: planejamento e método. Trad. Daniel Grassi. 2. ed. Porto Alegre: Bookman, 2001. 


\section{Apêndice - Questionário}

1. Identificação

Idade:

Sexo: $\square$ feminino $\square$ masculino

2. Atuação profisssional

a) Atualmente, leciona na rede:

$\square$ pública municipal $\square$ pública estadual $\quad \square$ particular $\quad \square$ outros

b) Em quais níveis e anos leciona atualmente?

$\square$ ed. infantil $\quad \square$ EF I $\quad \square 6^{\circ} / 7^{\circ}$ ano do EF II $\quad \square 8^{\circ} / 9^{\circ}$ ano do EF II

$\square$ EM $\square$ ens. superior $\quad \square$ outros

c) Cite brevemente a experiência profissional mais marcante na sua carreira de professor. (Indique instituição, nível escolar e duração da sua atuação.)

d) Qual seu nível de satisfação profissional atualmente?
$\square$ satisfeito
muito satisfeito
$\square$ insatisfeito
muito insatisfeito

Neste caso, qual é sua maior satisfação/insatisfação?

3. Formação

a) Como você avalia sua formação escolar anterior à faculdade (ensinos fundamental e médio)?

$\square$ fraca $\quad \square$ razoável $\square$ boa $\quad \square$ excelente

b) Explique brevemente porque optou pela profissão de professor.

c) Sobre sua graduação, indique:

a) Curso:

b) Instituição de ensino:

c) Ano de formação:

d) Fez alguma pós-graduação? Qual?

e) Sobre formação continuada, você:

$\square$ nunca participou de nenhuma atividade.

$\square$ participa apenas quando a escola convoca para esse tipo de atividade.

$\square$ já participou de cursos ou outros tipos de atividade por seu próprio interesse.

f) Você tem o hábito de ler sobre educação? Que tipo de leitura?

g) E sobre Matemática, você lê? Que tipo de leitura? 
h) Com que frequência você discute com seus colegas de profissão suas questões sobre ensino de Matemática?

$\square$ nunca $\quad \square$ raramente $\quad \square$ às vezes $\quad \square$ frequentemente

4. Concepções e prática

a) Compare as resoluções de dois alunos para o mesmo problema.

Problema: Um quartel vai usar ônibus com capacidade de 30 lugares para levar seus 350 soldados a uma cidade próxima. Quantos ônibus serão necessários?

Resolução do aluno 1

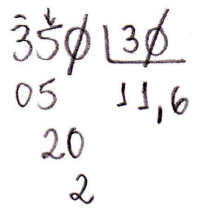

R: Aproximadamente 11,6 onibus
Resolução do aluno 2

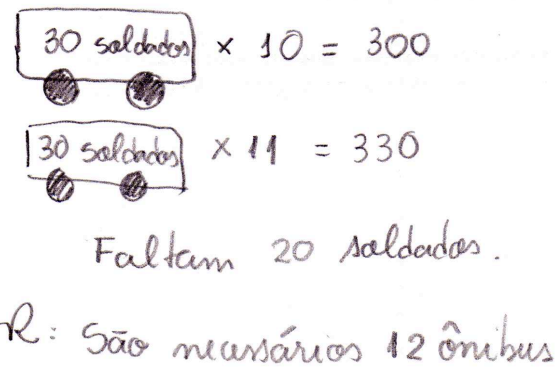

Em se tratando de uma avaliação e se esse problema valesse 1,0 ponto, que nota você atribuiria a cada um? Justifique sua resposta.

b) Considere a seguinte afirmação:

Somando dois números pares, sempre obtemos um número par.

Pede-se que um aluno de $6^{\circ}$ ano decida se a afirmação é falsa ou verdadeira e que justifique sua resposta. Como você espera que esse aluno responda à solicitação? E se fosse um aluno de $9^{\circ}$ ano? E você, como responderia a essa solicitação?

c) Com relação às justificativas das respostas dos alunos, assinale o que reflete sua prática de sala de aula.

\begin{tabular}{|c|c|c|c|c|}
\cline { 2 - 4 } \multicolumn{1}{c|}{} & Você não aceita & $\begin{array}{c}\text { Às vezes, você } \\
\text { aceita }\end{array}$ & $\begin{array}{c}\text { Você aceita } \\
\text { sempre }\end{array}$ & $\begin{array}{c}\text { Às vezes, você } \\
\text { mesma estimula } \\
\text { ou pede }\end{array}$ \\
\hline $\begin{array}{c}\text { Respostas sem } \\
\text { justificativa }\end{array}$ & & & \\
\hline $\begin{array}{c}\text { Exposição dos } \\
\text { cálculos como } \\
\text { justificativa }\end{array}$ & & & \\
\hline $\begin{array}{c}\text { Justificativas } \\
\text { discursivas (textos } \\
\text { escritos) }\end{array}$ & & & & \\
\hline $\begin{array}{c}\text { Justificativas por } \\
\text { meio de desenhos } \\
\text { ou esquemas }\end{array}$ & & & & \\
\hline
\end{tabular}

d) Suponha que você esteja aplicando o método prático para obtenção do MMC entre 10 e 15 na sua turma de $7^{\circ}$ ano e que um dos alunos lhe pergunte "por que funciona?". Como você responderia? 
e) Assinale 1, 2, 3, 4 ou 5 (vide legenda), indicando a frequência com que você propõe a seus alunos atividades em que é preciso:

\begin{tabular}{|l|l|l|l|l|l|}
\cline { 2 - 6 } \multicolumn{1}{l|}{} & (1) & (2) & (3) & (4) & (5) \\
\hline explicar como realizou um procedimento & & & & & \\
\hline decidir se uma afirmação é verdadeira ou falsa & & & & & \\
\hline justificar um procedimento ou decisão & & & & & \\
\hline elaborar conjecturas & & & & & \\
\hline representar algo por meio de desenhos ou esquemas & & & & & \\
\hline resolver problemas não estereotipados & & & & & \\
\hline fazer observações e registrá-las & & & & & \\
\hline comparar objetos, técnicas ou resoluções & & & & & \\
\hline classificar objetos matemáticos & & & & & \\
\hline definir um conceito com base em experiências anteriores & & & & & \\
\hline resumir ou sintetizar informações & & & & & \\
\hline
\end{tabular}
(1) nunca
(2) raramente
(3) às vezes
(4) frequentemente
(5) sempre

f) De alguma forma, você utiliza os PCN como referência para o seu trabalho de sala de aula? Comente e, se julgar adequado, cite outras referências que você utiliza.

g) Dentre os adjetivos listados, escolha e assinale os três (03) que melhor caracterizam um bom aluno em Matemática na sua opinião.
$\square$ rápido
organizado
$\square$ metódico
$\square$ reflexivo
$\square$ obediente
$\square$ concentrado
$\square$ rigoroso
$\square$ criativo

Outros:

h) Qual você acredita que seja a maior contribuição que o aprendizado da Matemática dá à formação geral do aluno? 